\title{
The effects of riparian tree harvest intensity and woody debris addition on biotic and abiotic stream characteristics
}

Jered Michael Studinski

West Virginia University

Follow this and additional works at: https://researchrepository.wvu.edu/etd

\section{Recommended Citation}

Studinski, Jered Michael, "The effects of riparian tree harvest intensity and woody debris addition on biotic and abiotic stream characteristics" (2010). Graduate Theses, Dissertations, and Problem Reports. 3112.

https://researchrepository.wvu.edu/etd/3112

This Dissertation is protected by copyright and/or related rights. It has been brought to you by the The Research Repository @ WVU with permission from the rights-holder(s). You are free to use this Dissertation in any way that is permitted by the copyright and related rights legislation that applies to your use. For other uses you must obtain permission from the rights-holder(s) directly, unless additional rights are indicated by a Creative Commons license in the record and/ or on the work itself. This Dissertation has been accepted for inclusion in WVU Graduate Theses, Dissertations, and Problem Reports collection by an authorized administrator of The Research Repository @ WVU.

For more information, please contact researchrepository@mail.wvu.edu. 
The effects of riparian tree harvest intensity and woody debris addition on biotic and abiotic stream characteristics

Jered Michael Studinski

Dissertation submitted to the

Davis College of Agriculture, Natural Resources and Design

at West Virginia University

in partial fulfillment of the requirements

for the degree of

Doctor of Philosophy

in

Forest Resources Science

Kyle J. Hartman, Ph.D., Chair

Ray Hicks, Ph.D.

Pat Keyser, Ph.D.

J. Todd Petty, Ph.D.

John Strazanac, Ph.D.

Division of Forestry and Natural Resources

Morgantown, West Virginia, 2010

Keywords: headwater stream, canopy, large woody debris, morphology, forestry, sedimentation, turbidity, periphyton, aquatic invertebrate, terrestrial invertebrate, brook trout, riparian 


\section{Abstract \\ The effect of riparian tree harvest intensity on biotic and abiotic stream characteristics}

\section{Jered Michael Studinski}

Forested headwater streams rely on riparian zones for many critical products and services. Riparian areas shade streams, stabilize stream banks, filter sediment, and provide allochthonous materials like leaves, large woody debris (LWD), and terrestrial invertebrates (TI's). Logging can affect the products and services of riparian zones. Best management practices (BMP's) have been developed to minimize the impacts of riparian timber harvest on streams. The main component of these guidelines is the establishment of a road-free riparian buffer called a streamside management zone (SMZ). The West Virginia Division of Forestry's BMP's require a SMZ that is at least $30 \mathrm{~m}$ wide for perennial and intermittent streams. There is no harvest limit within the SMZ, although heavy equipment cannot be operated within the area. This study quantified the effect of LWD additions and riparian tree harvest intensity at 50\% and $90 \%$ basal area harvest (BAH) on various biotic and abiotic characteristics of eight Appalachian headwater streams.

Stream temperatures and pool formation rates were affected by the treatments. Stream temperature increased as canopy cover decreased. During the warmest days in summer, water temperature within $90 \%$ BAH sections reached levels that could be stressful or lethal to salmonids. The combination of 50\% BAH sections and unharvested sections appeared to maintain natural thermal regimes. Neither the BAH nor the LWD treatments had an effect on stream turbidity or sedimentation rates within the experimental sections. The haphazard LWD additions resulted in no net increase in pool area. However, a greater number of pools were created and destroyed in the LWD addition sections. LWD additions also increased habitat complexity and most likely decreased the long-term LWD deficit that often occurs following logging operations.

Periphyton biomass increased with decreasing canopy coverage. Temperature and alkalinity did not significantly affect periphyton biomass, although the temperature gradient was small. Trends of increasing periphyton biomass were observed with canopy reductions as small as $6.4 \%$.

TI inputs, a critical food source for trout, were affected by the BAH treatments. TI input biomass was significantly higher in the $90 \%$ BAH sections. TI input composition varied significantly between years (natural variation) and between the reference and 90\% BAH sections. At greater harvest intensities, increases of Acrididae and Tettigoniidae (Orthoptera), wood-associated coleopterans, Formicidae (ants) and pollinating hymenopterans were observed.

Aquatic invertebrates (AI's) were, for the most part, unaffected by the treatments. AI abundance, richness, and biomass were not affected by the BAH or LWD treatments. AI abundance and biomass was significantly affected by natural annual variation. AI communities were not affected by the treatments, although a significant and more-direct relationship was observed between decreasing canopy coverage and increasing grazing taxa biomass. 
The results of this study suggest that riparian tree harvesting affects stream temperature, periphyton biomass, TI inputs, and to a lesser degree, AI's. Following riparian harvesting, AI and fish production may increase via increases in periphyton biomass and TI input biomass. However, observed increases in stream temperature created conditions that would have been metabolically and physiologically stressful for salmonids. Riparian zones with $50 \%$ BAH and alternating unharvested sections appears to minimize the thermal impacts of riparian tree harvesting. 


\section{Dedication}

This is dedicated to my family and friends. You are one in the same, and I love you all. 


\section{Acknowledgments}

I would like to thank my wife Holly for supporting me, tolerating me, and sharing the burden of my studies. I would also like to thank Dr. Kyle Hartman for the opportunity he gave me, and for all that he has done, from the technical lessons to the life lessons and everything between. I thank the rest of my committee, Dr. Ray Hicks, Dr. Pat Keyser, Dr. Todd Petty, and Dr. John Strazanac for their guidance and expertise.

I thank the best fisheries technician I have ever worked with, Bryan Olejasz. Without his tenacious work ethic and great attitude, I would still be emptying cat litter pans on Kittle Creek. I thank Donna Hartman, who was a tremendous resource with invertebrate identification. I would also like to thank people that have helped me in the field or lab: Jon Niles, Jason Stolarski, John Howell, George Merovich, Geoff Wiechert, Aleah Denney, Charlie Russell, John Neider, Garrett Staines, Andy Orsborn, Elijah Beyers, Aaron Nemeyer, and Aaron Plaugher.

Finally, I would like to thank the following for funding, support, and access: MeadWestvaco, US Forest Service, West Virginia University, and PennVirginia. 


\section{Table of Contents}

Chapter 1: Introduction to the impacts of logging on the functions of riparian areas in

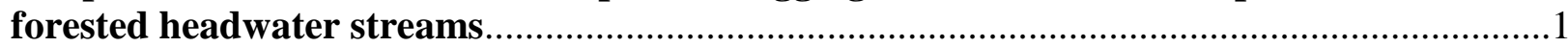

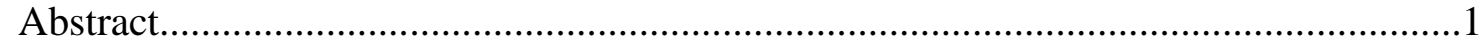

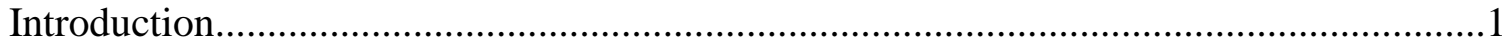

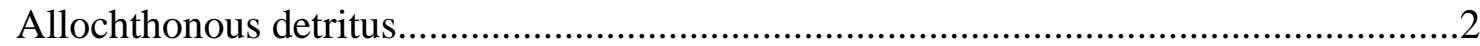

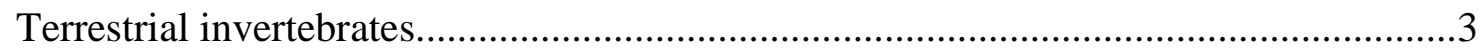

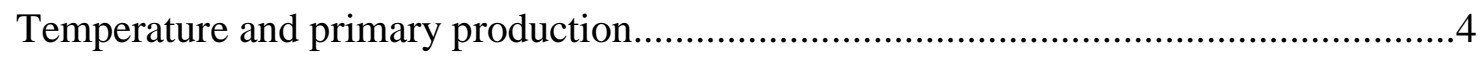

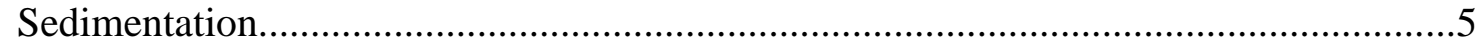

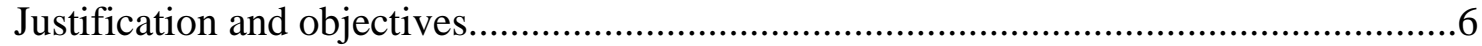

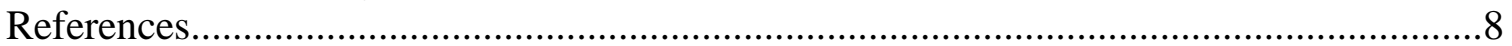

Chapter 2: The effects of riparian forestry practices and large woody debris additions on forested headwater stream temperature, sedimentation, and morphology ..........................12

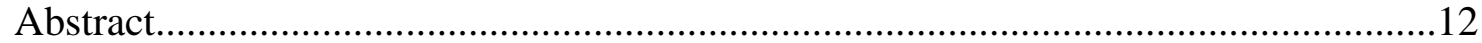

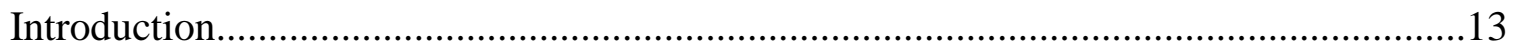

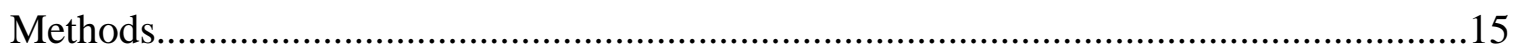

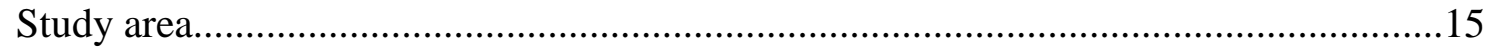

Canopy cover and temperature............................................................................17

Total suspended solids and sedimentation.............................................................18

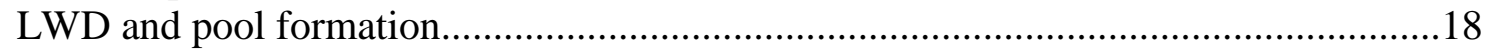

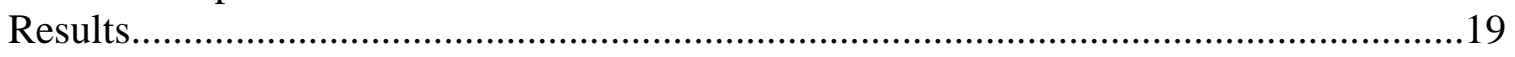

Canopy cover and temperature............................................................................19

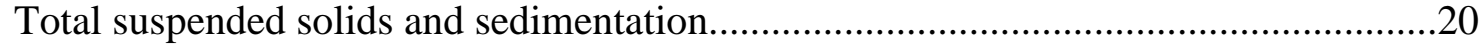

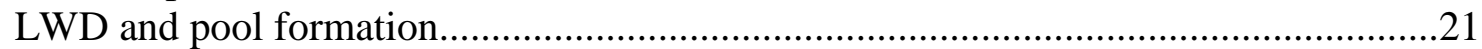

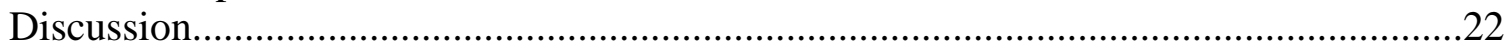

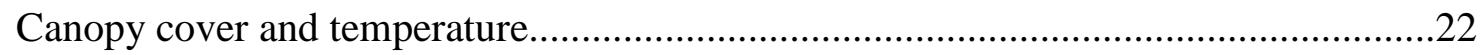

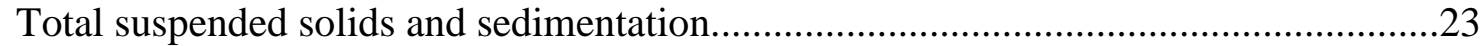

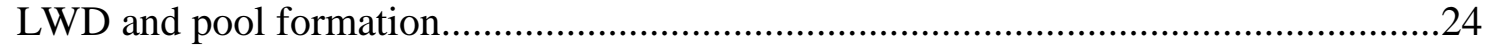

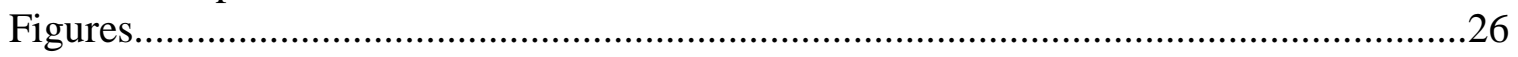

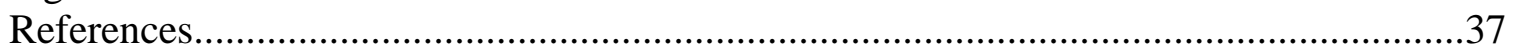

\section{Chapter 3: The effects of riparian forest harvest intensity on stream periphyton biomass}

.

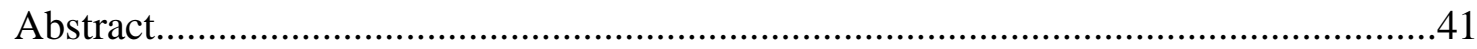

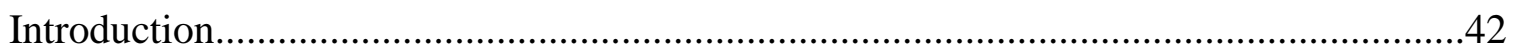

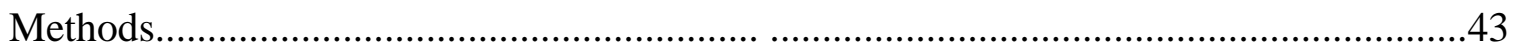

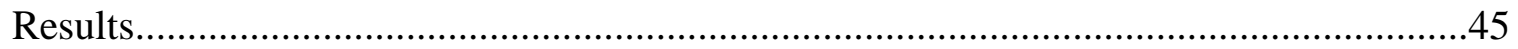

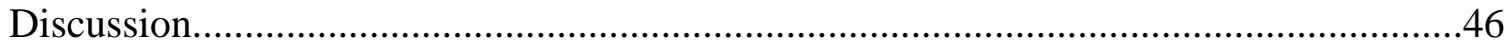

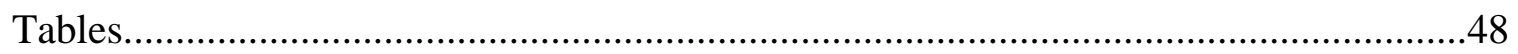

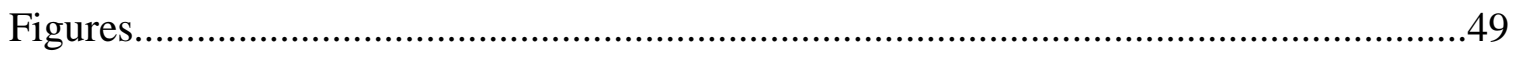

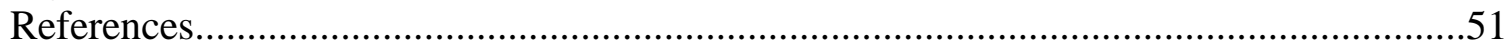


Chapter 4: The effects of riparian forest logging on terrestrial invertebrate inputs into forested headwater streams...........................................................................................53

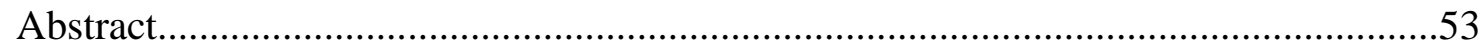

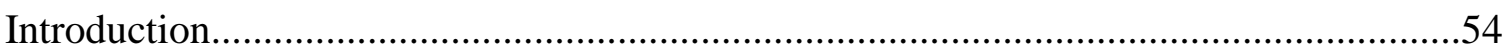

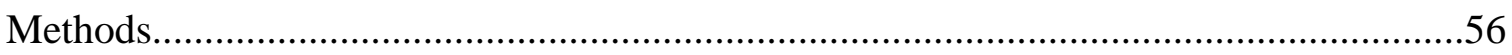

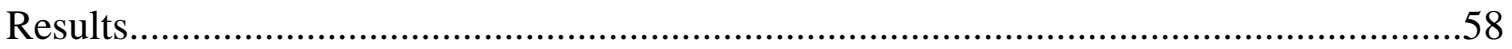

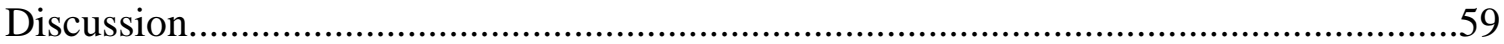

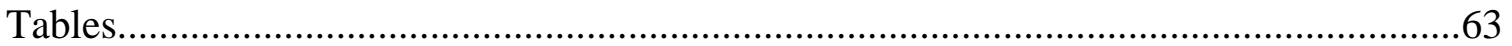

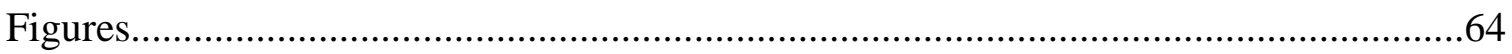

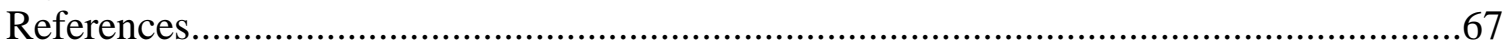

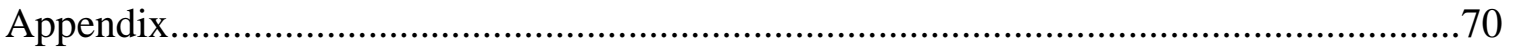

Chapter 5: The effects of riparian logging on aquatic invertebrates in forested headwater

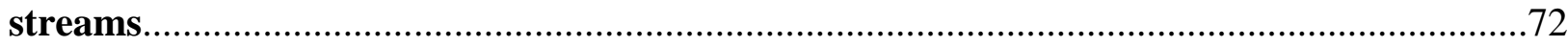

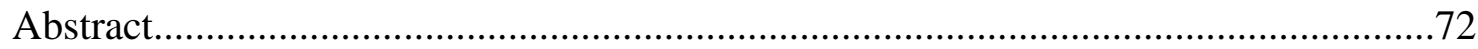

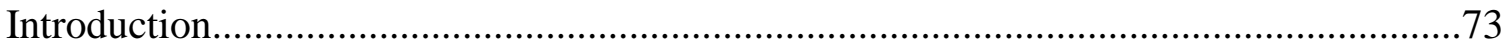

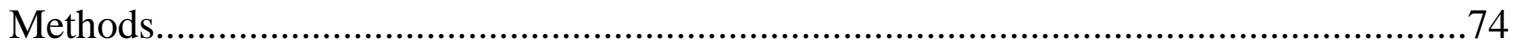

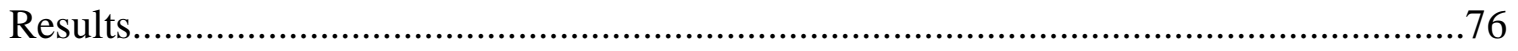

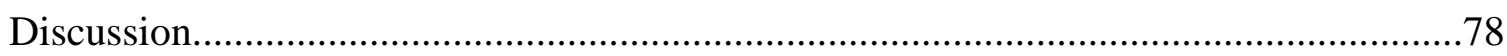

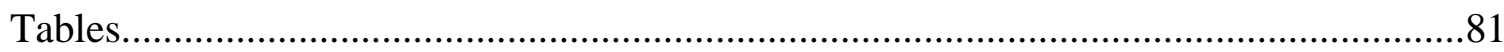

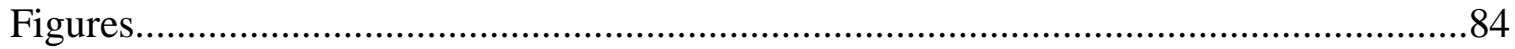

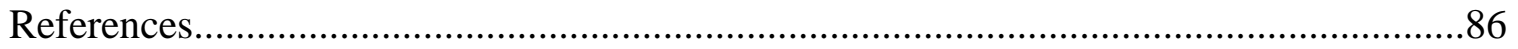

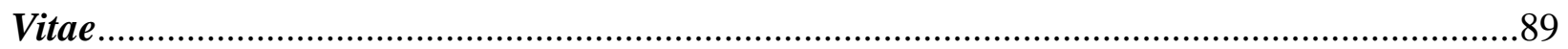


Chapter 1: Introduction to the impacts of logging on the functions of riparian areas in forested headwater streams

Jered M. Studinski

\begin{abstract}
Riparian zones act as buffers, stabilizers, and regulators of energy and nutrient flow into headwater streams. The conditions present in riparian areas structure stream food webs and contribute to the productivity of streams. Logging affects the products and services of the riparian areas which in turn impacts abiotic stream characteristics and stream biota. Stream response to riparian logging varies by region, and most likely is affected by latitude, aspect, elevation, and the intensity and size of the disturbance. Due to the regional applicability of riparian disturbance studies, research is especially important in areas with high timber harvesting and limited information assessing the impacts of riparian logging.
\end{abstract}

\title{
Introduction
}

Riparian zones exist at the interface between terrestrial and aquatic ecosystems. The boundaries of this interface are difficult to define, but the riparian zone can be conceptualized as a patchy area where the environmental variables are not as predictable or homogenous as its adjacent ecosystems (Naiman et al. 1988). This interface functions as a buffer and stabilizer (Keller and Swanson 1979; Naiman and Decamps 1997), a regulator of nutrient and energy flow (Naiman et al. 1988), and a source or sink for nutrients and organic matter (Edwards and Huryn 1995; Hering and Plachter 1997; Lowrance et al. 1986; Nakano and Murakami 2001; Sanzone et al. 
2003; Webster and Hartman 2005). Forested headwater streams in particular have strong interactions with their riparian zones, and the services and products of riparian areas can be reduced or altered by timber harvest.

\section{Allochthonous detritus}

The food web of forested streams is dependent on allochthonous energy inputs (Cummins et al. 1989; Vannote et al. 1980; Wallace et al. 1999), generally in the form of autumnal leaf fall. Dependence on allochthonous materials is strongest in headwater reaches and decreases as stream order increases (Vannote et al. 1980). Riparian harvest has been shown to decrease leaf litter inputs (Hetrick et al. 1998; Kreutzweiser et al. 2004). This decrease can exert strong bottom-up effects and lower the aquatic invertebrate (AI) productivity of a stream (Wallace et al. 1999). AI's that are classified as shredders are directly affected by reductions in litter inputs (Stone and Wallace 1998), and may decline following logging operations (Gurtz and Wallace 1984).

The riparian zone is the source of large woody debris (LWD) in streams. The incidental addition of slash during timber harvest may initially increase LWD in streams, but long-term natural inputs are greater in mature stands (Harmon et al. 1986; Silsbee and Larson 1983). LWD can enhance the retention of detritus and sediment by increasing pool area and creating physical obstructions (Bilby 1981; Bilby and Likens 1980; Hilderbrand et al. 1997; Muotka and Laasonen 2002; Raikow et al. 1995; Webster et al. 1994), although this function may be limited in high gradient systems (Hilderbrand et al. 1997). Increased retention of senesced leaves, often a limiting food source in streams (Dobson and Hildrew 1992), can improve stream productivity. 
LWD also stabilizes the stream bank (Keller and Swanson 1979), and in general, increases overall habitat complexity.

\section{Terrestrial invertebrates}

The Allen Paradox, which was based on the observation of fish production in a forested stream that was greater than the stream should seemingly support, has been researched for years (Allen 1951; Hynes 1970). Recent data indicate that terrestrial invertebrates (TI's) are an important food source for stream fishes, comprising 50\% or more of their diet during summer months (Allan et al. 2003; Cloe and Garman 1996; Kawaguchi and Nakano 2001; Sweka and Hartman 2008; Webster and Hartman 2005; Wipfli 1997). TI inputs decrease as stream order increases (Cloe and Garman 1996). Seasonally, TI inputs are highest in summer, a time when fish are under the greatest metabolic demands and streams have low standing crops of AI's (Cada et al. 1987b; Edwards and Huryn 1995; Kawaguchi and Nakano 2001; Nakano et al. 1999). Withinseason variation in TI inputs can be affected by air temperature and wind speed. The energy supplied by TI's may be critical to salmonids, especially in West Virginia where brook trout typically inhabit low-productivity streams and feed near maintenance ration (Cada et al. 1987b; Sweka and Hartman 2001; Utz and Hartman 2006). It appears the answer to Allen's Paradox is in the TI subsidy donated by the riparian area.

The importance of TI in stream food webs was elegantly demonstrated by Nakano et al. (1999), when they experimentally reduced TI inputs into a stream. The decrease of this food source resulted in increased consumption of AI's by salmonids. The population of grazing AI's, which are conspicuous and disproportionally preyed upon by stream salmonids (Cada et al. 1987a), were decimated, resulting in a periphyton bloom within the exclosure. This trophic 
cascade illustrated the importance of TI's, not only to salmonid production, but in structuring and balancing the stream food web.

Research investigating the effects of timber harvest on inputs of TI's into streams has failed to find consistent relationships. Edward and Huryn (1996) found that TI input composition depended upon land use, and grasslands had the highest input of TI biomass. Kawaguchi and Nakano (2001) found that TI input biomass was higher in forested areas than grasslands. Allan et al. (2003) and Wipfli (1997) found that forest age did not affect TI input biomass, while Batzer (2000) found increased TI inputs in recently harvested areas. Assuming that TI inputs reflect TI biomass (Nakano and Murakami 2001), knowledge of the effects of logging on TI communities could be integrated into stream management. TI responses to logging are also unclear. Researchers have observed increases (Greenberg and McGrane 1996) and decreases (Duguay et al. 2000) in TI abundance and biomass in disturbed areas. The TI response to logging may depend on size of disturbance and is partially related to other factors such as rainfall (Shure and Phillips 1991).

\section{Temperature and primary production}

Water temperature and primary production are regulated, in part, by riparian shading (Baillie et al. 2005; Davies and Nelson 1994; Hetrick et al. 1998; Kiffney et al. 2003; Quinn et al. 1997; Shortreed and Stockner 1983; Vannote et al. 1980). Riparian harvest has been linked to increased solar radiation and therefore higher stream temperatures, but the magnitude of this impact can be influenced by groundwater input (Moore et al. 2005). The effects of temperature on AI's vary by taxa, but it generally influences body size, survival, and development rates (Rempel and Carter 1987; Richardson 2008). Increased temperatures can increase growth rates, 
but when metabolic demands get too high, growth rates decrease and mortality increases. Heatintolerant taxa like plecopterans have very high mortalities above $20^{\circ} \mathrm{C}$ (Sweeney et al. 1986). Periphyton exhibits a positive response to increased solar radiation (Quinn et al. 1997), and coupled with other effects of riparian harvest, can lead to an increase in abundance of grazers and generalist feeders (Gurtz and Wallace 1984; Kiffney et al. 2003). Due to their conspicuous feeding location, grazers can be disproportionally preyed upon by stream salmonids (Cada et al. 1987a). Salmonids can dampen the grazer response to canopy thinning (Kishi et al. 2004; Quinn et al. 1997). The AI response to increased periphyton may be short-lived. Rapid regeneration of riparian vegetation can return AI communities to preharvest conditions within five years (Stone and Wallace 1998).

\section{Sedimentation}

Riparian zones can entrap and retain small particles, reducing sediment loads in streams (Lowrance et al. 1986; Pearce et al. 1998). The creation of roads and the disturbance of soil during forestry practices is a well-known source of in-stream sediment (Davies and Nelson 1994; Jones et al. 1999). Increased sediment loads can cause shifts in aquatic invertebrate communities, resulting in fewer Ephemeroptera, Plecoptera, and Trichoptera (EPT) taxa (Angradi 1999; Davies and Nelson 1994; Kaller and Hartman 2004). Increased sediment can limit primary productivity (Wood and Armitage 1997), increase AI drift from affected areas (Rosenberg and Wiens 1978), and bury AI eggs, resulting in dramatic reductions in reproductive success (Gleason et al. 2003). Sediment can also interfere with AI feeding and respiration (Wood and Armitage 1997). 


\section{Justification and objectives}

The forests of West Virginia underwent widespread clearcuts in the early $20^{\text {th }}$ century and are now facing another wave of timber harvest as the forests reach maturity. The steady demand for forest products and prevalence of headwater streams results in the inevitability of riparian logging.

Best management practices (BMP's) have been developed to minimize the impacts of riparian timber harvest on streams. Within the USA, guidelines and requirements vary by region and state (Lee et al. 2004). One component of these guidelines is the establishment of a streamside management zone (SMZ). The SMZ is a riparian buffer within which disturbance is limited. The West Virginia Division of Forestry's (WVDF) BMP's require a SMZ that is at least $30 \mathrm{~m}$ wide for perennial and intermittent streams and is road-free (West Virginia Division of Forestry 2005). Trees can be harvested from the SMZ (there is no harvest limit) but the operation of large equipment in this area is to be avoided. Following logging, proper reclamation techniques are to be applied, including seeding and mulching exposed soil. West Virginia BMP's require the removal of any LWD that may enter a stream during logging operations. The WVDF does, however, recognize that LWD is important in stream ecology (West Virginia Division of Forestry 2005).

Research on the effectiveness of different buffer widths has yielded promising results. Buffer widths $>30 \mathrm{~m}$ have been shown to decrease stream sedimentation (Davies and Nelson 1994). Streams with buffers $>30 \mathrm{~m}$ had AI communities similar to reference conditions, while buffers <30-m significantly changed communities (Newbold et al. 1980). However, Kiffney et al. (2003) found that 30-m buffers did not eliminate all forestry impacts. 
Studies on buffer effectiveness when logging is allowed within the buffer are limited, despite $80 \%$ of BMP's allowing some riparian harvest (Lee et al. 2004). Kochenderfer et al. (1997) concluded that West Virginia's BMP's effectively protect streams, and in their study buffers had a $44 \%$ basal area harvest (BAH). However, they observed significant increases in sediment transport following logging, and their in-stream thermometers did not record temperatures during critical low-water periods.

This project investigated the short term ecological effects of riparian logging at moderate and high intensities (50\% and 90\% BAH respectively), and the addition of LWD into streams. More specifically, the study's objectives were to:

1. Quantify the effects of riparian harvest and LWD additions on stream morphology, temperature, total suspended solids, and sedimentation rates.

2. Quantify the effects of riparian harvest on periphyton biomass.

3. Quantify the effects of riparian harvest on TI input biomass and composition.

4. Quantify the effects of riparian harvest and LWD additions on AI communities.

This study could be of utility to industrial and non-industrial landowners who want to maximize timber yields while maintaining or improving the products and services of riparian areas. 


\section{References}

Allan, J. D., M. S. Wipfli, J. P. Caouette, A. Prussian, and J. Rodgers. 2003. Influence of streamside vegetation on inputs of terrestrial invertebrates to salmonid food webs. Canadian Journal of Fisheries and Aquatic Sciences 60(3):309-320.

Allen, K. R. 1951. The Horokiwi stream: a study of a trout population. New Zealand Marine Department Fisheries Bulletin 10:1-231.

Angradi, T. R. 1999. Fine sediment and macroinvertebrate assemblages in Appalachian streams: A field experiment with biomonitoring applications. Journal of the North American Benthological Society 18(1):49-66.

Baillie, B. R., K. J. Collier, and J. Nagels. 2005. Effects of forest harvesting and woody debris removal on two Northland streams, New Zealand. New Zealand Journal of Marine and Freshwater Research 39:1-15.

Batzer, D. P., C. R. Jackson, and M. Mosner. 2000. Influences of riparian logging on plants and invertebrates in small, depressional wetlands of Georgia, U.S.A. Hydrobiologia 441(1):123-132.

Bilby, R. E. 1981. Role of organic debris dams in regulating the export of dissolved and particulate matter from a forested watershed. Ecology 62:1234-1243.

Bilby, R. E., and G. E. Likens. 1980. Importance of organic debris dams in the structure and function of stream ecosystems. Ecology 61:1107-1113.

Cada, G. F., J. M. Loar, and D. K. Cox. 1987a. Food and feeding preferences of rainbow and brown trout in southern Appalachian streams. American Midland Naturalist 117(2):374385.

Cada, G. F., J. M. Loar, and M. J. Sale. 1987b. Evidence of food limitation of rainbow and brown trout in southern Appalachian soft-water streams. Transactions of the American Fisheries Society 116(5):692-702.

Cloe, W. W., III, and G. C. Garman. 1996. The energetic importance of terrestrial arthropod inputs to three warm-water streams. Freshwater Biology 36(1):105-114.

Cummins, K. W., M. A. Wilzbach, D. M. Gates, J. B. Perry, and W. B. Taliaferro. 1989. Shredders and riparian vegetation. Bioscience 39(1):24-30.

Davies, P. E., and M. Nelson. 1994. Relationships between riparian buffer widths and the effects of logging on stream habitat, invertebrate community composition and fish abundance. Australian Journal of Marine and Freshwater Research 45(7):1289-1305.

Dobson, M., and A. G. Hildrew. 1992. A test of resource limitation among shredding detritivores in low order streams in southern England. Journal of Animal Ecology 61:69-77.

Duguay, J. P., P. B. Wood, and G. W. Miller. 2000. Effects of timber harvests on invertebrate biomass and avian nest success. Wildlife Society Bulletin 28(4):1123-1131.

Edwards, E. D., and A. D. Huryn. 1995. Annual contribution of terrestrial invertebrates to a New Zealand trout stream. New Zealand Journal of Marine and Freshwater Research 29(4):467-477.

Edwards, E. D., and A. D. Huryn. 1996. Effect of riparian land use on contributions of terrestrial invertebrates to streams. Hydrobiologia 337:1-3.

Gleason, R. A., N. H. Euliss, D. E. Hubbard, and W. G. Duffy. 2003. Effects of sediment load on emergence of aquatic invertebrates and plants from wetland soil egg and seed banks. Wetlands 23(1):26-34. 
Greenberg, C. H., and A. McGrane. 1996. A comparison of relative abundance and biomass of ground-dwelling arthropods under different forest management practices. Forest Ecology and Management 89:31-41.

Gurtz, M. E., and J. B. Wallace. 1984. Substrate-mediated response of stream invertebrates to disturbance. Ecology 65(5):1556-1569.

Harmon, M. E., and coauthors. 1986. Ecology of coarse woody debris in temperate ecosystems. Advances in Ecological Research 15:133-302.

Hering, D., and H. Plachter. 1997. Riparian ground beetles (Coleoptera, Carabidae) preying on aquatic invertebrates: a feeding strategy in alpine floodlands. Oecologia 111:261-270.

Hetrick, N. J., M. A. Brusven, W. R. Meehan, and T. C. Bjornn. 1998. Changes in solar input, water temperature, periphyton accumulation, and allochthonous input and storage after canopy removal along two small salmon streams in southeast Alaska. Transactions of the American Fisheries Society 127(6):859-875.

Hilderbrand, R. H., A. D. Lemly, C. A. Dolloff, and K. L. Harpster. 1997. Effects of large woody debris placement on stream channels and benthic macroinvertebrates. Canadian Journal of Fisheries and Aquatic Sciences 54(4):931-939.

Hynes, H. B. N. 1970. The Ecology of Running Waters. University of Toronto, Toronto.

Jones, E. B. D., III, G. S. Helfman, J. O. Harper, and P. V. Bolstad. 1999. Effects of riparian forest removal on fish assemblages in southern Appalachian streams. Conservation Biology 13(6):1454-1465.

Kaller, M., and K. Hartman. 2004. Evidence of a threshold level of fine sediment accumulation for altering benthic macroinvertebrate communities. Hydrobiologia 518:1-3.

Kawaguchi, Y., and S. Nakano. 2001. Contribution of terrestrial invertebrates to the annual resource budget for salmonids in forest and grassland reaches of a headwater stream. Freshwater Biology 46(3):303-316.

Keller, J. R., and F. J. Swanson. 1979. Effects of large organic material on channel form and fluvial processes. Earth Surface Processes 4:361-380.

Kiffney, P. M., J. S. Richardson, and J. P. Bull. 2003. Responses of periphyton and insects to experimental manipulation of riparian buffer width along forest streams. Journal of Applied Ecology 40(6):1060-1076.

Kishi, D., M. Murakami, S. Nakano, and Y. Taniguchi. 2004. Effects of forestry on the thermal habitat of Dolly Varden (Salvelinus malma). Ecological Research 19:283-290.

Kochenderfer, J. N., P. J. Edwards, and F. Wood. 1997. Hydrologic impacts of logging an Appalachian watershed using West Virginia's best management practices. Northern Journal of Applied Forestry 14:207-218.

Kreutzweiser, D. P., S. S. Capell, and F. D. Beall. 2004. Effects of selective forest harvesting on organic matter inputs and accumulation in headwater streams. Northern Journal of Applied Forestry 21(1):19-30.

Lee, P., C. Smyth, and S. Boutin. 2004. Quantitative review of riparian buffer width guidelines from Canada to the United States. Journal of Environmental Management 70:165-180.

Lowrance, R., J. K. Sharpe, and J. M. Sheridan. 1986. Long-term sediment deposition in the riparian zone of a coastal plain watershed. Journal of Soil and Water Conservation 41(4):266-271.

Moore, R., D. L. Spittlehouse, and A. Story. 2005. Riparian microclimate and stream temperature response to forest harvesting: a review. Journal of the American Water Resources Association 41(4):813-834. 
Muotka, T., and P. Laasonen. 2002. Ecosystem recovery in restored headwater streams: the role of enhanced leaf retention. Journal of Applied Ecology 39(1):145-156.

Naiman, R. J., and H. Decamps. 1997. The ecology of interfaces: riparian zones. Annual Review of Ecology and Systematics 28:621-658.

Naiman, R. J., H. Decamps, J. Pastor, and C. A. Johnston. 1988. The potential importance of boundaries to fluvial ecosystems. Journal of the North American Benthological Society 7(4):289-306.

Nakano, S., H. Miyasaka, and N. Kuhara. 1999. Terrestrial-aquatic linkages: riparian arthropod inputs alter trophic cascades in a stream food web. Ecology 80(7):2435-2441.

Nakano, S., and M. Murakami. 2001. Reciprocal subsidies: dynamic interdependence between terrestrial and aquatic food webs. Proceedings of the National Academy of Sciences, USA 98(1):166-170.

Newbold, J. D., D. C. Erman, and K. B. Roby. 1980. Effects of logging on macroinvertebrates in streams with and without buffer strips. Canadian Journal of Fisheries and Aquatic Sciences 37(7):1076-1085.

Pearce, R. A., and coauthors. 1998. Sediment filtration in a montane riparian zone under simulated rainfall. Journal of Range Management 51(3):309-314.

Quinn, J. M., A. B. Cooper, M. J. Stroud, and G. P. Burrell. 1997. Shade effects on stream periphyton and invertebrates: An experiment in streamside channels. New Zealand Journal of Marine and Freshwater Research 31(5):665-683.

Raikow, D. F., S. A. Grubbs, and K. W. Cummins. 1995. Debris dam dynamics and coarse particulate organic matter retention in an Appalachian mountain stream. Journal of the North American Benthological Society 14(4):535-546.

Rempel, R. S., and J. C. H. Carter. 1987. Temperature influences on adult size, development, and reproductive potential of aquatic Diptera. Canadian Journal of Fisheries and Aquatic Sciences 44(10):1743-1752.

Richardson, J. S. 2008. Aquatic arthropods and forestry: effects of large-scale land use on aquatic systems in Nearctic temperate regions. The Canadian Entomologist 104(4):495509.

Rosenberg, D. M., and A. P. Wiens. 1978. Effects of sediment addition on macrobenthic invertebrates in a Northern Canadian River. Water Research 12(10):753-763.

Sanzone, D. M., and coauthors. 2003. Carbon and nitrogen transfer from a desert stream to riparian predators. Oecologia 134(2):238-250.

Shortreed, K. S., and J. G. Stockner. 1983. Periphyton biomass and species composition in a coastal rain forest stream in British Columbia: effects of environmental changes caused by logging. Canadian Journal of Fisheries and Aquatic Sciences 40:1887-1895.

Shure, D. J., and D. L. Phillips. 1991. Patch size of forest openings and arthropod populations. Oecologia 86(3):325-334.

Silsbee, D. G., and G. L. Larson. 1983. A comparison of streams in logged and unlogged areas of Great Smoky Mountains National Park. Hydrobiologia 102(2):99-111.

Stone, M. K., and J. B. Wallace. 1998. Long-term recovery of a mountain stream from clear-cut logging: The effects of forest succession on benthic invertebrate community structure. Freshwater Biology 39(1):151-169.

Sweeney, B. W., R. L. Vannote, and P. J. Dodds. 1986. The relative importance of temperature and diet to larval development and adult size of the winter stonefly, Soyedina carolinensis (Plectoptera: Nemouridae). Freshwater Biology 16:39-48. 
Sweka, J. A., and K. J. Hartman. 2001. Fall and winter brook trout prey selection and daily ration. Source Proceedings of the Annual Conference of the Southeastern Association of Fish and Wildlife Agencies 55:8-22.

Sweka, J. A., and K. J. Hartman. 2008. Contribution of terrestrial invertebrates to yearly brook trout prey consumption and growth. Transactions of the American Fisheries Society 137(1):224-235.

Utz, R. M., and K. J. Hartman. 2006. Temporal and spatial variation in the energy intake of a brook trout (Salvelinus fontinalis) population in an Appalachian watershed. Canadian Journal of Fisheries and Aquatic Sciences 63(12):2675-2686.

Vannote, R. L., G. W. Minshall, K. W. Cummins, J. R. Sedell, and C. E. Cushing. 1980. The river continuum concept. Canadian Journal of Fisheries and Aquatic Sciences 37(1):130137.

Wallace, J. B., S. L. Eggert, and J. R. Webster. 1999. Effects of resource limitation on a detritalbased ecosystem. Ecological Monographs 69(4):409-442.

Webster, J. J., and K. J. Hartman. 2005. The role of terrestrial invertebrates in allopatric brook trout headwater streams in the central Appalachian Mountains. Journal of Freshwater Ecology 20(1):101-107.

Webster, J. R., A. P. Covich, J. L. Tank, and T. V. Crockett. 1994. Retention of coarse organic particles in streams in the Appalachian Mountains. Journal of the North American Benthological Society 13(2):140-150.

Wipfli, M. S. 1997. Terrestrial invertebrates as salmonid prey and nitrogen sources in streams: contrasting old-growth and young-growth riparian forests in southeastern Alaska, U.S.A. Canadian Journal of Fisheries and Aquatic Sciences 54(6):1259-1269.

Wood, P. J., and P. D. Armitage. 1997. Biological effects of fine sediment in the lotic environment. Environmental Management 21(2):203-217. 
Chapter 2: The effects of riparian forestry practices and large woody debris additions on forested headwater stream temperature, sedimentation, and morphology

\author{
Jered M. Studinski
}

\begin{abstract}
Forested headwater streams rely on their riparian areas for temperature regulation, large woody debris inputs, and sediment filtering. The products and services of riparian areas can be altered by timber harvest. To reduce the impacts of riparian timber harvest on streams, state agencies have developed various best management practices (BMP's). This study investigated the effects of riparian timber harvest in compliance with West Virginia BMP's at two harvest intensities $(50 \%$ and $90 \%$ basal area harvest $[\mathrm{BAH}])$. Additionally, trees were added about every eight meters to one treatment section/stream. The riparian manipulations occurred along eight streams in eastern West Virginia. Each stream had a lower treatment, upper treatment, and reference section. All sections were $250 \mathrm{~m}$ long and separated by a $100 \mathrm{~m}$ untreated section.

Water temperature increased in both the $50 \%$ and $90 \%$ BAH treatments (average of $0.18^{\circ} \mathrm{C}$ and $0.79^{\circ} \mathrm{C} / 100 \mathrm{~m}$, respectively). During the hottest days, streams with $90 \% \mathrm{BAH}$ removal treatments had water temperatures increase over $8^{\circ} \mathrm{C}$ as the stream flowed through the experimental sections (two $250 \mathrm{~m}$ treatments, separated by a $100 \mathrm{~m}$ unharvested section). After passing through a harvested section, water temperature decreased in the unharvested $100-\mathrm{m}$ sections at a rate of $-0.28^{\circ} \mathrm{C} / 100 \mathrm{~m}$. The $90 \%$ BAH treatments had the potential to disrupt fish and invertebrate communities via increased water temperature. New roads and log landings associated with the treatments had no effect on sedimentation and turbidity, possibly because
\end{abstract}


much of the watershed remained undisturbed. Large woody debris (LWD) additions increased habitat complexity but no net increase in pool area was observed. However, there was greater morphological instability within the LWD addition sections as pools were created and destroyed at significantly higher rates.

To minimize the effects of riparian logging, LWD additions and harvest limits of $50 \%$ BAH with alternating unharvested riparian sections are recommended. These recommendations would reduce the long-term LWD deficit that occurs following riparian timber harvesting, increase habitat complexity, and preserve thermal regimes.

\section{Introduction}

Riparian zones exist at the interface between terrestrial and aquatic ecosystems. The boundaries of this interface are difficult to define, but the riparian zone can be thought of as a patchy area where the environmental variables are not as predictable or homogenous as its adjacent ecosystems (Naiman et al. 1988). This interface regulates stream temperature, functions as a filter, buffer, and stabilizer (Keller and Swanson 1979; Naiman and Decamps 1997), and is the source of in-stream large woody debris (LWD). Forested headwater streams have particularly strong interactions with their riparian zones. The services and products of riparian areas can be altered or reduced by timber harvest (Davies and Nelson 1994).

Stream temperature can be affected by riparian logging intensity (Davies and Nelson 1994; De Groot et al. 2007; Hetrick et al. 1998; Moore et al. 2005), potentially excluding fish and changing aquatic invertebrate (AI) communities (Haggerty et al. 2004; Kishi et al. 2004). Cold-water taxa like plecopterans and brook trout (Salvelinus fontinalis) may be especially sensitive to increases in temperature (Sweeney et al. 1986). In eastern U.S.A., brook trout 
populations are declining due to a suite of factors, including acidification, invasion of exotic species, and habitat loss (Haines and Baker 1986; Larson and Moore 1985). Increases in stream temperatures impose a greater metabolic demand on brook trout (Hartman and Cox 2008), which typically occupy low-productivity streams and often feed at or near maintenance ration (Sweka and Hartman 2001b; Utz and Hartman 2006).

The riparian zone entraps and retains small particles, reducing sediment loads in streams (Lowrance et al. 1986; Pearce et al. 1998). Riparian tree harvesting has been linked to increased sedimentation and turbidity (Jones et al. 1999; Swank et al. 2001), mainly due to the building of roads and log landings (Kochenderfer et al. 1997). Increases in sediment loads can cause shifts in aquatic invertebrate communities (Wood and Armitage 1997), resulting in fewer Ephemeroptera, Plecoptera, and Trichoptera (EPT) taxa (Davies and Nelson 1994; Kaller and Hartman 2004). Brook trout have been shown to suffer from decreased growth as turbidity increases (Sweka and Hartman 2001a). Additionally, trout reproductive success has been positively correlated to streams with low levels of fine sediments (Hartman and Hakala 2006; Petty et al. 2005).

LWD improves detrital retention and increases habitat complexity, providing substrate for invertebrates and cover for fish (Bilby 1981; Bilby and Likens 1980; Hilderbrand et al. 1997). LWD is also a potential pool-forming mechanism (Bilby 1984; Gurnell et al. 1995; Trotter 1990), increasing the cold-water refugia that may be critical for over-summering brook trout. Older forests donate more LWD to streams than younger forests (Flebbe and Dolloff 1995; Richmond and Fausch 1995; Silsbee and Larson 1983) which suggests that logging creates long-term LWD deficits in streams. 
Best management practices (BMP's) have been developed to minimize the impacts of riparian timber harvest on streams. Within the USA, actual guidelines and requirements vary by region and state (Lee et al. 2004), but are generally similar in the establishment of a streamside management zone (SMZ). The SMZ is a riparian buffer within which disturbance is limited. West Virginia Division of Forestry (WVDF) BMP's require a road-free SMZ that extends at least $30 \mathrm{~m}$ from the stream bank for perennial and intermittent streams (West Virginia Division of Forestry 2005). Trees can be harvested from the SMZ as there is no harvest limit, but the operation of large equipment in this area is to be avoided. West Virginia BMP's require the removal of any LWD that may enter a stream during logging operations. However, the WVDF recognizes that LWD is important in stream ecology (West Virginia Division of Forestry 2005). Following logging, proper reclamation techniques are required, including seeding and mulching exposed soil.

This study's objectives were to quantify the effects of riparian tree harvesting at 50\% and 90\% basal area harvest (BAH) on stream temperature, sedimentation, and stream morphology. Additionally, the effects of LWD additions on sedimentation and stream morphology were investigated. This study could be of utility to industrial and non-industrial landowners who wish to maximize timber yields while maintaining or improving the products and services of riparian areas.

\section{Methods}

Study area

This study was conducted on eight headwater streams, all of which are tributaries of the Middle Fork River, in Randolph County, West Virginia. The streams are located on the Allegheny 
plateau at elevations of 705-868 m, with slopes of $2.2-5.5 \%$. The streams are surrounded by a mixed mesophytic forest (Van Sambeek et al. 2003) which was owned and managed for wood fiber production by MeadWestvaco Corporation, but subsequently was sold to PennVirginia Corporation during the study. The second-growth riparian forest was $65-80$ years old, and was dominated by black birch (Betula lenta), sugar maple (Acer saccharum), yellow birch (Betula alleghaniensis), and yellow poplar (Liriodendron tulipifera). All experimental streams flowed over poorly-buffered Pottsville geology. At the head of each stream, West Virginia Department of Natural Resources added limestone sand to increase buffering capacity. All streams contained resident brook trout populations.

The eight streams were divided into lower treatment, upper treatment, and reference sections, each being $250 \mathrm{~m}$ long (Figure 1). A 100-m stream segment with an untreated riparian area separated the sections. Streams were randomly and operationally assigned $50 \%$ or $90 \%$ BAH from the riparian zone. For this study, the riparian zone was defined as being within $30 \mathrm{~m}$ of the stream edge (the SMZ width required by West Virginia BMP's) regardless of slope or other variables.

To assess the effects of LWD additions on stream morphology and sedimentation, either the upper or lower treatment section of each stream was randomly assigned the addition of LWD. The assignment was constrained so that half of the sections with $50 \%$ or $90 \%$ BAH intensity had LWD added to the upstream treatment. During the harvest, loggers followed West Virginia BMP's in all sections except those requiring LWD additions, where they haphazardly felled whole trees into the stream approximately every eight meters. Riparian logging and LWD additions occurred July-December 2006, except on Kittle Creek, where treatments occurred in March 2007. 


\section{Canopy cover and temperature}

Canopy data was collected in the summers of 2007 and 2008 (1 and 2 years post-harvest) using a digital camera (Hewlett Packard model Q2190A, 85 maximum angle of view). At approximate 15-meter intervals, the canopy was photographed with the camera pointed directly upward, held 1.5 meters above the stream, and adjusted to the widest field-of-view. Using a custom black and white conversion in Photoshop (CS3 Extended version 10.0, Adobe Systems Incorporated), photographs were converted into binary images with branches and foliage black and sky and clouds white. The percent black pixels were recorded, yielding canopy coverage. Data from 2007 and 2008 were combined to form an average canopy cover for each section, and a KruskalWallis $\mathrm{H}$ test with post-hoc Mann Whitney U tests compared the treatments.

Temperature data was collected in summer 2008 (2 years post-harvest). A HOBO ${ }^{\circledR}$ Water Temp Pro data logger was fastened inside a section of white plastic pipe and anchored in a pool at the downstream and upstream edge of both treatment sections, and $250 \mathrm{~m}$ upstream from the top of the upper treatment section. Due to fiscal constraints the project was limited to 20 data loggers which had to be deployed in two events: four streams received data loggers in June and July, and four in August and September. Temperature was recorded hourly. Mean daily high temperature was calculated for each data logger location. Due to the loss and failure of some loggers and the resultant low sample sizes (in some cases, $n=2$ ), testing for differences between treatments was not practical. Regression analysis was used to test for a relationship between canopy cover and temperature increase. 


\section{Total suspended solids and sedimentation}

Water samples were collected from streams in spring and summer of 2007 and 2008 during a range of flows. At each stream, one liter of water was collected from the downstream edge of each section, and all sections were sampled within minutes of each other. The samples were then filtered through $0.7 \mu \mathrm{m}$ pore pre-dried and pre-weighed glass fiber filters using a hand pump. The filters were dried to a constant weight and weighed to the nearest $0.0001 \mathrm{~g}$. Repeated measures ANOVA was used to compare each treatment section to its corresponding reference section.

Sedimentation was quantified using substrate measurements in the summers of 2007 and 2008. Within each section, substrate diameter measurements were taken from 10 evenly spaced points along 10 transects throughout the section. Transects were perpendicular to stream flow. For each section, the median substrate size was calculated and compared to its reference, with data from 2007 and 2008 being averaged. Repeated measures ANOVA was used to compare the treatment sections to their corresponding references.

\section{LWD and pool formation}

LWD counts were conducted in summers of 2005 (pre-harvest), 2007, and 2008 (both postharvest). All LWD over $1 \mathrm{~m}$ in length, $10 \mathrm{~cm}$ in diameter and within the stream's bank-full boundary was placed into one of seven size categories (Richmond and Fausch 1995). LWD volume per section was calculated and compared over time and between treatments using twoway repeated measures ANOVA with pos hoc Wilcoxon signed-ranks tests.

Stream morphology was surveyed in summers of 2005, 2007, and 2008 during base flow conditions. Each habitat unit (i.e. pool, riffle, run) had three width measurements, three depth 
measurements along each width measurement, and a length measurement (Dolloff et al. 1997). The maximum depth of pools was measured. Two-way repeated measures ANOVA was used to compare the average maximum pool depth of each section to its corresponding reference before and after the riparian harvest. Pool area was calculated and compared over time and between treatments using two-way repeated measures ANOVA. Additionally, a simple instability index was created. This consisted of a proportional linear measure of change in habitat classification, calculated for each section. For example, if within a 250-m experimental section a 4.3-m pool was filled in and became a riffle and a 5.7-m pool was created from another riffle, that section would have $10.0 \mathrm{~m}$ of instability, or proportionally, 0.04 . The instability index is essentially a linear measure of pools created and destroyed. Instability was calculated between the 2005 and 2008 surveys. Treatments were compared to their references using repeated measures ANOVA with post-hoc tests. All statistical analyses were performed in Program R (R Development Core Team 2009).

\section{Results}

\section{Canopy cover and temperature}

The treatments of $0 \%, 50 \%$, and $90 \% \mathrm{BAH}$ produced 3 distinct groups of canopy coverage (Kruskal-Wallis $\mathrm{p}<0.001$ [Figure 2]). Post-hoc Mann-Whitney U tests indicated each treatment was different from the others ( $\mathrm{p}$-value range: $<0.001-0.005)$. The variation in canopy coverage for the $90 \%$ removal treatments was due in part to the lack of harvest in steep, inaccessible riparian areas.

Canopy cover played a role in stream warming and temperature fluctuations. When stream temperatures were at their daily maxima, longitudinal water temperature change appeared 
negligible in the uncut areas upstream of all treatments (Figure 3). Comparisons between stream sections were made during the hour in which the lowest section had the warmest water. Streams' temperatures increased as water flowed through both the $50 \%$ and $90 \% \mathrm{BAH}$ treatments $\left(0.18^{\circ} \mathrm{C}\right.$ and $0.79^{\circ} \mathrm{C} / 100 \mathrm{~m}$, respectively). After passing through the upstream treatment sections, stream temperature decreased in the $100-\mathrm{m}$ unharvested sections (average of $-0.28^{\circ} \mathrm{C} / 100 \mathrm{~m}$ ). After passing through both $250-\mathrm{m}$ treatment sections and the $100-\mathrm{m}$ unharvested section, the stream temperatures had increased $0.5^{\circ} \mathrm{C}$ and $3.7^{\circ} \mathrm{C}$ in the $50 \%$ and $90 \% \mathrm{BAH}$ treatments, respectively (Figure 3). Mean daily maximum temperatures in the downstream treatment sections of the streams was $15.9-18.0^{\circ} \mathrm{C}$ in the $50 \% \mathrm{BAH}$ treatments and $17.2-20.4^{\circ} \mathrm{C}$ in the $90 \% \mathrm{BAH}$ treatments.

Using hourly temperature data, high temperature extremes appeared more pronounced in the $90 \%$ BAH sections than in the 50\% BAH sections (Figures 4, 5). During the hottest days, the $90 \%$ BAH sections occasionally reached temperatures $>24.0^{\circ} \mathrm{C}$ (Figures 4,5 ), and at times with $>8.0^{\circ} \mathrm{C}$ increases from the reference section to the bottom of the downstream treatment. Regression analysis indicated a relationship between stream temperature change and canopy cover (Figure 6). As canopy cover increased, change in temperature $\left({ }^{\circ} \mathrm{C}\right.$ per $\left.100 \mathrm{~m}\right)$ decreased $\left(\mathrm{p}<0.001, \mathrm{r}^{2}=0.49\right)$.

\section{Total suspended solids and sedimentation}

The treatments had no effect on stream turbidity and sedimentation within the study reach. Repeated measures ANOVA found no differences in TSS between the treatment sections and their corresponding reference sections $(50 \% \mathrm{BAH} \mathrm{p}=0.835,90 \% \mathrm{BAH} \mathrm{p}=0.258$ [Figure 7]). 
Median substrate size for each of the treatments did not differ from their corresponding references $(50 \%$ BAH $\mathrm{p}=0.413,90 \%$ BAH $\mathrm{p}=0.184$ [Figure 8]).

\section{LWD and pool formation}

As expected, LWD greatly increased in the LWD addition sections. Two-way repeated measures ANOVA reported a significant treatment effect (treatment $\mathrm{x}$ year interaction $\mathrm{p}=0.015$ [Figure 9]). Post-hoc tests indicated LWD volume was greater in the LWD addition sections compared to the corresponding reference sections in 2007 and 2008 ( $\mathrm{p}=0.025$ for both). LWD volumes were not significantly higher than their corresponding reference sections in the logged-only (no LWD addition) sections in 2007 or 2008 ( $\mathrm{p}=0.093, \mathrm{p}=0.401$, respectively). In the two years following the treatments, some in-stream LWD formed large debris dams, and in one case, rerouted a stream down a new channel for approximately $80 \mathrm{~m}$. In the four instances where the LWD addition section was in the upstream treatment, only once did LWD also increase in the downstream 100-m unlogged section.

Pool area did not change in response to the LWD treatments (treatment $\mathrm{x}$ year interaction $\mathrm{p}=0.942$ [Figure 10]). However, the instability index, which compared cumulative linear change (2005 with 2008), indicated differences between the treatments ( $\mathrm{p}=0.021$ [Figure 11]). Post hoc tests determined that the instability in the LWD addition sections was higher than in both the reference and harvest-only sections $(\mathrm{p}=0.016$ and $\mathrm{p}=0.017$, respectively). The treatments did not have an effect on average maximum pool depth (treatment $\mathrm{x}$ year interaction $\mathrm{p}=0.546$ ). 


\section{Discussion}

\section{Canopy cover and temperature}

The BAH treatments and the resultant canopy thinning had fairly consistent effects on stream temperature, although the relationship was less-consistent at lower canopy coverage. Had the treatments been extended beyond $250 \mathrm{~m}$, a nonlinear relationship would likely have been observed (Moore et al. 2005) which limits the extrapolation of these data. The slopes of the within-stream and the overall temperature/canopy relationships are dependent on stream size, aspect, groundwater dynamics, and climate (Moore et al. 2005), making regional comparisons difficult. Despite these caveats, this study's observations fall within the wide range of changes observed or predicted in other regions (Davies and Nelson 1994; Moore et al. 2005; Sugimoto et al. 1997).

Stream temperature increases in the $90 \%$ BAH sections may have been severe enough to stress and displace stream biota. Brook trout prefer temperatures under $16^{\circ} \mathrm{C}$, above which growth rates decrease (McCormick et al. 1972; Meehan and Bjornn 1991). Mortality increases at temperatures above $18^{\circ} \mathrm{C}$ (Peterson et al. 1979), and the upper lethal limit for brook trout is approximately $25^{\circ} \mathrm{C}$ (Hynes 1970; McCormick et al. 1972; Power 1980). Increases in temperature, when coupled with acidic, low productivity streams, may be especially harmful. Coldwater refugia would be important within the $90 \%$ BAH sections. Although the data loggers were placed in pools, it is possible that brook trout could find cooler refugia within the treatment sections (i.e. deeper pools or pools with greater groundwater influence), or migrate out of the sections. However, it is likely that portions of $90 \%$ BAH sections were at least temporarily reduced in habitat quality for brook trout due to high temperatures. 
The impact of temperature increases on aquatic macroinvertebrates is difficult to predict. Sweeny et al. (1986) found that a consistent temperature of $15^{\circ} \mathrm{C}$ was fatal to some plecopterans, and that decreased growth was observed when water was warmed $3{ }^{\circ} \mathrm{C}$ over ambient stream temperature. Aquatic macroinvertebrate density may be positively correlated with temperature (Kreutzweiser et al. 2005), although the effects of temperature are difficult to separate from the often-simultaneous effects of decreased allochthonous inputs and increased primary production. Considering this suite of factors, a decrease in abundance and evenness and a shift from EPT taxa to dipterans is usually observed (Davies and Nelson 1994; Kiffney et al. 2003).

Riparian harvest intensities $>50 \% \mathrm{BAH}$ (resulting in $<65 \%$ canopy coverage) appear to increase stream temperatures and have the potential to be harmful to a stream's biota. Unlogged riparian sections have a cooling effect on a stream, and may be a useful tool in maintaining a more-natural temperature regime.

\section{Total suspended solids and sedimentation}

Following riparian logging, the streams did not appear to suffer from increased TSS or sedimentation rates, although these data should be interpreted with caution. Low sample sizes and undisturbed watersheds complicate the results. Unlike a normal logging operation, these treatments extended only $30 \mathrm{~m}$ from the stream, leaving the rest of the watershed relatively undisturbed. Most sedimentation is the result of building roads and log landings (Kochenderfer et al. 1997; Kreutzweiser and Capell 2001), which was minimal since only a limited area of the watershed was logged. Thus, these data do not represent the cumulative impacts of watershedwide logging operations. 


\section{LWD and pool formation}

While the LWD additions were substantial, there was no net gain in pool area or maximum depth. The results were similar to other LWD addition projects in high-gradient streams (Hilderbrand et al. 1997; Sweka and Hartman 2006). However, pools were created and destroyed at higher rates in the LWD treatment sections. Stream morphologies are generally at dynamic equilibrium, which is dependent upon factors such as flow, slope, and substrate size (Chih 1971; Leopold et al. 1964). Although the addition of LWD in this study used an operationally-realistic haphazard approach, there is evidence from other studies that suggest careful placement of LWD may increase pool area above a stream's equilibrium (Hilderbrand et al. 1997). LWD, even when not associated with pool creation, has a positive effect on fish and invertebrates (Flebbe and Dolloff 1995; Gurnell et al. 1995; Hernanadez et al. 2005; Rosenfeld et al. 2000). This study's copious LWD additions improved habitat complexity within pools and riffles, and many small pools (undetectable to the stream survey methods) were created (personal observation).

LWD additions reduce the long-term LWD deficit that occurs in streams following logging (Flebbe and Dolloff 1995; Silsbee and Larson 1983) and increases habitat complexity. Due to its simplicity, haphazard LWD additions are recommended while avoiding the creation of channel spanners. Limiting the LWD additions to whole trees and tree tops should make downstream transport less likely and may reduce the hazards associated with in-stream LWD movement, such as clogged culverts and scoured streambeds. 


\section{Conclusions}

The results of this study are likely applicable to other forested, low-order streams with similar slopes, climate, and forest type. Current West Virginia BMP's can be modified to further protect stream habitat. LWD additions reduce the long-term LWD deficits and improve habitat complexity. The felling of whole trees into streams should be encouraged, although rates above those used in this study (one tree per eight meters) may be excessive. Additionally, SMZ's with $250 \mathrm{~m}$ of $50 \%$ BAH followed by $100 \mathrm{~m}$ of unharvested SMZ appeared to reduce thermal impacts. It is recommended that SMZ's have alternating harvested and unharvested sections. Where SMZ harvest is allowed, it should be limited to $50 \% \mathrm{BAH}$. 


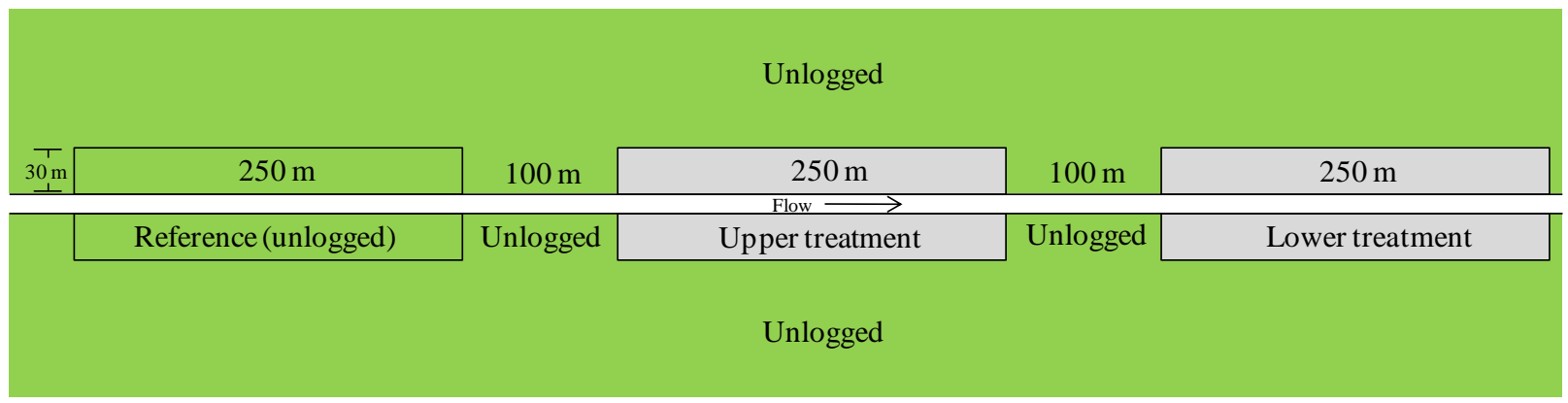

Figure 1. Logging treatment design along the eight streams. Four streams received 50\% basal removal and four $90 \%$ basal removal. Each stream received LWD additions in one of the treatment sections. 


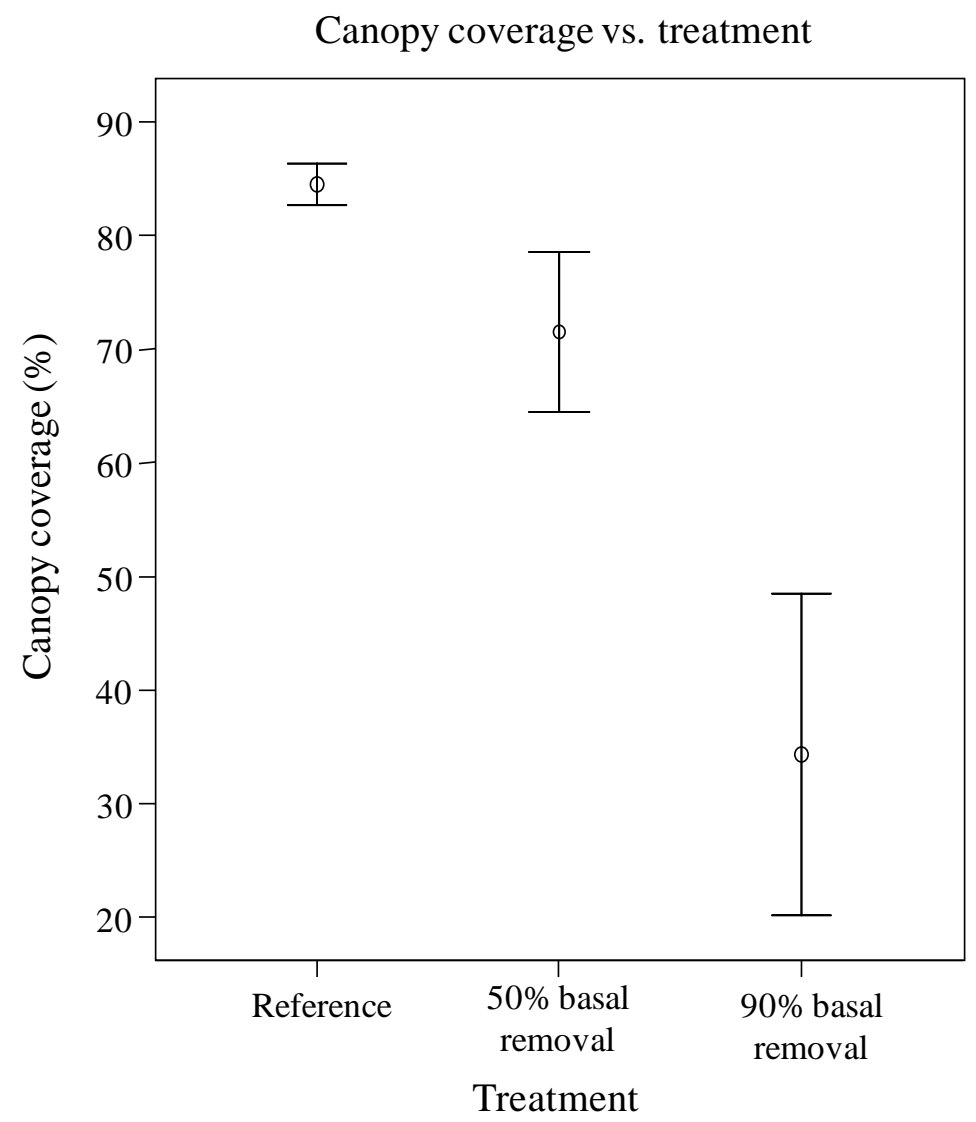

Figure 2. Basal removal treatment effects on canopy coverage. Symbols represent mean values with $95 \%$ confidence intervals. Each treatment type was significantly different from the others (post hoc pairwise comparisions p-value range $=<0.001-0.005$ ) 


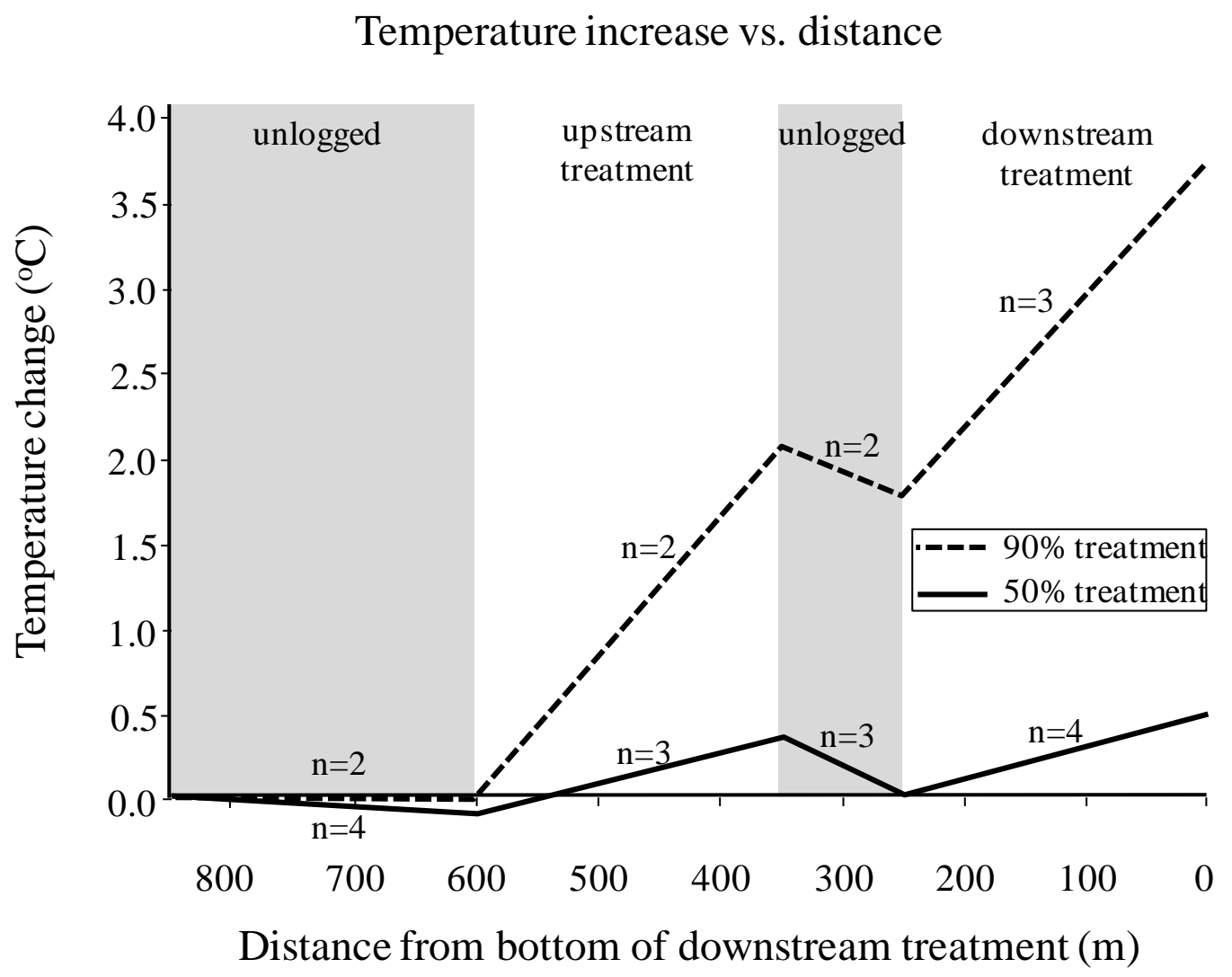

Figure 3. Cumulative temperature change as water flowed through unlogged and logged sections of headwater streams. Differences were calculated from daily high temperatures over a onemonth period during summer. The "n" denotes the number of stream sections from which the mean increases were calculated. 

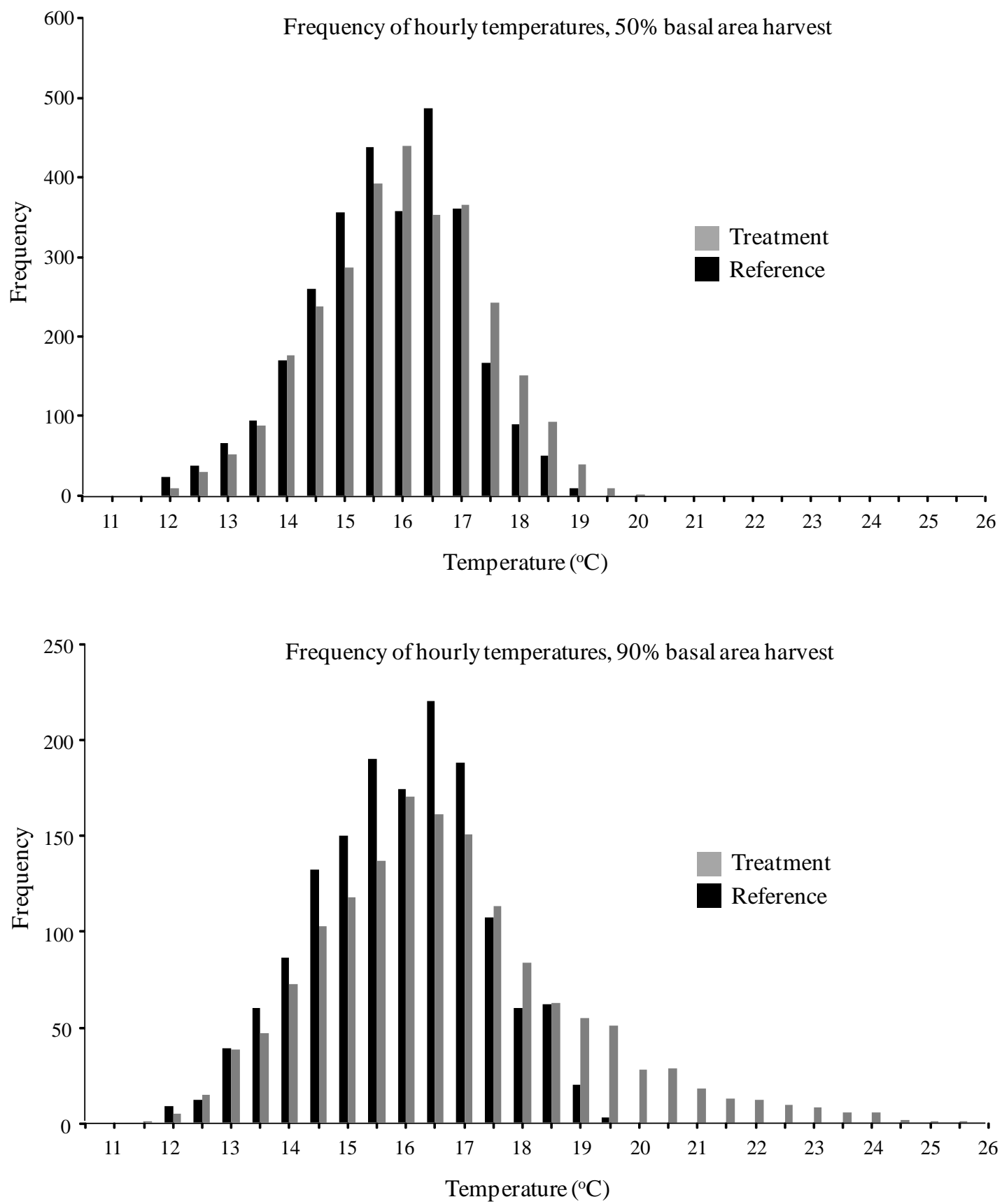

Figure 4. Frequencies of hourly temperatures of reference and treatment sections (50\% and 90\% basal area removal) in Appalachian headwater streams. Data were combined from two sampling events in summer, 2008. Data were scaled so the reference and treatment sections had a similar number of observations. 


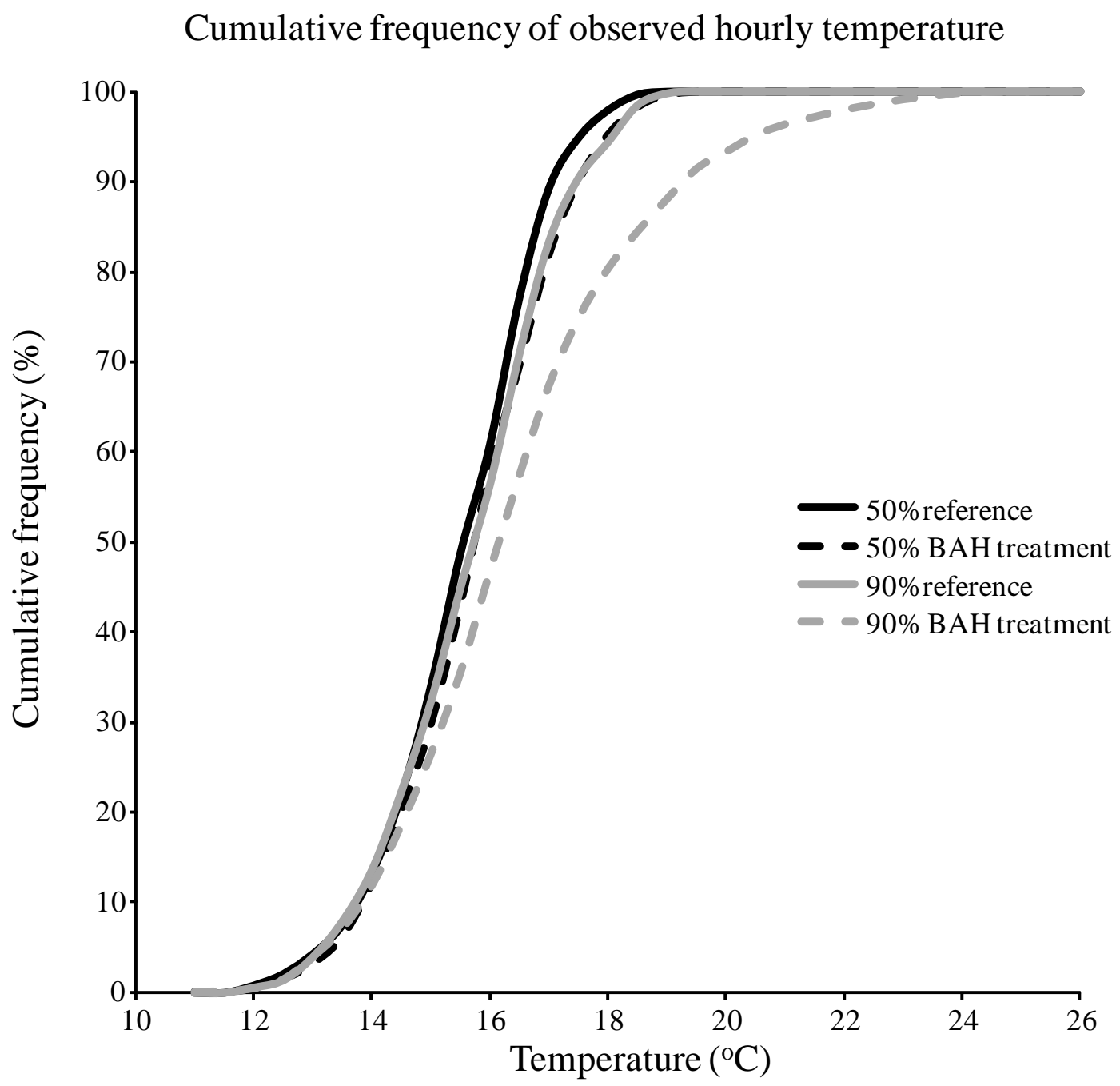

Figure 5. Cumulative frequency of hourly stream temperatures observed during one month in summer, 2009. Eight headwater Appalachian streams were monitor, four with 50\% basal area harvest (BAH) sections and four with 90\% BAH sections. 


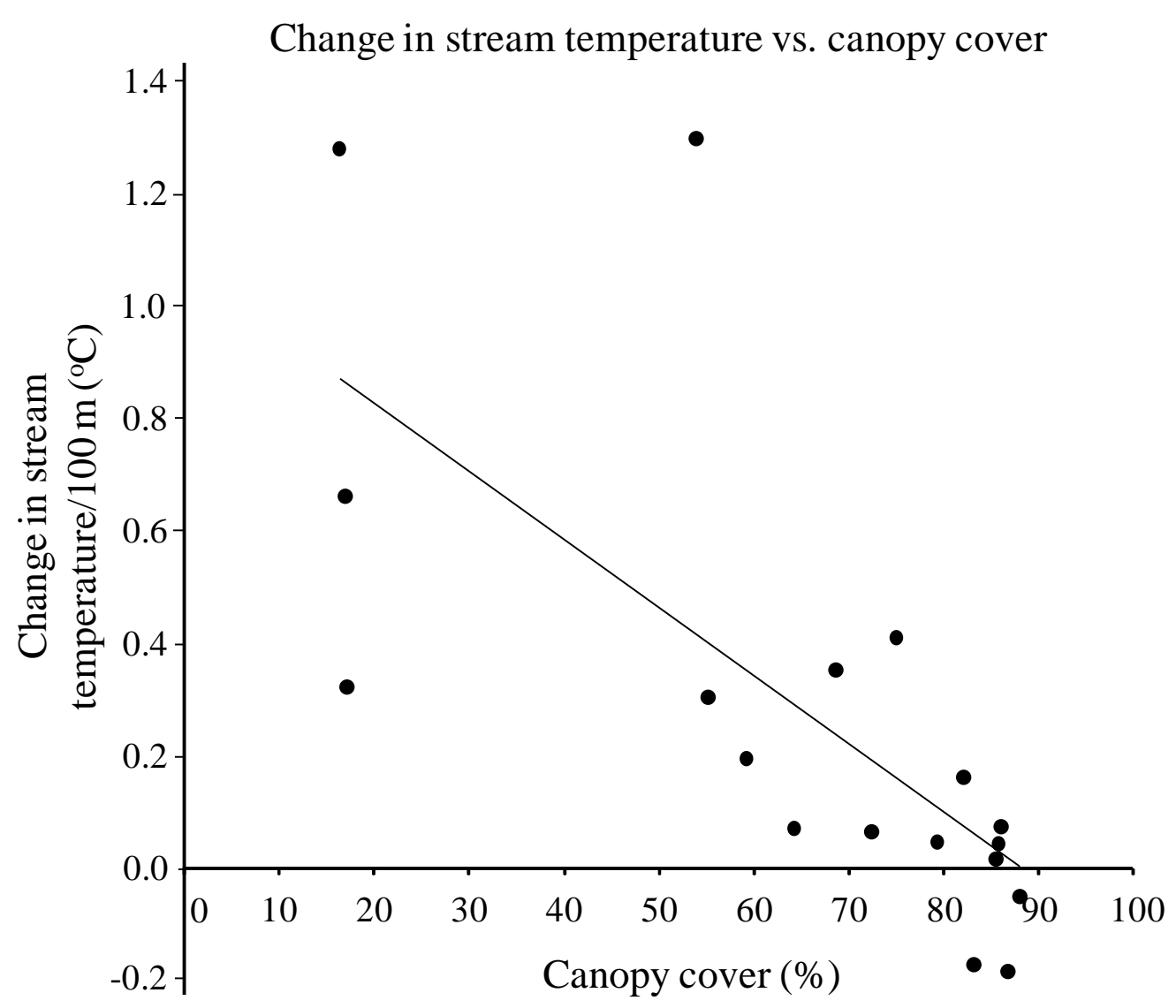

Figure 6. A significant negative relationship was detected between canopy cover and change in stream temperature $\left(\mathrm{p}<0.001, \mathrm{r}^{2}=0.49\right)$. Some points represent unharvested sections downstream of treatment sections where cooling was observed. The regression line is $y=-0.012 x+1.070$. 


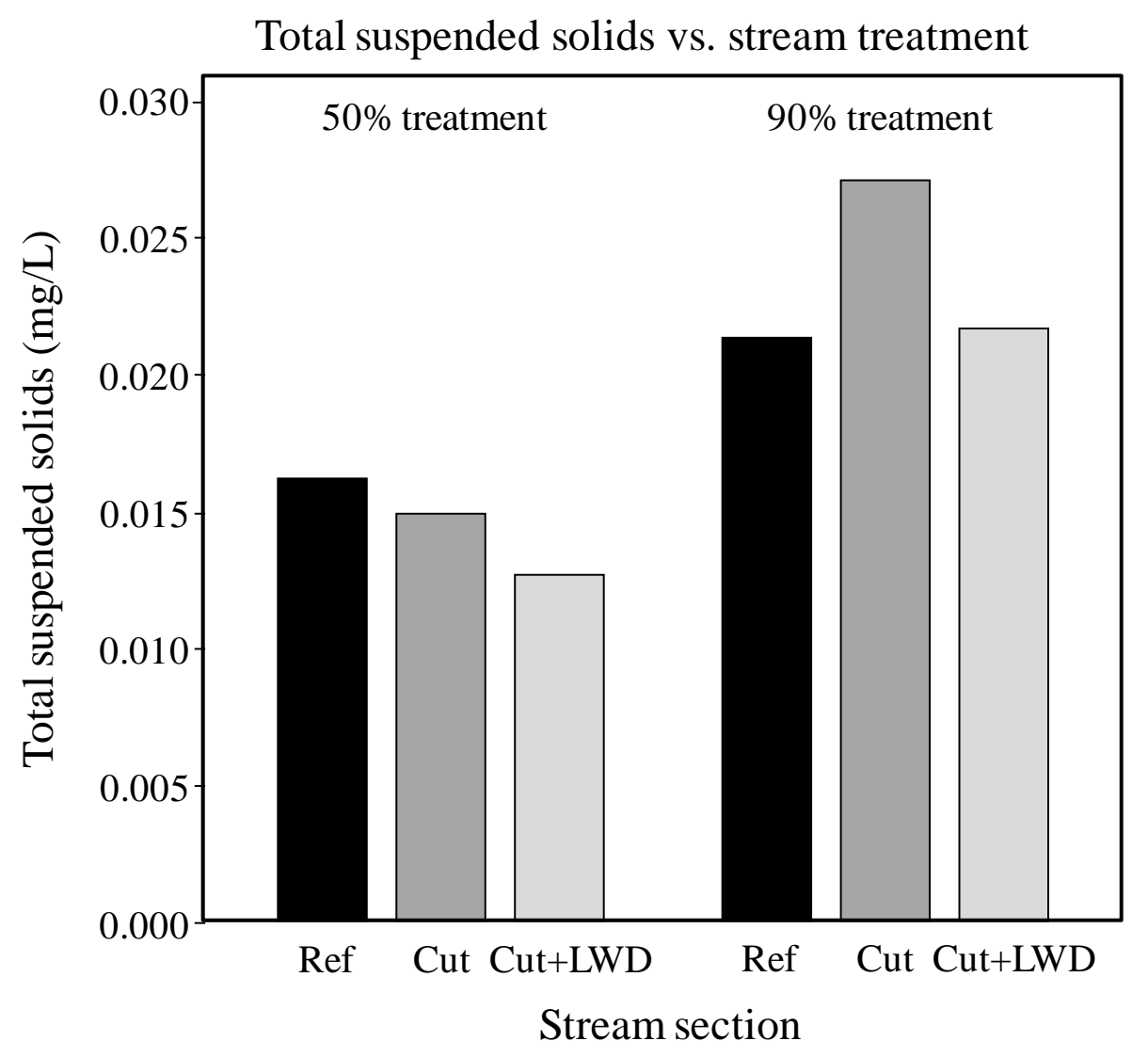

Figure 7. The 50\% and $90 \% \mathrm{BAH}$ and LWD treatments did not significantly affect total suspended solids within the treatment sections of eight headwater streams $(50 \% \mathrm{BAH} \mathrm{p}=0.835$, $90 \%$ BAH $\mathrm{p}=0.258)$. 


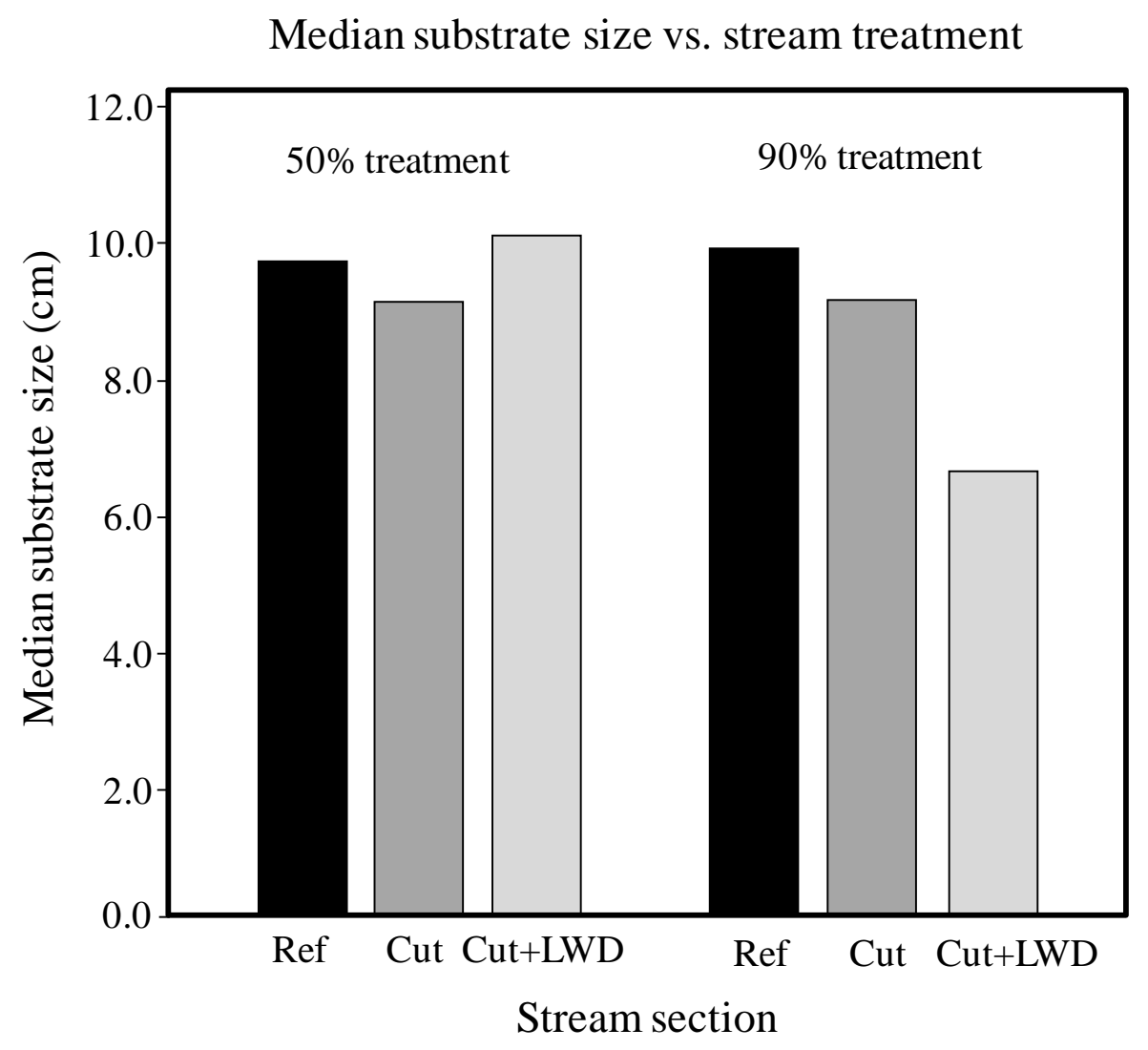

Figure 8 . The $50 \%$ and $90 \%$ BAH treatments and LWD additions did not significantly affect substrate size within the treatment sections of eight headwater streams $(50 \% \mathrm{BAH} p=0.413,90 \%$ BAH $\mathrm{p}=0.184)$. 


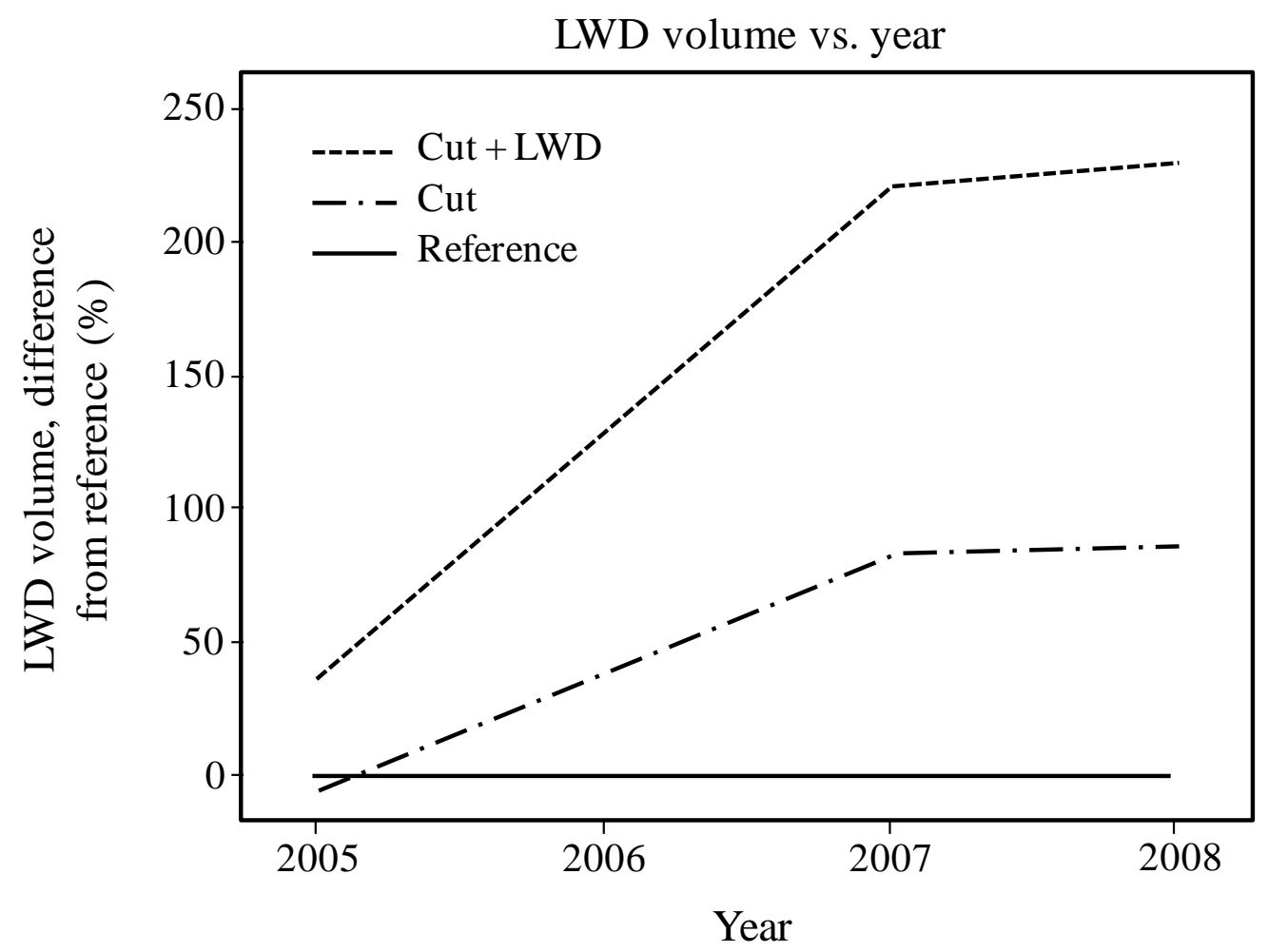

Figure 9. Pre- and post-treatment LWD amounts within the experimental sections of eight headwater streams. In-stream LWD volume was significantly greater in the LWD addition treatments than the corresponding reference sections in 2007 and 2008 ( $p=0.025$ for both). LWD volume appeared to increase in the harvested sections (no LWD addition), although not significantly $(2007 \mathrm{p}=0.093,2008 \mathrm{p}=0.401)$. The treatments were performed in late-2005 and early-2006. LWD was not surveyed in 2006. To facilitate interpretation and remove the effects of annual differences in surveyors performing a subjective survey, this figure presents mean LWD volumes as they relate to their corresponding references. Statistical tests were performed with raw data. 


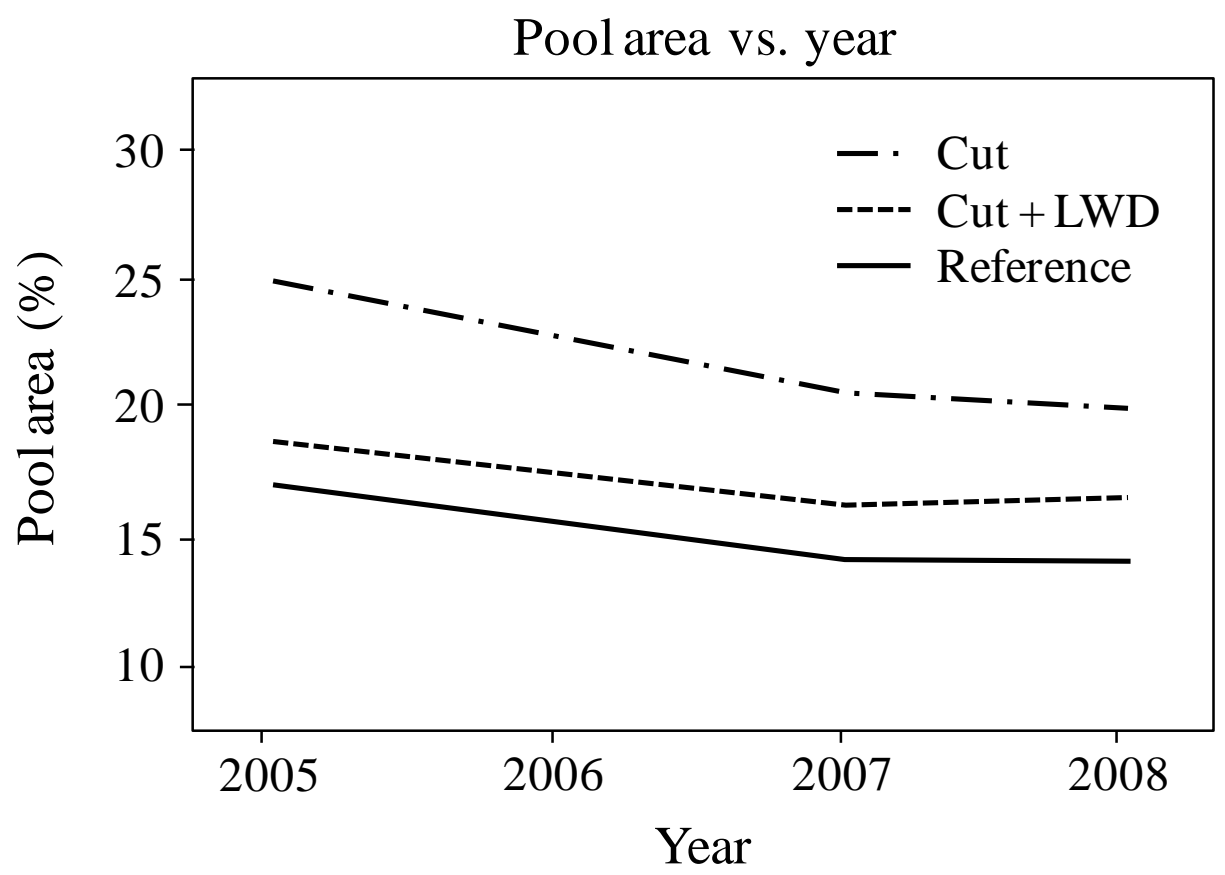

Figure 10. Pre- and post-treatment pool area within experimental sections of eight headwater streams. There was no significant effect of treatment on pool area $(\mathrm{p}=0.942)$. Treatments occurred in late-2005 and early-2006. No habitat surveys were performed in 2006. 


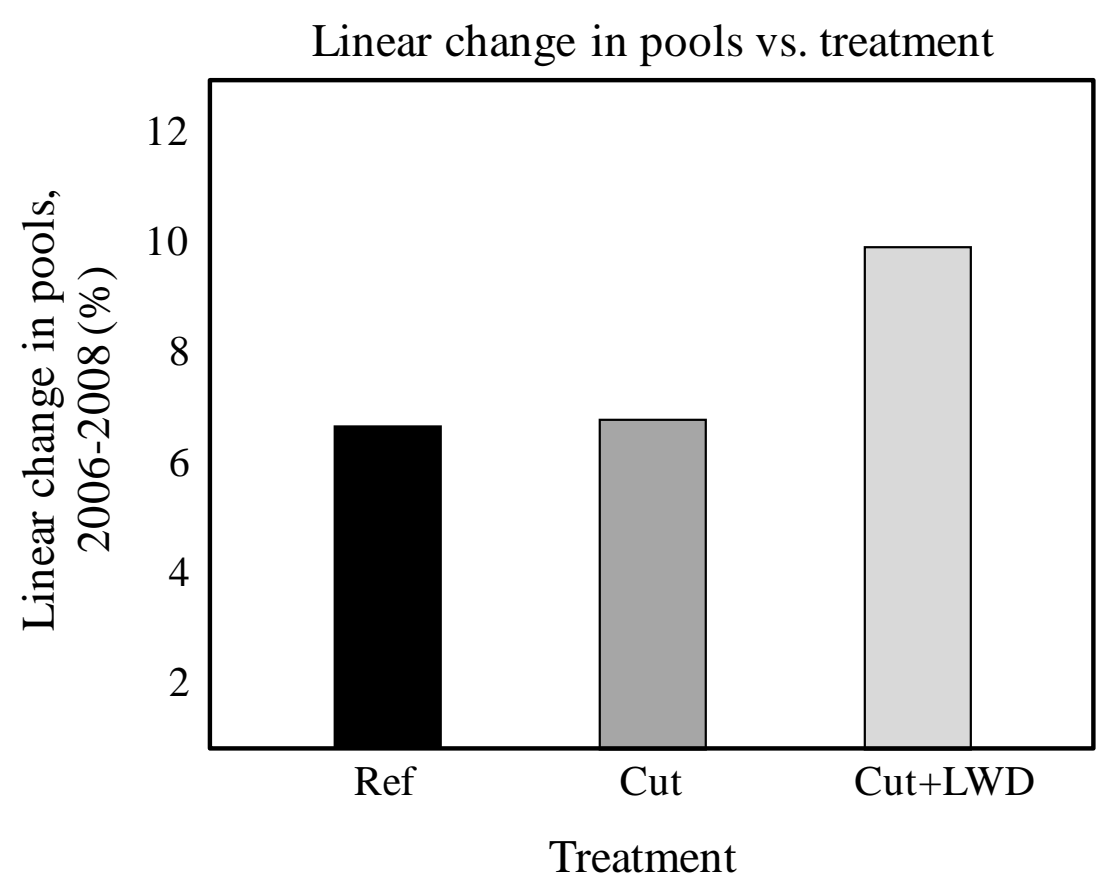

Figure 11. A comparison of linear change from pre-treatment (2006) to post-treatment (2008) found significant differences between treatment sections in eight Appalachian headwater streams $(\mathrm{p}=0.021)$. Post hoc tests determined that the instability in the LWD addition sections was higher than in both the reference and harvest-only sections ( $\mathrm{p}=0.016$ and $\mathrm{p}=0.017$, respectively). Pools were created and destroyed at a higher rate in the LWD addition sections. 


\section{References}

Bilby, R. E. 1981. Role of organic debris dams in regulating the export of dissolved and particulate matter from a forested watershed. Ecology 62:1234-1243.

Bilby, R. E. 1984. Removal of woody debris may affect stream channel stability. Journal of Forestry 82(10):609-613.

Bilby, R. E., and G. E. Likens. 1980. Importance of organic debris dams in the structure and function of stream ecosystems. Ecology 61:1107-1113.

Chih, T. Y. 1971. Potential energy and stream morphology. Water Resources Research 7(2):311322.

Davies, P. E., and M. Nelson. 1994. Relationships between riparian buffer widths and the effects of logging on stream habitat, invertebrate community composition and fish abundance. Australian Journal of Marine and Freshwater Research 45(7):1289-1305.

De Groot, J. D., S. G. Hinch, and J. S. Richardson. 2007. Effects of logging second-growth forests on headwater populations of coastal cutthroat trout: a 6-year, multistream, beforeand-after field experiment. Transactions of the American Fisheries Society 136:211-226.

Dolloff, C. A., H. E. Jennings, and M. D. Owen. 1997. A comparison of basinwide and representative reach habitat survey techniques in three southern Appalachian watersheds. North American Journal of Fisheries Management 17(2):339-347.

Flebbe, P. A., and C. A. Dolloff. 1995. Trout use of woody debris and habitat in Appalachian wilderness streams of North Carolina. North American Journal of Fisheries Management 15(3):579-590.

Gurnell, A. M., K. J. Gregory, and G. E. Petts. 1995. The role of coarse woody debris in forest aquatic habitats: implications for management. Aquatic Conservation: Marine and Freshwater Ecosystems 5:143-166.

Haggerty, S. M., D. P. Batzer, and C. R. Jackson. 2004. Macroinvertebrate response to logging in coastal headwater streams of Washington, U.S.A. Canadian Journal of Fisheries and Aquatic Sciences 61(4):529-537.

Haines, T. A., and J. P. Baker. 1986. Evidence of fish population responses to acidification in the Eastern United States. Water, Air, \& Soil Pollution 31(3):605-629.

Hartman, K. J., and M. K. Cox. 2008. Refinement and testing of a brook trout bioenergetics model. Transactions of the American Fisheries Society 137(1):357-363.

Hartman, K. J., and J. P. Hakala. 2006. Relationships between fine sediment and brook trout recruitment in forested headwater streams. Journal of Freshwater Ecology 21(2):215-230.

Hernanadez, O., R. W. Merritt, and M. S. Wipfli. 2005. Benthic invertebrate community structure is influenced by forest succession after clearcut logging in southeastern Alaska. Hydrobiologia 533:45-59.

Hetrick, N. J., M. A. Brusven, W. R. Meehan, and T. C. Bjornn. 1998. Changes in solar input, water temperature, periphyton accumulation, and allochthonous input and storage after canopy removal along two small salmon streams in southeast Alaska. Transactions of the American Fisheries Society 127(6):859-875.

Hilderbrand, R. H., A. D. Lemly, C. A. Dolloff, and K. L. Harpster. 1997. Effects of large woody debris placement on stream channels and benthic macroinvertebrates. Canadian Journal of Fisheries and Aquatic Sciences 54(4):931-939.

Hynes, H. B. N. 1970. The Ecology of Running Waters. University of Toronto, Toronto. 
Jones, E. B. D., III, G. S. Helfman, J. O. Harper, and P. V. Bolstad. 1999. Effects of riparian forest removal on fish assemblages in southern Appalachian streams. Conservation Biology 13(6): 1454-1465.

Kaller, M., and K. Hartman. 2004. Evidence of a threshold level of fine sediment accumulation for altering benthic macroinvertebrate communities. Hydrobiologia 518:1-3.

Keller, J. R., and F. J. Swanson. 1979. Effects of large organic material on channel form and fluvial processes. Earth Surface Processes 4:361-380.

Kiffney, P. M., J. S. Richardson, and J. P. Bull. 2003. Responses of periphyton and insects to experimental manipulation of riparian buffer width along forest streams. Journal of Applied Ecology 40(6):1060-1076.

Kishi, D., M. Murakami, S. Nakano, and Y. Taniguchi. 2004. Effects of forestry on the thermal habitat of Dolly Varden (Salvelinus malma). Ecological Research 19:283-290.

Kochenderfer, J. N., P. J. Edwards, and F. Wood. 1997. Hydrologic impacts of logging an Appalachian watershed using West Virginia's best management practices. Northern Journal of Applied Forestry 14:207-218.

Kreutzweiser, D. P., and S. S. Capell. 2001. Fine sediment deposition in streams after selective forest harvesting without riparian buffers. Canadian journal of forest research 31(12):2134-2142.

Kreutzweiser, D. P., S. S. Capell, and K. P. Good. 2005. Macroinvertebrate community responses to selection logging in riparian and upland areas of headwater catchments in a northern hardwood forest. Journal of the North American Benthological Society 24:208222.

Larson, G. L., and S. E. Moore. 1985. Encroachment of exotic rainbow trout into stream populations of native brook trout in the southern Appalachian Mountains. Transactions of the American Fisheries Society 114(2):195-203.

Lee, P., C. Smyth, and S. Boutin. 2004. Quantitative review of riparian buffer width guidelines from Canada to the United States. Journal of Environmental Management 70:165-180.

Leopold, L. B., G. M. Wolman, and J. P. Miller. 1964. Fluvial Processes in Geomorphology. W.H. Freeman and Company, San Francisco.

Lowrance, R., J. K. Sharpe, and J. M. Sheridan. 1986. Long-term sediment deposition in the riparian zone of a coastal plain watershed. Journal of Soil and Water Conservation 41(4):266-271.

McCormick, J. H., K. E. F. Hokanson, and B. R. Jones. 1972. Effects of temperature on growth and survival of young brook trout, Salvelinus fontinalis. Journal of the Fisheries Research Board of Canada 29(8):1107-1112.

Meehan, W. R., and T. C. Bjornn. 1991. Salmonid distributions and life histories. Pages 47-82 in W. R. Meehan, editor. Influences of forest and rangeland management. American Fisheries Society, Bethesda, MD.

Moore, R., D. L. Spittlehouse, and A. Story. 2005. Riparian microclimate and stream temperature response to forest harvesting: a review. Journal of the American Water Resources Association 41(4):813-834.

Naiman, R. J., and H. Decamps. 1997. The ecology of interfaces: riparian zones. Annual Review of Ecology and Systematics 28:621-658.

Naiman, R. J., H. Decamps, J. Pastor, and C. A. Johnston. 1988. The potential importance of boundaries to fluvial ecosystems. Journal of the North American Benthological Society 7(4):289-306. 
Pearce, R. A., and coauthors. 1998. Sediment filtration in a montane riparian zone under simulated rainfall. Journal of Range Management 51(3):309-314.

Peterson, R. H., A. M. Sutterlin, and J. L. Metcalfe. 1979. Temperature preference of several species of Salmo and Salvelinus and some of their hybrids. Journal of the Fisheries Research Board of Canada 36:1137-1140.

Petty, J. T., P. J. Lamothe, and P. M. Mazik. 2005. Spatial and seasonal dynamics of brook trout populations inhabiting a central Appalachian watershed. Transactions of the American Fisheries Society 134(3):572-587.

Power, G. 1980. The brook charr, Salvelinus Fontinalis. Pages 141-203 in E. K. Balon, editor. Charrs: salmonid fishes of the genus Salvelinus. Dr. W. Junk, The Hague, Netherlands.

Richmond, A. D., and K. D. Fausch. 1995. Characteristics and function of large woody debris in subalpine Rocky Mountain streams in northern Colorado. Canadian Journal of Fisheries and Aquatic Sciences 52(8):1789-1802.

Rosenfeld, J., M. Porter, and E. Parkinson. 2000. Habitat factors affecting the abundace and distribution of juvenile cutthroat trout (Oncorhynchus clarki) and coho salmon (Oncorhynchus kisutch). Canadian Journal of Fisheries and Aquatic Sciences 57:7667740 .

Silsbee, D. G., and G. L. Larson. 1983. A comparison of streams in logged and unlogged areas of Great Smoky Mountains National Park. Hydrobiologia 102(2):99-111.

Sugimoto, S., F. Nakamura, and A. Ito. 1997. Heat budget and statistical analysis of the relationship between stream temperature and riparian forest in the Toikanbetsu River basin, northern Japan. Journal of Forest Research 2(2):103-107.

Swank, W. T., J. M. Vose, and K. J. Elliott. 2001. Long-term hydrologic and water quality responses following commercial clearcutting of mixed hardwoods on a southern Appalachian catchment. Forest Ecology and Management 143:1-3.

Sweeney, B. W., R. L. Vannote, and P. J. Dodds. 1986. The relative importance of temperature and diet to larval development and adult size of the winter stonefly, Soyedina carolinensis (Plectoptera: Nemouridae). Freshwater Biology 16:39-48.

Sweka, J. A., and K. Hartman. 2006. Effects of large woody debris addition on stream habitat and brook trout populations in Appalachian streams. Hydrobiologia 559:363-378.

Sweka, J. A., and K. J. Hartman. 2001a. Effects of turbidity on prey consumption and growth in brook trout and implications for bioenergetics modeling. Canadian Journal of Fisheries and Aquatic Sciences 58(2):386-393.

Sweka, J. A., and K. J. Hartman. 2001b. Fall and winter brook trout prey selection and daily ration. Source Proceedings of the Annual Conference of the Southeastern Association of Fish and Wildlife Agencies 55:8-22.

Team, R. D. C. 2009. R: A language and environment for statistical computing, reference index version 2.9.1. R Foundation for Statistical Computing, Vienna.

Trotter, E. H. 1990. Woody debris, forest-stream, succession, and catchment geomorphology. Journal of the North American Benthological Society 9(2):141-156.

Utz, R. M., and K. J. Hartman. 2006. Temporal and spatial variation in the energy intake of a brook trout (Salvelinus fontinalis) population in an Appalachian watershed. Canadian Journal of Fisheries and Aquatic Sciences 63(12):2675-2686.

Van Sambeek, J. W., J. O. Dawson, F. J. Ponder, E. F. Loewenstein, and J. S. Fralish, eds. 2003. Proceedings, 13th annual Central Hardwood Forest conference; 2002 April 1-3; Urbana, Illinois. 13th Central Hardwood Forest conference. 
West Virginia Division of Foresty, 2005. West Virginia silvicultural best management practices for controlling soil erosion and sedimentation from logging operations. WVDOF-TR-053.

Wood, P. J., and P. D. Armitage. 1997. Biological effects of fine sediment in the lotic environment. Environmental Management 21(2):203-217. 
Chapter 3: The effects of riparian forest harvest intensity on stream periphyton biomass

\title{
Jered M. Studinski
}

\begin{abstract}
In forested headwater streams, riparian tree harvesting and canopy thinning is expected to result in increased periphyton biomass. An increase in primary productivity can lead to shifts in invertebrate and fish communities. However, the degree of canopy reduction necessary to observe significant changes in periphyton biomass is unclear. This project investigated the effects of riparian tree harvest at $0 \%, 50 \%$, and $90 \%$ basal area harvest (BAH) on periphyton biomass in 8 headwater streams in West Virginia. Additionally, the effects of alkalinity and temperature on periphyton biomass were investigated.

The riparian treatments created a gradient of canopy coverage although there was little overlap between treatments. Canopy coverage means were $84 \%, 73 \%$, and $40 \%$ for reference, 50\% BAH, and 90\% BAH sections, respectively. Canopy thinning significantly increased periphyton biomass, although the relationship was fairly weak $\left(\mathrm{R}^{2}=0.283\right)$. At the stream level, canopy reductions as low as $6.4 \%$ resulted in increased periphyton biomass. Temperature increased in the harvested sections, but neither temperature nor alkalinity affected periphyton biomass over the short ranges of values that were present. To prevent possible trophic disruption, changes in canopy cover should be considered when attempting to limit the impacts of riparian tree harvest.
\end{abstract}




\section{Introduction}

Forested headwater streams are heterotrophic systems that rely on the surrounding forest for detrital resources (Vannote et al. 1980). Stream fauna are well-adapted to utilize the resources provided by the riparian forest (Wallace and Webster 1995). Riparian disturbance such as timber harvest has the potential to modify headwater stream food webs via increased light, increased temperature, and the removal of the detritus source. These variables, along with nutrient availability, regulate primary production (Meehan and Bjornn 1991; Shortreed and Stockner 1983; Stephens and Smith 2003; Wallace et al. 1997).

Increased in-stream primary production leads to changes in fish and invertebrate assemblages, favoring taxa that are adapted to utilize autochthonous materials (Gurtz and Wallace 1984; Stone and Wallace 1998). These changes may result in a loss of a diversity at the stream level as disturbed upstream sections become redundant to downstream sections, although disturbance has been linked to increases and decreases in diversity at the patch level (Brown et al. 1997; Haggerty et al. 2004; Hernanadez et al. 2005; Jones et al. 1999; Quinn et al. 2004; Silsbee and Larson 1983). The effects of this trophic disturbance on animal biomass are similarly variable (Davies and Nelson 1994; Hernanadez et al. 2005), although it may follow patterns of patch-level increase.

Due to the demand for forest products and the prevalence of headwater streams, logging near headwater streams in inevitable. Riparian logging increases primary production via canopy thinning (Kiffney et al. 2003; Quinn et al. 2004; Quinn et al. 1997). Best management practices (BMP's) have been developed to minimize the impacts of riparian timber harvest on streams.

Within the U.S.A., actual guidelines and requirements vary by region and state (Lee et al. 2004). The main component of these guidelines is the establishment of a streamside management zone 
(SMZ). The SMZ is a riparian buffer within which disturbance is limited. The West Virginia Division of Forestry's (WVDF) BMP's require a SMZ that is at least $30 \mathrm{~m}$ wide for perennial and intermittent streams and is road-free (West Virginia Division of Forestry 2005). Trees can be harvested from the SMZ (there is no harvest limit) but the operation of large equipment in this area is to be avoided. These regulations are directed at minimizing erosion and sedimentation and do not appear to consider the impacts of increased light and temperature.

Stream biota are structured by available energy resources, making this basic, bottom-up effect important to understand. Most previous studies have focused on either the impacts of clearcutting the riparian zone (Boothroyd et al. 2004; Hetrick et al. 1998; Shortreed and Stockner 1983) or the effects of different riparian buffer widths (Davies and Nelson 1994; Kiffney et al. 2003). This study quantified the periphyton biomass response to riparian logging within a $30-\mathrm{m}$ buffer at three harvest intensities: $0 \%, 50 \%$, and $90 \%$ basal area harvest (BAH).

\section{Methods}

\section{Study area}

The study area is described in chapter 2 . To avoid the confounding effects of the LWD treatments, no periphyton samples were taken from those sections.

\section{Periphyton biomass}

In mid-June 2008, 20 numbered, unglazed red clay tiles $\left(15.24 \mathrm{~cm} \mathrm{x} 15.24 \mathrm{~cm}, 0.023 \mathrm{~m}^{2}\right)$ were placed in both the treatment and reference sections of 8 streams (Quinn et al. 2004). Tiles were placed in the thalweg of narrow, deep riffles, with a corner pointing upstream. The previous year's attempts revealed this would reduce data loss due to fluctuating water levels (in shallow 
areas), coverage in silt and sand (in low velocity areas) and overturned tiles (from the leading edge being perpendicular to stream flow). Tiles were collected in late-July, after 40 days of immersion ensured stable periphyton colonies (Shortreed and Stockner 1983). The surfaces of the tiles were lightly rinsed with distilled water to remove loose material. Periphyton was then removed from the tiles by scrubbing with a stiff nylon brush. Distilled water was used to rinse the tiles and brush. The periphyton from three to five tiles was combined into a sample jar and the tiles' identification numbers were recorded. Within 12 hours, the periphyton was filtered through $0.7 \mu \mathrm{m}$ pore pre-burned and pre-weighed glass fiber filters using a hand pump. The filters were dried to a constant weight and weighed to the nearest $0.0001 \mathrm{~g}$. The filters were then burned in a furnace at $500^{\circ} \mathrm{C}$ and weighed again. Burned weight was subtracted from dried weight to yield ash free dry mass (AFDM).

Canopy coverage, stream temperature, and alkalinity data were collected to relate to periphyton biomass. At each tile, canopy was assessed using a digital camera and photograph analysis, and the average canopy coverage was calculated for each composite periphyton sample (see chapter 2 for details). $\mathrm{HOBO}^{\circledR}$ Water Temp Pro data loggers collected temperature information (see chapter 2 for details). All water temperature data was reduced to the stream section's mean temperature during the periphyton sampling period. For four steams, data logger deployment was concurrent with periphyton colonization. For the other four streams, temperature data was collected for a 30-day period, starting 7 days after the tiles were removed. Mean daily air temperature between the two water temperature sampling periods differed only by $0.4^{\circ} \mathrm{C}$, permitting the use of the later water temperature data set. For each stream, alkalinity was determined via titration at the West Virginia Department of Natural Resources lab in Elkins. 
Two water samples were analyzed from each stream and the results combined into a single stream-wide alkalinity value.

Program R (R Development Core Team 2009) was used for all data analyses. A Kruskal -Wallis test was used to evaluate the effects of the treatments on canopy coverage. Multiple linear regression was used to evaluate the addition of stream temperature and alkalinity to the periphyton/canopy relationship. To increase the sample size from four to eight, a paired t-test was used to compare periphyton AFDM in the treatment sections to their corresponding reference sections, regardless of logging intensity.

\section{Results}

The reference and treatments of 50\% and 90\% BAH produced 3 distinct groups of canopy coverage (see chapter 2 for details). Most tiles in Mulberry Creek (a 50\% BAH stream) were covered with sand during a limestone sand treatment; therefore, the stream was removed from the analyses.

Periphyton AFDM was significantly higher in the treatment sections $(\mathrm{p}=0.007)$. An initial scatterplot of periphyton AFDM versus canopy cover shows considerable variation at lower canopy coverage and no evidence of a non-linear relationship (Figure 1). To avoid pseudoreplication, values within treatment sections were averaged to produce single reference and treatment values for each stream (Table 1, Figure 2 [periphyton vs. canopy: $R^{2}=0.283, p=$ 0.056]). Multiple linear regression revealed that the periphyton vs. canopy relationship was not improved with the addition of temperature or alkalinity. 


\section{Discussion}

As with other studies, a significant negative relationship between canopy cover and periphyton biomass was observed (Kiffney et al. 2003; Quinn et al. 1997; Stephens and Smith 2003). However, we did not detect any influence of temperature and alkalinity on periphyton biomass. Mean stream temperatures during the periphyton sampling period were $14.5-16.6^{\circ} \mathrm{C}$. It may not be realistic to expect a detectable influence of temperature along such a small gradient. The lack of influence of temperature on periphyton biomass is similar to observations and predictions of other studies with similar temperature gradients (Phinney and McIntire 1965; Shortreed and Stockner 1983). Although alkalinity (or the strongly correlated $\mathrm{pH}$ ) is critical in the regulation of many stream processes, there is little evidence of its direct effects on periphyton biomass, including this study. The assumption that higher alkalinities results in healthier, more-productive streams means those streams could also support more fish and invertebrates. Healthy populations of grazers can reduce the standing crop of periphyton (Gresens 1995; Power et al. 1985; Wallace and Webster 1995), confounding not only the effects of alkalinity but also canopy coverage (Quinn et al. 1997).

The large amount of between-stream variability in the periphyton response indicates other factors may be influencing these systems. Nutrient availability was never assessed. Nitrogen and phosphorus are known to be important limiting factors of primary production in aquatic systems (Murphy and Meehan 1991; Stephens and Smith 2003). The observed periphyton increases indicate that, unlike in some headwater systems, nitrogen and phosphorus are available to fuel a periphyton response (Stockner and Shortreed 1978). Another unmeasured variable was water velocity at the sample site which can affect the impacts of invertebrate grazers (Opsahl et al. 2003). Although within-stream variation was somewhat minimized by 
standardizing the location of tiles to deeper, high-velocity riffles, between-stream variations in water velocity still exist.

The results indicate that in these streams, periphyton is light-limited. When periphyton AFDM was compared between treatments and their references (both 50\% and 90\% BAH treatments tested together), significant differences were observed. Although no statistical tests compared within-stream variation, all streams had trends of increasing periphyton biomass as canopy cover decreased, even with canopy reductions as small as 6.4\% (Table 1, Figure 2).

To prevent possible trophic disruption, changes in canopy cover need to be considered when attempting to reduce the impacts of riparian tree harvest. If the objective of riparian protection is zero measurable impact, then it is doubtful that this could be achieved with any level of riparian logging. However, low levels of canopy thinning may increase stream productivity by increasing primary productivity, especially if negative impacts like increased temperature and reduced allochthonous materials are minimized. 
Table 1. Descriptive statistics from seven Appalachian headwater streams. All values are section averages.

\begin{tabular}{|c|c|c|c|c|c|}
\hline Stream & Section & $\begin{array}{r}\text { Periphyton } \\
\text { AFDM }\left(\mathrm{mg} / \mathrm{m}^{2}\right)\end{array}$ & $\begin{array}{r}\text { Canopy } \\
(\%) \\
\end{array}$ & $\begin{array}{l}\text { Mean daily } \\
\text { temp. }\left({ }^{\circ} \mathrm{C}\right)\end{array}$ & $\begin{array}{r}\text { Alkalinity }(\mathrm{mg} \\
\left.\mathrm{CaCO}_{3} / \mathrm{L}\right) \\
\end{array}$ \\
\hline \multirow{2}{*}{ Birch } & treat $(50 \%)$ & 0.246 & 72.2 & 15.3 & \multirow{2}{*}{21.14} \\
\hline & ref & 0.136 & 88.0 & 14.9 & \\
\hline \multirow{2}{*}{ Kittle } & treat $(50 \%)$ & 0.260 & 61.1 & 16.4 & \multirow{2}{*}{11.90} \\
\hline & ref & 0.141 & 83.3 & 16.2 & \\
\hline \multirow{2}{*}{ N. Br. Panther } & treat $(50 \%)$ & 0.272 & 73.9 & 16.1 & \multirow{2}{*}{33.00} \\
\hline & ref & 0.070 & 80.3 & 15.9 & \\
\hline \multirow{2}{*}{ Mitchell } & treat $(90 \%)$ & 0.197 & 13.8 & 15.8 & \multirow{2}{*}{27.27} \\
\hline & ref & 0.097 & 80.3 & 15.2 & \\
\hline \multirow{2}{*}{ Rocky } & treat $(90 \%)$ & 0.349 & 34.1 & 15.2 & \multirow{2}{*}{4.32} \\
\hline & ref & 0.046 & 82.9 & 14.5 & \\
\hline \multirow{2}{*}{ S. Br. Panther } & treat $(90 \%)$ & 0.099 & 51.2 & 16.3 & \multirow{2}{*}{44.37} \\
\hline & ref & 0.079 & 82.4 & 16.2 & \\
\hline \multirow{2}{*}{ Schoolcraft } & treat $(90 \%)$ & 0.230 & 65.8 & 16.6 & \multirow{2}{*}{28.65} \\
\hline & ref & 0.118 & 85.8 & 15.3 & \\
\hline
\end{tabular}




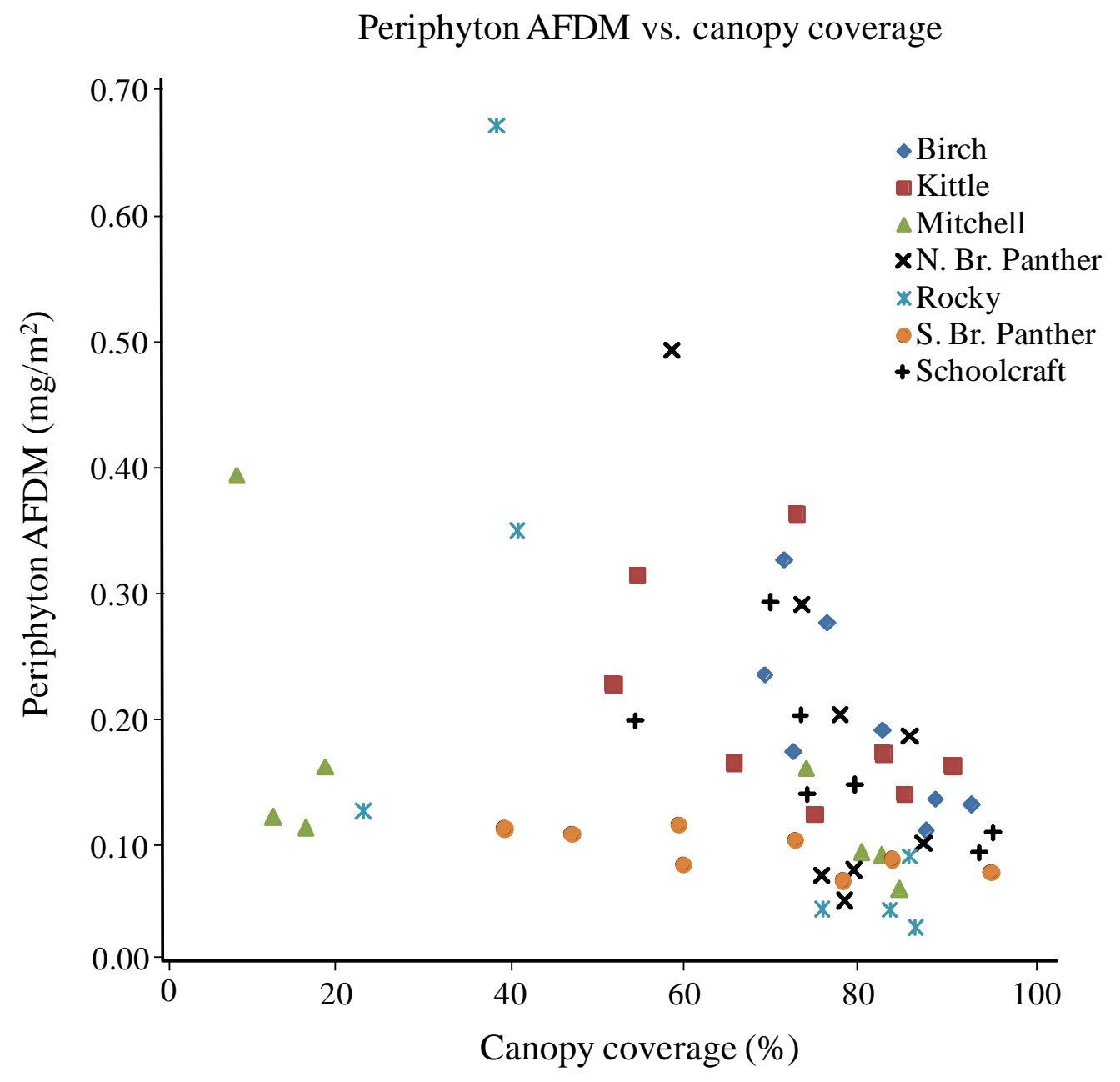

Figure 1. The within- and between-stream response of periphyton biomass to gradients in canopy coverage in seven Appalachian headwater streams. 


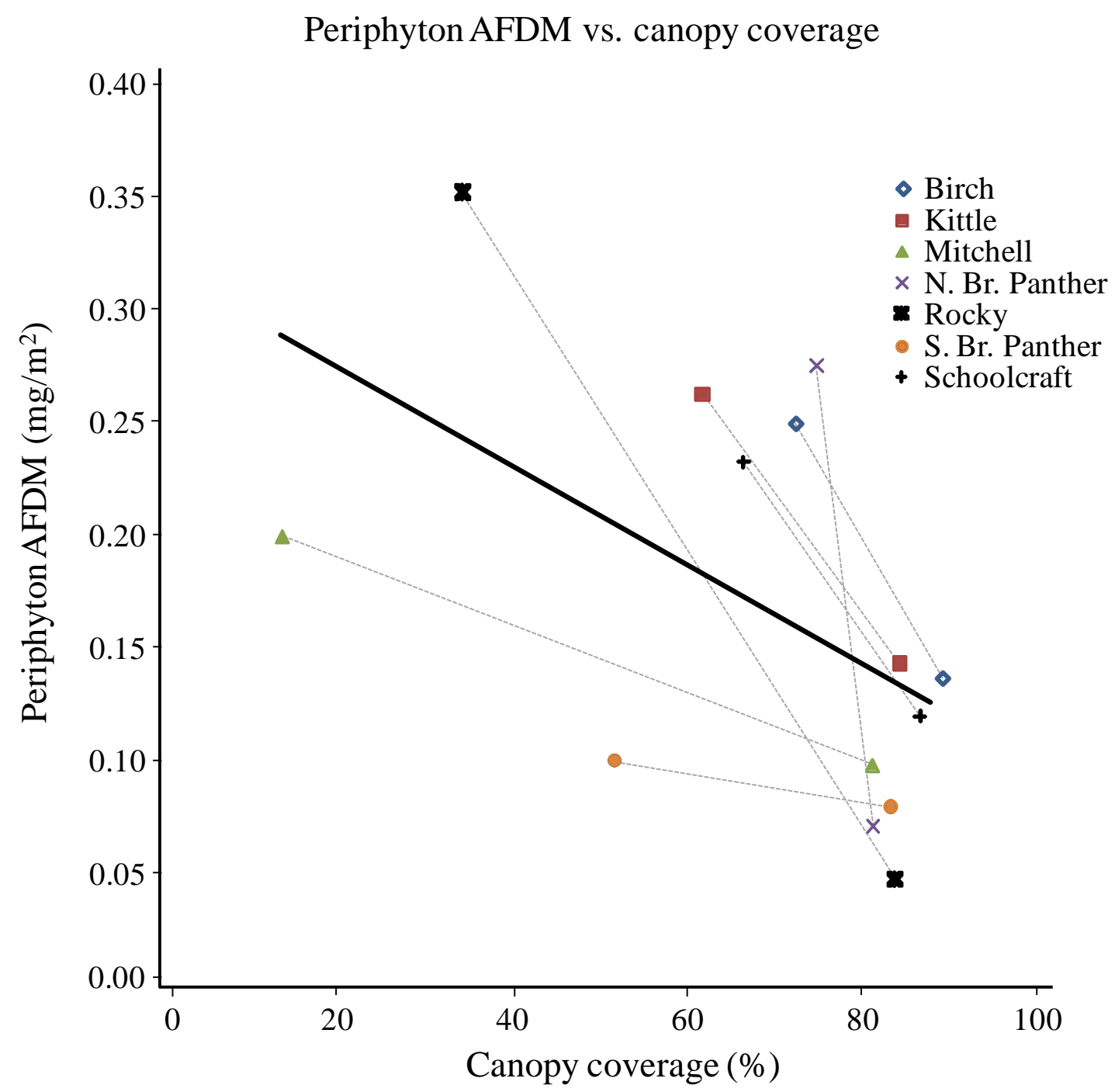

Figure 2. Treatment-reference pairs of mean periphyton biomass along a canopy cover gradient for seven headwater streams. A significant negative relationship was observed, although the predictive value of this model is fairly low $\left(R^{2}=0.283, y=-0.0022 x+0.3169\right)$. Lines between points are provided to depict apparent relationships between canopy coverage and periphyton biomass within streams. 


\section{References}

Boothroyd, I. K., J. M. Quinn, E. R. Langer, K. J. Costley, and G. Steward. 2004. Riparian buffers mitigate effects of pine plantation logging on New Zealand streams. 1. Riparian vegetation structure, stream geomorphology and periphyton. Forest Ecology and Management 194(1-3):199-213.

Brown, A. V., Y. Aguila, K. B. Brown, and W. P. Fowler. 1997. Responses of benthic macroinvertebrates in small intermittent streams to silvicultural practices. Hydrobiologia 347:1-3.

Davies, P. E., and M. Nelson. 1994. Relationships between riparian buffer widths and the effects of logging on stream habitat, invertebrate community composition and fish abundance. Australian Journal of Marine and Freshwater Research 45(7):1289-1305.

Gresens, S. E. 1995. Grazer diversity, competition and the response of the periphyton community. Oikos 73:336-346.

Gurtz, M. E., and J. B. Wallace. 1984. Substrate-mediated response of stream invertebrates to disturbance. Ecology 65(5):1556-1569.

Haggerty, S. M., D. P. Batzer, and C. R. Jackson. 2004. Macroinvertebrate response to logging in coastal headwater streams of Washington, U.S.A. Canadian Journal of Fisheries and Aquatic Sciences 61(4):529-537.

Hernanadez, O., R. W. Merritt, and M. S. Wipfli. 2005. Benthic invertebrate community structure is influenced by forest succession after clearcut logging in southeastern Alaska. Hydrobiologia 533:45-59.

Hetrick, N. J., M. A. Brusven, W. R. Meehan, and T. C. Bjornn. 1998. Changes in solar input, water temperature, periphyton accumulation, and allochthonous input and storage after canopy removal along two small salmon streams in southeast Alaska. Transactions of the American Fisheries Society 127(6):859-875.

Jones, E. B. D., III, G. S. Helfman, J. O. Harper, and P. V. Bolstad. 1999. Effects of riparian forest removal on fish assemblages in southern Appalachian streams. Conservation Biology 13(6): 1454-1465.

Kiffney, P. M., J. S. Richardson, and J. P. Bull. 2003. Responses of periphyton and insects to experimental manipulation of riparian buffer width along forest streams. Journal of Applied Ecology 40(6):1060-1076.

Lee, P., C. Smyth, and S. Boutin. 2004. Quantitative review of riparian buffer width guidelines from Canada to the United States. Journal of Environmental Management 70:165-180.

Meehan, W. R., and T. C. Bjornn. 1991. Salmonid distributions and life histories. Pages 47-82 in W. R. Meehan, editor. Influences of forest and rangeland management. American Fisheries Society, Bethesda, MD.

Murphy, M. L., and W. R. Meehan. 1991. Stream Ecosystems. W. R. Meehan, editor. Influences of forest and rangeland management on salmonid fishes and their habitats. American Fisheries Society, Bethesda, MD.

Opsahl, R. W., T. Wellnitz, and N. L. Poff. 2003. Current velocity and invertebrate grazing regulate stream algae: results of an in situ electrical exclusion. Hydrobiologia 499:135145.

Phinney, H. K., and C. D. McIntire. 1965. Effects of temperature on metabolism of periphyton communities developed in laboratory streams. Limnology and Oceanography 10:341344. 
Power, M. E., W. J. Matthews, and A. J. Stewart. 1985. Grazing minnows, piscivorous bass, and stream algae: dynamics of a strong interaction. Ecology 66(5):1448-1456.

Quinn, J. M., I. K. J. Boothroyd, and B. J. Smith. 2004. Riparian buffers mitigate effects of pine plantation logging on New Zealand streams 2. Invertebrate communities. Forest Ecology and Management 191(1-3):129-146.

Quinn, J. M., A. B. Cooper, M. J. Stroud, and G. P. Burrell. 1997. Shade effects on stream periphyton and invertebrates: An experiment in streamside channels. New Zealand Journal of Marine and Freshwater Research 31(5):665-683.

Shortreed, K. S., and J. G. Stockner. 1983. Periphyton biomass and species composition in a coastal rain forest stream in British Columbia: effects of environmental changes caused by logging. Canadian Journal of Fisheries and Aquatic Sciences 40:1887-1895.

Silsbee, D. G., and G. L. Larson. 1983. A comparison of streams in logged and unlogged areas of Great Smoky Mountains National Park. Hydrobiologia 102(2):99-111.

Stephens, S. H., and C. M. Smith. 2003. Effects of light and nutrients on periphyton community composition in a Hawaiian stream. Journal of Phycology 39(S1).

Stockner, J. G., and K. S. Shortreed. 1978. Enhancement of autotrophic production by nutrient addition in a coastal rainforest stream on Vancouver Island. Journal of the Fisheries Research Board of Canada 35:28-34.

Stone, M. K., and J. B. Wallace. 1998. Long-term recovery of a mountain stream from clear-cut logging: The effects of forest succession on benthic invertebrate community structure. Freshwater Biology 39(1):151-169.

Team, R. D. C. 2009. R: A language and environment for statistical computing, reference index version 2.9.1. R Foundation for Statistical Computing, Vienna.

Vannote, R. L., G. W. Minshall, K. W. Cummins, J. R. Sedell, and C. E. Cushing. 1980. The river continuum concept. Canadian Journal of Fisheries and Aquatic Sciences 37(1):130137.

Wallace, J. B., S. L. Eggert, J. L. Meyer, and J. R. Webster. 1997. Multiple trophic levels of a forest stream linked to terrestrial litter inputs. Science 277(5322):102-104.

Wallace, J. B., and J. R. Webster. 1995. The role of macroinvertebrates in stream ecosystem function. Annual reviews 40:115-139.

West Virginia Division of Foresty, 2005. West Virginia silvicultural best management practices for controlling soil erosion and sedimentation from logging operations. WVDOF-TR-053. 
Chapter 4: The effects of riparian forest logging on terrestrial invertebrate inputs into forested headwater streams

Jered M. Studinski

\begin{abstract}
Terrestrial invertebrates (TI's) are an important food source for stream salmonids, especially in low-productivity headwater streams. Studies have shown that TI's can account for $>50 \%$ of a salmonid's summer diet and the consumption of large TI's is often the difference between feeding above or below maintenance ration. Riparian disturbance is assumed to affect the biomass and composition of TI's entering a stream, but consistent patterns have not emerged. In this study, pan traps were used to quantify the effects of riparian tree harvesting at $0 \%, 50 \%$, and $90 \%$ basal area harvest (BAH) on TI inputs into 8 Appalachian headwater streams in West Virginia during the summers of 2007 and 2008. TI inputs varied by treatment and year. The $90 \%$ BAH treatments had significantly higher TI input biomass due to a shift in composition toward larger taxa. At greater harvest intensities, increases of Acrididae and Tettigoniidae (Orthoptera), woodassociated Coleoptera, Formicidae (ants) and pollinating hymenopterans were observed. No significant changes were attributed to the $50 \% \mathrm{BAH}$ treatments. These results indicate forestry practices can significantly affect TI inputs into Appalachian headwater streams and have the potential to increase fish production.
\end{abstract}




\section{Introduction}

Forested headwater streams have strong interactions with their riparian areas. Recent studies reveal the importance of reciprocal subsidies in determining stream and forest productivity (Nakano and Murakami 2001). Forested headwater stream productivity is heavily dependent on donations of energy from the surrounding forest (Vannote et al. 1980; Wallace et al. 1999). Senesced leaves form the base of a headwater stream food web, with other products such as terrestrial invertebrates (TI's) increasing stream productivity (Kawaguchi et al. 2003; Nakano et al. 1999b). Conversely, forest productivity can be increased by stream products such as fish carcasses and adult aquatic insects (Gende et al. 2002; Nakano and Murakami 2001).

The Allan Paradox, which is based on the observation that fish production in a forested stream was greater than the stream could seemingly support, has been researched for years (Allen 1951; Hynes 1970). Recent data indicate that TI's are an important food source for stream fishes, often comprising over $50 \%$ of their diets during summer months (Allan et al. 2003; Cloe and Garman 1996; Kawaguchi and Nakano 2001; Sweka and Hartman 2008; Webster and Hartman 2005; Wipfli 1997). TI inputs are highest in summer, when fish are under the greatest metabolic demands and streams have low standing crops of aquatic invertebrates (AI's)(Cada et al. 1987; Edwards and Huryn 1995; Kawaguchi and Nakano 2001; Nakano et al. 1999b). The energy supplied by TI's may be critical to salmonids, especially in West Virginia where brook trout typically inhabit low-productivity streams and feed near maintenance ration (Cada et al. 1987; Sweka and Hartman 2001; Utz and Hartman 2006). Allan's Paradox may be explained by the TI subsidy from the riparian area.

The steady demand for forest products and prevalence of headwater streams means logging near streams is inevitable. There has been little research on the effects of riparian 
logging on TI inputs. Canopy thinning and forest composition changes associated with riparian logging are assumed to be factors affecting TI input biomass, but between studies, consistent relationships have not been observed. Edwards and Huryn (1996) found grasslands had higher TI biomass inputs than forests, but Kawaguchi and Nakano (2001) observed the opposite. Batzer et al. (2000) found higher TI inputs in recently harvested forested wetlands, while Allen et al. (2003) found no effects of forest age (young growth versus old growth) or composition on TI input biomass. Assuming that TI input corresponds to TI biomass (Nakano and Murakami 2001), TI inputs are a function of forest productivity. TI biomass following forest disturbance has been shown to either increase (Greenberg and McGrane 1996; Yi and Moldenke 2005) or decrease (Duguay et al. 2000), and may depend on the size of the disturbance (Shure and Phillips 1991).

Best management practices (BMP's) have been developed to minimize the impacts of riparian timber harvest on streams. Within the U.S.A., actual guidelines and requirements vary by region and state (Lee et al. 2004). A major component of these guidelines is the establishment of a streamside management zone (SMZ). The SMZ is a riparian buffer within which disturbance is limited. The West Virginia Division of Forestry's (WVDF) BMP's require a road-free SMZ that is at least $30 \mathrm{~m}$ wide for perennial and intermittent streams (West Virginia Division of Forestry 2005). Trees can be harvested from the SMZ (there is no harvest limit) but the operation of large equipment in this area is to be avoided.

This study quantified the effects of riparian tree harvesting on TI inputs to Appalachian headwater streams. Changes in TI input biomass and composition at 0\%, 50\%, and $90 \%$ basal area harvest $(\mathrm{BAH})$ were quantified. This study produced information regarding the impacts of forestry practices in a region with substantial timber harvesting and little previous research. 


\section{Methods}

Study area

A description of the study area can be found in chapter 2. TI sampling did not occur in the LWD addition sections. Canopy data was collected in the summers of 2007 and 2008. For more information, see chapter 2.

\section{Terrestrial invertebrates}

During July-August of 2007 and 2008, terrestrial invertebrate inputs were sampled with brown plastic pan traps $\left(36.8 \mathrm{~cm} \times 26.7 \mathrm{~cm} \times 10.2 \mathrm{~cm}, 0.11 \mathrm{~m}^{2}\right)($ Kawaguchi and Nakano 2001; Wipfli 1997). In the treatment and reference section of each stream, 40 pans were placed in the stream channel or at the channel's edge (80 pans/stream, 640 total). Pans were placed on spanning logs, exposed rocks, and gravel islands when possible. To prevent pan loss from high flows, each pan was tied to a nearby object. Approximately $10 \mathrm{~cm}$ of stream water was poured into each pan. To keep the pan's environment as natural as possible, no preservatives or attractants were used. Additionally, to avoid overestimating inputs by not allowing chance for escape, no surfactant was used.

Over the course of 30 days, pans were emptied every 3-5 days, depending upon weather conditions and logistical constraints. Within a section, samples were first combined into three composite samples and then statistically combined to represent the stream section. During collection, the date and number of combined pans was recorded to make possible the calculation of abundance and biomass $/ \mathrm{m}^{2} /$ day. Samples were preserved in $80 \%$ ethanol. Most invertebrates were identified to family and their body lengths measured (Borror et al. 1997). Beetles in the subfamily Scolytinae were separated from their family Curculionidae. This was a simple 
determination and aided in the interpretation of the results. Biomass (mg dry weight) was calculated from published length/weight regressions (Sabo et al. 2002; Sage 1982; Sample et al. 1993; Schoener 1980). To roughly assess predation rates by birds, mammals, etc. upon pantrapped invertebrates, 480 pans were observed one day prior to their collection. All trapped invertebrates over $10 \mathrm{~mm}$ were tentatively identified, and had their lengths estimated recorded. During collection, missing invertebrates were noted.

Abundance, biomass, and richness data were averaged by stream section and combined across two years of sampling. ANOVA's with post hoc paired t-tests were used to compare mean terrestrial invertebrate abundance, biomass, and richness between the three harvest intensities. Community analysis was performed using permutational multivariate analysis of variance (PerMANOVA)(Anderson 2001; Anderson 2005; McArdle and Anderson 2001). Communities were compared to their corresponding reference sections in 2007 and 2008 using TI abundance. A PerMANOVA was run with each treatment, where sites were fixed factors nested within years. Data were $\ln (\mathrm{x}+1)$ transformed, and the analyses were based on Bray-Curtis dissimilarities (Bray and Curtis 1957). Permutation of residuals occurred under the reduced model, with 9,999 permutations for all calculated p-values. Bray-Curtis dissimilarity measure is robust to ecological data (McCune and Grace 2002), while permutation under a reduced model gives the best power (Anderson and ter Braak 2003). Since there was no replication at the stream level, samples could not be nested within streams. Stream was included as a covariable. To aid the interpretation of the community analysis, samples were ordinated by taxa abundance using non-metric multidimensional scaling (NMDS) with an overlying canopy vector. Program R (R Development Core Team 2009) was used for all univariate data analyses and NMDS. The program PERMANOVA (Anderson 2005) was used for the PerMANOVA. 


\section{Results}

The riparian treatments affected TI input biomass but not abundance or richness. There were 11,148 TI's from 116 families collected, and overall TI inputs averaged 2.8 invertebrates $/ \mathrm{m}^{2} / \mathrm{day}$. TI abundance and richness did not differ between treatments ( $\mathrm{p}=0.272$ and 0.949 , respectively). Overall TI biomass input was $17.3 \mathrm{mg} / \mathrm{m}^{2} /$ day and was significantly higher in the $90 \% \mathrm{BAH}$ sections compared to reference sections ( $\mathrm{p}=0.018$, Figure 1). A significant increase in TI biomass but not in TI abundance indicates an increase in average body mass of TI's captured in the $90 \%$ BAH sections. Average dry weights for pan-trapped TI's in the reference, 50\%, and $90 \%$ BAH treatments were $6.04 \mathrm{mg}, 6.00 \mathrm{mg}$, and $7.25 \mathrm{mg}$ respectively. Median dry weights in the reference, $50 \%$, and $90 \% \mathrm{BAH}$ treatments were $1.17 \mathrm{mg}, 1.21 \mathrm{mg}$, and $2.10 \mathrm{mg}$ respectively (Figure 2).

The composition of TI inputs was significantly different between years and was affected by the $90 \%$ BAH treatments (Figure 3 [3d solution, stress=13.2]). The TI input composition from the 50\% BAH sections was not significantly different from the corresponding reference sections (four treatment/reference pairs in both 2007 and 2008, nested within year, $\mathrm{p}=0.689$ ). In those four streams, comparisons between 2007 and 2008 (ignoring the treatments within specific stream sections) showed that TI input composition was significantly different between 2007 and 2008 ( $\mathrm{p}=0.001$ ). The TI input composition from the $90 \%$ BAH sections was significantly different from the corresponding reference sections (four treatment/reference pairs in both 2007 and 2008, nested within year, $\mathrm{p}<0.001$ ). Post-hoc tests indicated that the $90 \%$ BAH sections had significantly different TI input composition from corresponding reference sections in both 2007 and 2008 ( $\mathrm{p}=0.029$ and 0.028 , respectively). Additionally, the TI input composition from those four streams was significantly different between 2007 and 2008 ( $(\mathrm{p}<0.001)$. Annual variation, 
which is represented by NMDS axis 1 (Figure 3), appears to be driven by natural fluctuations in the abundance of taxa such as ground beetles (Carabidae), camel crickets (Raphidophoridae), harvestmen (Leiobunidae), and robber flies (Asilidae )(Table 2). The riparian treatments created significant differences in the composition of TI inputs between the $90 \%$ BAH and reference sections in both 2007 and 2008. These differences are effectively represented by NMDS axis 2 (Figure 3), and appear to be driven by the response of taxa such as syncroa bark beetles (Synchroidae), scarabs (Scarabaeidae), ants (Formicidae), and longhorned beetles (Cerambycidae [Table 1]).

Predation rates upon pan-trapped TI's appeared low. From the 480 pans observed a day prior to collection, 87 invertebrates over $10 \mathrm{~mm}$ were observed. The following day, only one invertebrate was missing, yielding a rough loss rate estimation of 1.1\%/day.

\section{Discussion}

While other research has examined the effects of riparian canopy composition or land use on TI inputs, comparisons along a harvest intensity gradient are lacking. The patterns in TI input biomass and abundance observed in this study appear to be similar to some previous studies. However, direct comparisons between studies are difficult due to variation in experimental design, habitat quality, sampling dates, and sampling methods. This study's mean TI input (17.3 $\mathrm{mg} / \mathrm{m}^{2} /$ day, 2.8 individuals $/ \mathrm{m}^{2} /$ day) appears to be comparable to other research within Appalachia (Mason and Macdonald 1982; Romaniszyn et al. 2007), but is lower than research from Japan (Kawaguchi and Nakano 2001; Nakano et al. 1999a) and Alaska (Allan et al. 2003; Wipfli 1997). The increase in TI input biomass in the 90\% BAH treatments is similar to observations of greater TI inputs from grasslands vs. forests (Edwards and Huryn 1996; but see 
Kawaguchi and Nakano 2001). A change in TI input abundance in the 90\% BAH sections was not observed, indicating the increase in input biomass is due to a shift in input composition to larger taxa.

The TI input composition analyses indicated significant differences among treatments and years. Although all sampling occurred post-harvest, samples from 2007 and 2008 differed significantly in composition and were separated along NMDS axis 1 (Table 1, Figure 3). This indicates a high amount of natural yearly variation and illustrates the importance of using concurrently-sampled reference sections with this type of experiment. These results are similar to Yi and Moldenke (2005) who found TI's responded strongest to temporal variation and secondly to canopy thinning.

TI input composition was significantly altered by the $90 \%$ BAH treatments, which is represented along NMDS axis 2 (Table 1, Figure 3). The 50\% BAH treatments had no statistical effect on TI input composition but were intermediate in ordination space (Figure 3). This suggests that future research may reveal changes in TI input composition with $50 \%$ basal removal treatments, especially if those studies employ more than four streams. Vector loadings for NMDS axis 2 indicate positive and negative responses to logging (Table 1). Assuming that TI inputs reflect TI biomass (Nakano and Murakami 2001), these changes are attributable to canopy reduction, changes in plant composition, woody debris increases, and decreases in moisture commonly observed following logging operations (Yi and Moldenke 2005).

Changes in TI input composition along a canopy gradient may be explained by TI life histories. The increases in woody debris that occurred following logging (personal observation) was an important factor. All five coleopteran taxa that increased in the $90 \%$ BAH treatments have wood-associated larvae or adults: Synchroidae (synchroa bark beetles), Cerambycidae 
(long-horned beetles), Buprestidae (metallic wood-boring beetles), Mordellidae (tumbling flower beetles), and Scolytinae (bark beetles) (Borror et al. 1997; Muller et al. 2008). The transition from forested to open conditions resulted in increases in taxa dependent upon herbaceous flowering plants. This includes herbivores and pollinators including Cerambycidae adults, Acrididae (grasshoppers), Tettigonidae (katydids), Halictidae (sweat bees) and Megachilidae (leaf-cutter bees)(Borror et al. 1997; Muller et al. 2008). Increases in generalists, such as Araneae (spiders) and Formicidae (ants), was observed as canopy decreased, which is similar to the results of other researchers (Yi and Moldenke 2005). The decline of Scarabaeidae (scarab beetles) follows a trend observed by Werner and Raffa (2000), and, along with decreases in Staphylinidae (rove beetles) and Mycetophilidae (fungus gnats) may have been a response to decreasing moisture. Most Tenthredinidae (sawflies) and Tortricidae (tortrix moths) rely on tree foliage (Borror et al. 1997), and declined as canopy cover decreased.

In low-productivity streams, riparian donations of TI's are especially important to fish. Riparian conditions (and the corresponding TI inputs) have the potential to affect the spatial distribution of fish (Kawaguchi and Nakano 2001; Kawaguchi et al. 2003). Salmonids show a preference for larger prey items (Allan 1981; Nakano et al. 1999a) which when consumed, can be the difference between feeding below and above maintenance ration (Utz 2005). Since salmonids in headwater streams are usually feeding below maximum consumption, these occasional items are energetically important (Allan 1981; Cada et al. 1987; Utz 2005). Having performed research in some of the same streams as this study, Utz (2005) found that brook trout depended heavily upon terrestrial invertebrates for growth during productive periods and survival during stressful periods. 
The $90 \%$ BAH treatments appear to change the composition and increase the biomass of TI's available to stream salmonids. Although more TI biomass is entering the stream in the $90 \%$ BAH sections, other deleterious effects of riparian logging must be considered. Increases in stream temperature could nullify any energetic gains from increased TI inputs, while increases in sedimentation and loss of allochthonous detritus could reduce the standing crop of aquatic invertebrates. Barring these negative effects, riparian logging could significantly alter TI input composition and biomass and could temporarily increase local fish productivity. 
Table 1. Correlations of taxa abundances along NMDS axis 1 (year effect, 2007-2008) and axis

2 (treatment effect, high canopy coverage to low canopy coverage) for sample sites ordinated by

TI inputs in eight Appalachian headwater streams. Positive correlations along NMDS axis 2

indicate a positive response to riparian canopy thinning. Only correlations over 0.65 are listed.

Correlations are ordered by decreasing percent biomass.

\begin{tabular}{llrrr}
\hline \multicolumn{5}{c}{ NMDS axis 1 } \\
\hline \multicolumn{1}{c}{ Order } & \multicolumn{1}{c}{ Family } & Correlation & $\begin{array}{r}\text { Biomass } \\
(\%)\end{array}$ & $\begin{array}{r}\text { Abundance } \\
\end{array}$ \\
& & -0.91 & 14.90 & 1.84 \\
\hline Coleoptera & Carabidae & -0.97 & 6.98 & 1.10 \\
Orthoptera & Raphidophoridae & -0.90 & 5.66 & 4.78 \\
Opiliones & Leiobunidae & 0.69 & 5.17 & 2.05 \\
Diptera & Asilidae & -1.00 & 3.78 & 3.11 \\
Lepidoptera & Notodontidae & 0.97 & 3.60 & 1.23 \\
Coleoptera & Elateridae & 0.69 & 3.37 & 0.35 \\
Coleoptera & Cerambycidae & 0.91 & 1.98 & 0.78 \\
Hymenoptera & Ichneumonidae & 0.82 & 1.70 & 0.32 \\
Hymenoptera & Apidae & 0.78 & 1.51 & 0.51 \\
Coleoptera & Erotylidae & 0.95 & 1.25 & 0.38 \\
Coleoptera & Lycidae & 0.80 & 0.97 & 0.17 \\
Coleoptera & Pyrochroidae & 0.92 & 0.88 & 0.13 \\
Coleoptera & Melandryidae & -0.75 & 0.80 & 0.82 \\
Lepidoptera & Geometridae & 0.89 & 0.62 & 0.24 \\
Coleoptera & Chrysomelidae & -1.00 & 0.51 & 0.48 \\
Lepidoptera & Arctiidae & 0.71 & 0.41 & 0.21 \\
Coleoptera & Lampyridae & 0.74 & 0.41 & 4.67 \\
Psocoptera & Psocidae & -0.81 & 0.36 & 0.61 \\
Diptera & Muscidae & 0.97 & 0.29 & 0.40 \\
Hemiptera & Pentatomidae & -0.98 & 0.29 & 0.42 \\
Hymenoptera & Braconidae & -0.79 & 0.29 & 0.41 \\
Hemiptera & Reduviidae & 0.71 & 0.24 & 1.13 \\
Coleoptera & Curculionidae & 0.99 & 0.16 & 0.21 \\
Coleoptera & Coccinellidae & & & \\
\hline
\end{tabular}

\begin{tabular}{llrrr}
\hline \multicolumn{4}{c}{ NMDS axis 2} \\
\multicolumn{1}{c}{ Order } & \multicolumn{1}{c}{ Family } & Correlation & $\begin{array}{r}\text { Biomass } \\
(\%)\end{array}$ & Abundance \\
& & & $(\%)$ \\
\hline Coleoptera & Synchroidae & 0.78 & 7.21 & 1.74 \\
Coleoptera & Scarabaeidae & -0.90 & 5.26 & 1.18 \\
Hymenoptera & Formicidae & 0.70 & 5.23 & 6.42 \\
Coleoptera & Cerambycidae & 0.67 & 3.37 & 0.35 \\
Coleoptera & Staphylinidae & -1.00 & 3.21 & 1.47 \\
Araneae & Amaurobiidae & 0.88 & 2.44 & 0.68 \\
Coleoptera & Buprestidae & 0.75 & 1.89 & 0.47 \\
Hymenoptera & Halictidae & 0.71 & 1.83 & 0.95 \\
Coleoptera & Mordellidae & 0.66 & 1.35 & 2.59 \\
Orthoptera & Acrididae & 0.98 & 1.19 & 0.09 \\
Orthoptera & Tettigoniidae & 0.79 & 0.74 & 0.35 \\
Mecoptera & Panorpidae & -0.84 & 0.67 & 0.37 \\
Hymenoptera & Tenthredinidae & -0.99 & 0.57 & 0.43 \\
Hymenoptera Vespidae & -0.67 & 0.52 & 0.07 \\
Araneae & Lycosidae & 0.74 & 0.51 & 0.12 \\
Hymenoptera & Megachilidae & 0.95 & 0.43 & 0.10 \\
Lepidoptera & Noctuidae & -0.95 & 0.39 & 0.24 \\
Coleoptera & Curculionidae & -0.70 & 0.24 & 1.13 \\
Diplopoda & Paradoxosomatidae & -0.94 & 0.23 & 0.10 \\
Hemiptera & Miridae & 0.66 & 0.23 & 0.82 \\
Diptera & Mycetophilidae & -0.77 & 0.17 & 0.60 \\
Orthoptera & Gryllidae & 0.77 & 0.14 & 0.04 \\
Lepidoptera & Tortricidae & -0.70 & 0.14 & 0.74 \\
Coleoptera & Scolytinae & 0.65 & 0.14 & 1.95 \\
Diptera & Cecidomyiidae & -0.79 & 0.11 & 2.88 \\
\hline & & & &
\end{tabular}




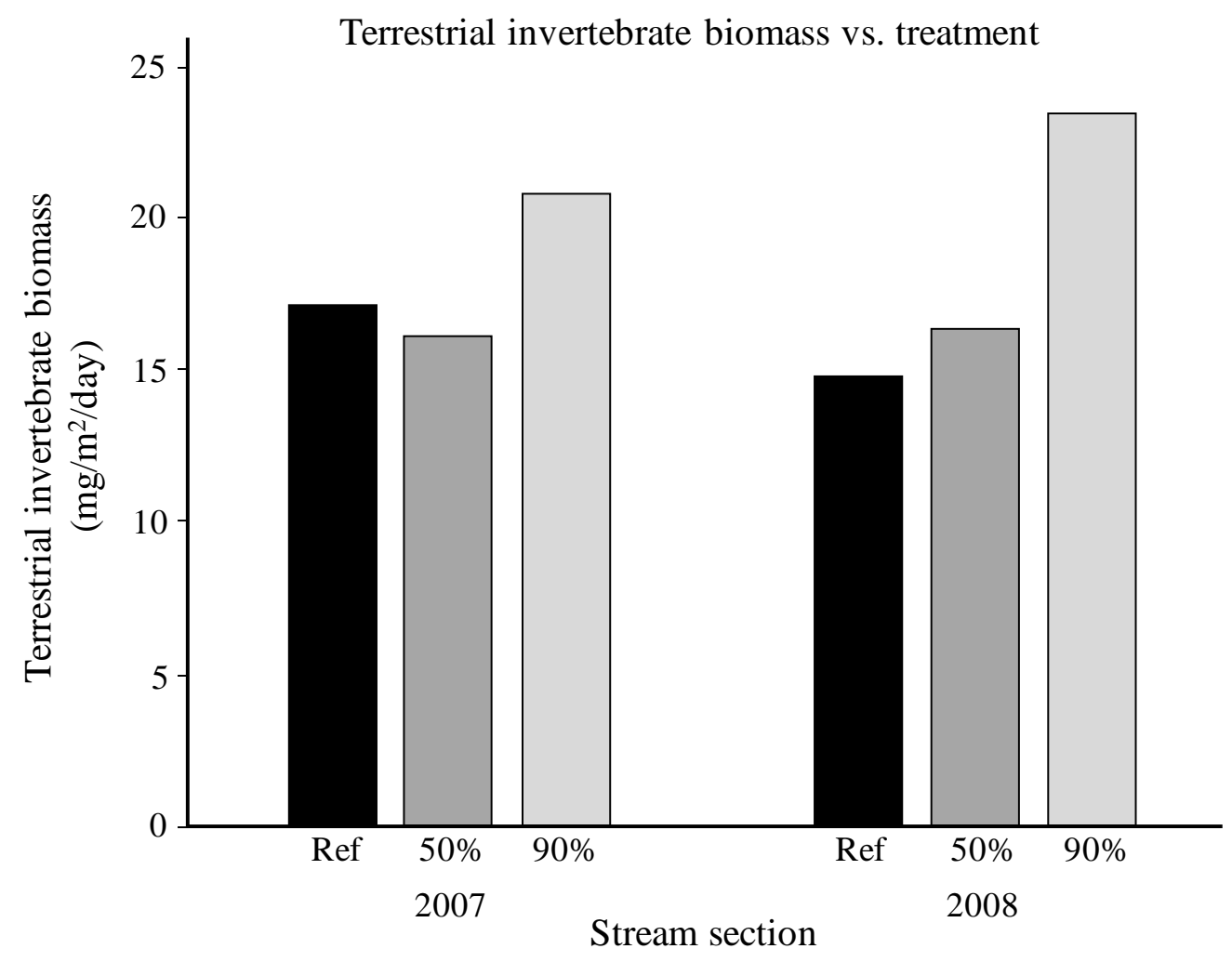

Figure 1. Differences were found in the TI biomass inputs into eight Appalachian headwater streams following riparian tree harvest. TI biomass inputs were significantly higher in the $90 \%$ basal removal sections when compared to reference sections (test performed with treatments averaged across years, $\mathrm{p}=0.018$ ). 

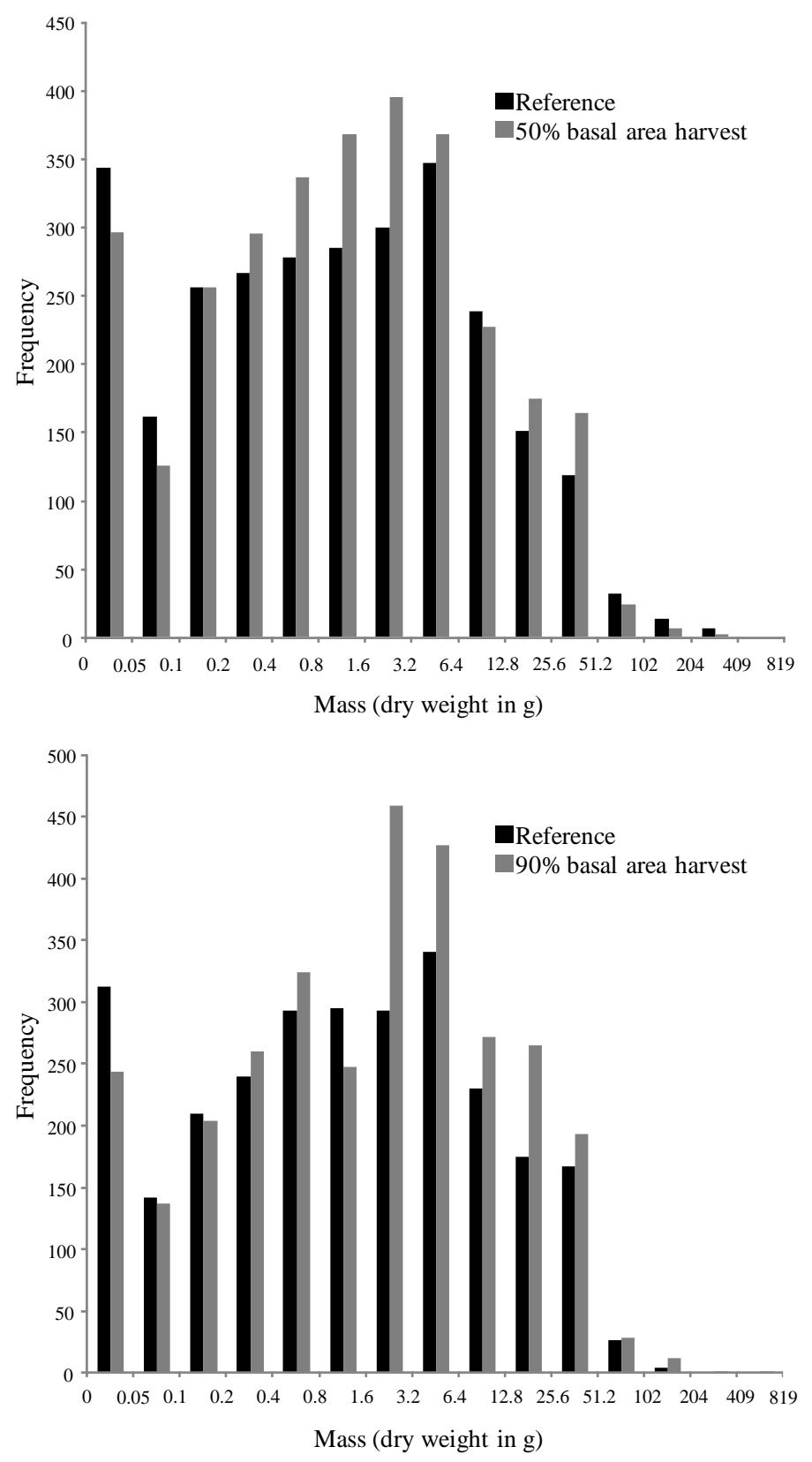

Figure 2. Weight frequencies of terrestrial invertebrate inputs into eight Appalachian headwater streams, comparing two levels of basal area harvest (BAH) to their corresponding reference areas. Average dry weights in the reference (combined), 50\%, and 90\% BAH treatments were $6.04 \mathrm{mg}, 6.00 \mathrm{mg}$, and $7.25 \mathrm{mg}$ respectively. Median dry weights in the reference (combined), $50 \%$, and $90 \%$ BAH treatments were $1.17 \mathrm{mg}, 1.21 \mathrm{mg}$, and $2.10 \mathrm{mg}$ respectively. 


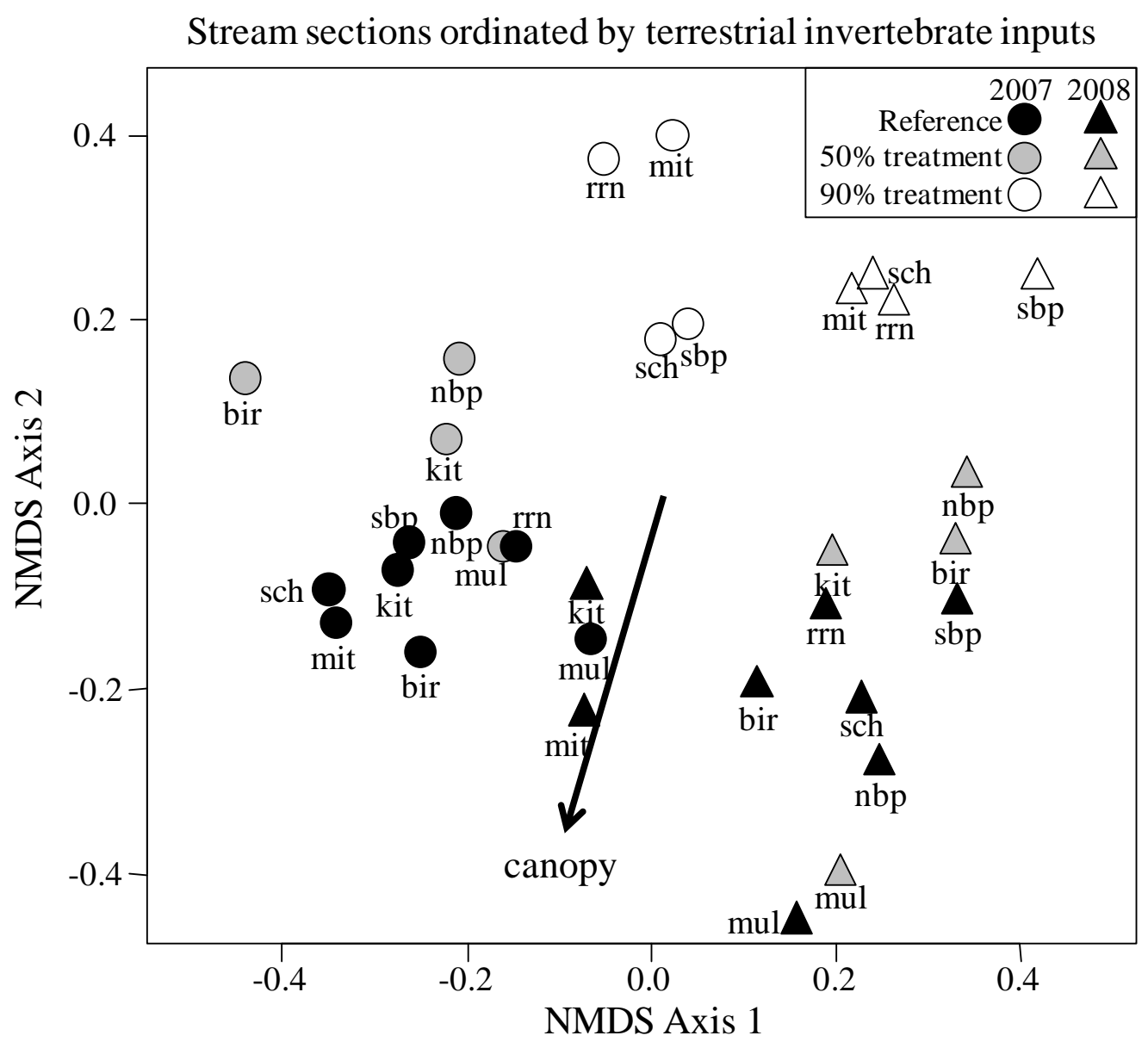

Figure 3. NMDS ordination of stream sections for both years, ordinated by composition of TI inputs into eight Appalachian headwater streams. The canopy vector indicates increasing canopy coverage. Riparian logging at $90 \%$ BAH produced significant changes in the TI input composition in 2007 and 2008. Natural annual variation in TI input composition significantly separated 2007 samples from 2008.

bir = Birch Run, kit = Kittle Creek, mit = Mitchell Creek, mul = Mulberry Run, nbp = North Branch Panther, rrn $=$ Rocky Run, $\mathrm{sch}=$ Schoolcraft Run, sbp $=$ South Branch Panther 


\section{References}

Allan, J. D. 1981. Determinants of diet of brook trout (Salvelinus fontinalis) in a mountain stream. Canadian Journal of Fisheries and Aquatic Sciences 38(2):184-192.

Allan, J. D., M. S. Wipfli, J. P. Caouette, A. Prussian, and J. Rodgers. 2003. Influence of streamside vegetation on inputs of terrestrial invertebrates to salmonid food webs. Canadian Journal of Fisheries and Aquatic Sciences 60(3):309-320.

Allen, K. R. 1951. The Horokiwi stream: a study of a trout population. New Zealand Marine Department Fisheries Bulletin 10:1-231.

Anderson, M. J. 2001. A new method for non-parametric multivariate analysis of variance. Austral Ecology 26:32-46.

Anderson, M. J. 2005. PERMANOVA: a FORTRAN computer program for permutational multivariate analysis of variance. Department of Statistics, University of Auckland, New Zealand.

Anderson, M. J., and C. J. F. ter Braak. 2003. Permutation tests for multi-factorial analysis of variance. Journal of Statistical Computation and Simulation 73:85-113.

Batzer, D. P., C. R. Jackson, and M. Mosner. 2000. Influences of riparian logging on plants and invertebrates in small, depressional wetlands of Georgia, U.S.A. Hydrobiologia 441(1):123-132.

Borror, D. J., C. A. Triplehorn, and N. F. Johnson. 1997. Introduction to the Study of Insects, 7th edition. Saunders College Publishing, Philadelphia.

Bray, J. R., and J. T. Curtis. 1957. An ordination of the upland forest communities of southern Wisconsin. Ecological Monographs 27:325-349.

Cada, G. F., J. M. Loar, and M. J. Sale. 1987. Evidence of food limitation of rainbow and brown trout in southern Appalachian soft-water streams. Transactions of the American Fisheries Society 116(5):692-702.

Cloe, W. W., III, and G. C. Garman. 1996. The energetic importance of terrestrial arthropod inputs to three warm-water streams. Freshwater Biology 36(1):105-114.

Duguay, J. P., P. B. Wood, and G. W. Miller. 2000. Effects of timber harvests on invertebrate biomass and avian nest success. Wildlife Society Bulletin 28(4):1123-1131.

Edwards, E. D., and A. D. Huryn. 1995. Annual contribution of terrestrial invertebrates to a New Zealand trout stream. New Zealand Journal of Marine and Freshwater Research 29(4):467-477.

Edwards, E. D., and A. D. Huryn. 1996. Effect of riparian land use on contributions of terrestrial invertebrates to streams. Hydrobiologia 337:1-3.

Gende, S. M., R. T. Edwards, M. F. Willson, and M. S. Wipfli. 2002. Pacific salmon in aquatic and terrestrial ecosystems. Bioscience 52:917-928.

Greenberg, C. H., and A. McGrane. 1996. A comparison of relative abundance and biomass of ground-dwelling arthropods under different forest management practices. Forest Ecology and Management 89:31-41.

Hynes, H. B. N. 1970. The Ecology of Running Waters. University of Toronto, Toronto.

Kawaguchi, Y., and S. Nakano. 2001. Contribution of terrestrial invertebrates to the annual resource budget for salmonids in forest and grassland reaches of a headwater stream. Freshwater Biology 46(3):303-316.

Kawaguchi, Y., Y. Taniguchi, and S. Nakano. 2003. Terrestrial invertebrate inputs determine the local abundance of stream fishes in a forested stream. Ecology 84(3):701-708. 
Lee, P., C. Smyth, and S. Boutin. 2004. Quantitative review of riparian buffer width guidelines from Canada to the United States. Journal of Environmental Management 70:165-180.

Mason, C. F., and S. M. Macdonald. 1982. The input of terrestrial invertebrates from tree canopies to a stream. Freshwater Biology 12(4):305-311.

McArdle, B. H., and M. J. Anderson. 2001. Fitting multivariate models to community data: a comment on distance-based redundancy analysis. Ecology 82:290-297.

McCune, B., and J. B. Grace. 2002. Analysis of Ecological Communities. mjm Software Design, Gleneden Beach, Oregon.

Muller, J., H. Bubler, and T. Kneib. 2008. Saproxylic beetle assemblages related to silvicultural management intensity and stand structures in a beech forest in Southern Germany. Journal of Insect Conservation 12:107-124.

Nakano, S., and coauthors. 1999a. Selective foraging on terrestrial invertebrates by rainbow trout in a forested headwater stream in northern Japan. Ecological Research 14(4):351-360.

Nakano, S., H. Miyasaka, and N. Kuhara. 1999b. Terrestrial-aquatic linkages: riparian arthropod inputs alter trophic cascades in a stream food web. Ecology 80(7):2435-2441.

Nakano, S., and M. Murakami. 2001. Reciprocal subsidies: dynamic interdependence between terrestrial and aquatic food webs. Proceedings of the National Academy of Sciences, USA 98(1):166-170.

Romaniszyn, E. D., J. J. Hutchens, and J. B. Wallace. 2007. Aquatic and terrestrial invertebrate drift in southern Appalachian Mountain streams: implications for trout food resources. Freshwater Biology 52(1):1-11.

Sabo, J. L., J. L. Bastow, and M. E. Power. 2002. Length-mass relationships for adult aquatic and terrestrial invertebrates in a California watershed. Journal of the North American Benthological Society 21(2):336-343.

Sage, R. D. 1982. Wet and dry-weight estimates of insects and spiders based on length. American Midland Naturalist 108:407-411.

Sample, B. E., R. J. Cooper, R. D. Greer, and R. C. Whitmore. 1993. Estimation of insect biomass by length and width. American Midland Naturalist 129(2):234-240.

Schoener, T. W. 1980. Length-weight regressions in tropical and temperate forest-understory insects. Annals of the Entomological Society of America 73:106-109.

Shure, D. J., and D. L. Phillips. 1991. Patch size of forest openings and arthropod populations. Oecologia 86(3):325-334.

Sweka, J. A., and K. J. Hartman. 2001. Fall and winter brook trout prey selection and daily ration. Source Proceedings of the Annual Conference of the Southeastern Association of Fish and Wildlife Agencies 55:8-22.

Sweka, J. A., and K. J. Hartman. 2008. Contribution of terrestrial invertebrates to yearly brook trout prey consumption and growth. Transactions of the American Fisheries Society 137(1):224-235.

Team, R. D. C. 2009. R: A language and environment for statistical computing, reference index version 2.9.1. R Foundation for Statistical Computing, Vienna.

Utz, R. 2005. Temporal trends in consumption, growth, and successful feeding traits of a central Appalachian brook trout population at the watershed scale. Master's Thesis, West Virginia University.

Utz, R. M., and K. J. Hartman. 2006. Temporal and spatial variation in the energy intake of a brook trout (Salvelinus fontinalis) population in an Appalachian watershed. Canadian Journal of Fisheries and Aquatic Sciences 63(12):2675-2686. 
Vannote, R. L., G. W. Minshall, K. W. Cummins, J. R. Sedell, and C. E. Cushing. 1980. The river continuum concept. Canadian Journal of Fisheries and Aquatic Sciences 37(1):130137.

Wallace, J. B., S. L. Eggert, and J. R. Webster. 1999. Effects of resource limitation on a detritalbased ecosystem. Ecological Monographs 69(4):409-442.

Webster, J. J., and K. J. Hartman. 2005. The role of terrestrial invertebrates in allopatric brook trout headwater streams in the central Appalachian Mountains. Journal of Freshwater Ecology 20(1):101-107.

Werner, S. M., and K. F. Raffa. 2000. Effects of forest management practices on the diversity of ground-occurring beetles in mixed northern hardwood forests of the Great Lakes Region. Forest Ecology and Management 139(1-3):135-155.

West Virginia Division of Foresty, 2005. West Virginia silvicultural best management practices for controlling soil erosion and sedimentation from logging operations. WVDOF-TR-053.

Wipfli, M. S. 1997. Terrestrial invertebrates as salmonid prey and nitrogen sources in streams: contrasting old-growth and young-growth riparian forests in southeastern Alaska, U.S.A. Canadian Journal of Fisheries and Aquatic Sciences 54(6):1259-1269.

Yi, H., and A. Moldenke. 2005. Response of ground-dwelling arthropods to different thinning intensities in young douglas fir forests of western Oregon. Environmental Entomology 34(5):1071-1080. 


\section{Appendix A}

List of terrestrial invertebrate taxa captured in pan traps along eight Appalachian headwater streams. Abundance values are individuals $/ \mathrm{m}^{2} /$ day. Biomass values are $\mathrm{mg} / \mathrm{m}^{2} /$ day. Taxa that were captured at $<0.01$ individuals $/ \mathrm{m}^{2} /$ day and $<0.01 \mathrm{mg} / \mathrm{m}^{2} /$ day were omitted.

$\mathrm{BAH}=$ basal area harvest

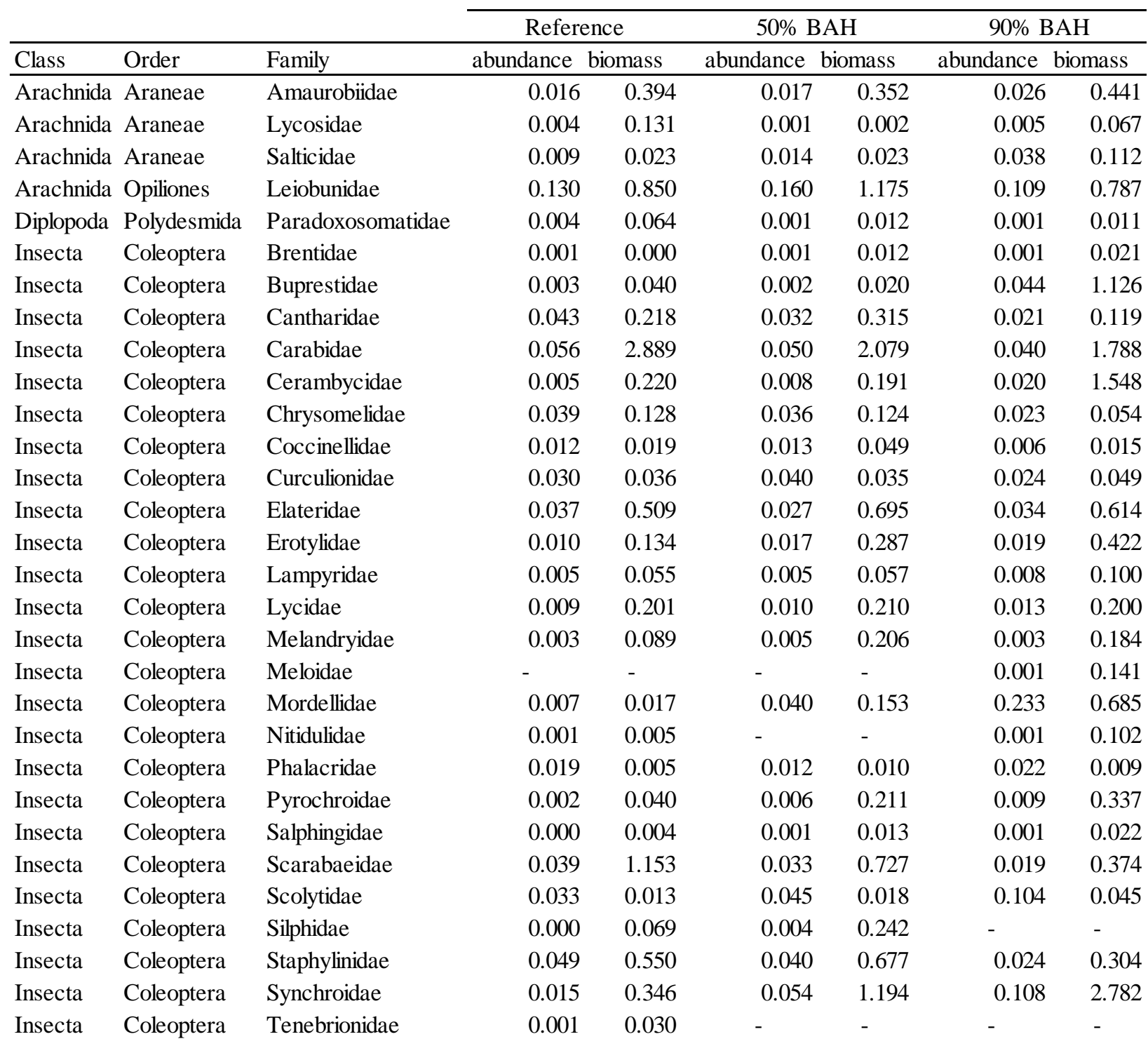


Appendix A (continued)

\begin{tabular}{|c|c|c|c|c|c|c|c|c|}
\hline \multirow{3}{*}{$\frac{\text { Class }}{\text { Insecta }}$} & \multirow{3}{*}{$\begin{array}{l}\text { Order } \\
\text { Diptera }\end{array}$} & \multirow{2}{*}{ Family } & \multicolumn{2}{|c|}{ Reference } & \multicolumn{2}{|c|}{$50 \% \mathrm{BAH}$} & \multicolumn{2}{|c|}{$90 \%$ BAH } \\
\hline & & & abundance & biomass & abundance & biomass & abundance & biomass \\
\hline & & Asilidae & 0.045 & 0.656 & 0.059 & 0.853 & 0.077 & 1.182 \\
\hline Insecta & Diptera & Athericidae & 0.004 & 0.021 & 0.012 & 0.117 & 0.009 & 0.036 \\
\hline Insecta & Diptera & Cecidomyidae & 0.268 & 0.020 & 0.220 & 0.016 & 0.172 & 0.015 \\
\hline Insecta & Diptera & Dolichopodidae & 0.009 & 0.004 & 0.016 & 0.010 & 0.008 & 0.005 \\
\hline Insecta & Diptera & Empididae & 0.043 & 0.074 & 0.052 & 0.053 & 0.056 & 0.047 \\
\hline Insecta & Diptera & Heleomyzidae & 0.038 & 0.011 & 0.028 & 0.009 & 0.012 & 0.002 \\
\hline Insecta & Diptera & Muscidae & 0.020 & 0.075 & 0.013 & 0.044 & 0.014 & 0.042 \\
\hline Insecta & Diptera & Mycetophilidae & 0.018 & 0.031 & 0.022 & 0.035 & 0.007 & 0.014 \\
\hline Insecta & Diptera & Sciaridae & 0.110 & 0.052 & 0.108 & 0.039 & 0.119 & 0.068 \\
\hline Insecta & Diptera & Syrphidae & 0.003 & 0.010 & 0.001 & 0.003 & 0.005 & 0.020 \\
\hline Insecta & Diptera & Tipulidae & 0.019 & 0.155 & 0.014 & 0.114 & 0.008 & 0.049 \\
\hline Insecta & Hemiptera & Aphididae & 0.073 & 0.005 & 0.074 & 0.006 & 0.130 & 0.010 \\
\hline Insecta & Hemiptera & Cercopidae & 0.031 & 0.054 & 0.047 & 0.093 & 0.051 & 0.056 \\
\hline Insecta & Hemiptera & Cicadellidae & 0.130 & 0.306 & 0.105 & 0.218 & 0.079 & 0.170 \\
\hline Insecta & Hemiptera & Coreidae & 0.001 & 0.061 & - & - & 0.001 & 0.002 \\
\hline Insecta & Hemiptera & Membracidae & 0.006 & 0.030 & 0.006 & 0.025 & 0.015 & 0.043 \\
\hline Insecta & Hemiptera & Miridae & 0.020 & 0.036 & 0.023 & 0.036 & 0.028 & 0.037 \\
\hline Insecta & Hemiptera & Pentatomidae & 0.009 & 0.046 & 0.015 & 0.039 & 0.011 & 0.058 \\
\hline Insecta & Hemiptera & Reduviidae & 0.013 & 0.058 & 0.016 & 0.058 & 0.004 & 0.015 \\
\hline Insecta & Hymenoptera & Apiidae & 0.005 & 0.129 & 0.006 & 0.189 & 0.020 & 0.657 \\
\hline Insecta & Hymenoptera & Braconidae & 0.013 & 0.051 & 0.011 & 0.048 & 0.011 & 0.040 \\
\hline Insecta & Hymenoptera & Formicidae & 0.143 & 0.708 & 0.123 & 0.555 & 0.299 & 1.414 \\
\hline Insecta & Hymenoptera & Halictidae & 0.008 & 0.085 & 0.020 & 0.197 & 0.068 & 0.818 \\
\hline Insecta & Hymenoptera & Ichneumonidae & 0.018 & 0.254 & 0.034 & 0.552 & 0.016 & 0.219 \\
\hline Insecta & Hymenoptera & Megachilidae & 0.000 & 0.007 & 0.004 & 0.107 & 0.007 & 0.158 \\
\hline Insecta & Hymenoptera & Tenthredinidae & 0.002 & 0.064 & 0.004 & 0.056 & 0.002 & 0.032 \\
\hline Insecta & Hymenoptera & Tenthredinidae & 0.013 & 0.063 & 0.008 & 0.011 & 0.003 & 0.016 \\
\hline Insecta & Hymenoptera & Vespidae & 0.003 & 0.136 & 0.001 & 0.032 & 0.001 & 0.031 \\
\hline Insecta & Lepidoptera & Arctiidae & 0.017 & 0.105 & 0.012 & 0.102 & 0.006 & 0.019 \\
\hline Insecta & Lepidoptera & Geometridae & 0.026 & 0.154 & 0.022 & 0.128 & 0.017 & 0.084 \\
\hline Insecta & Lepidoptera & Noctuidae & 0.010 & 0.093 & 0.006 & 0.047 & 0.001 & 0.017 \\
\hline Insecta & Lepidoptera & Notodontidae & 0.094 & 0.648 & 0.087 & 0.625 & 0.068 & 0.524 \\
\hline Insecta & Lepidoptera & Tortricidae & 0.010 & 0.008 & 0.056 & 0.067 & 0.006 & 0.006 \\
\hline Insecta & Mecoptera & Bittacidae & 0.001 & 0.018 & 0.001 & 0.013 & - & - \\
\hline Insecta & Mecoptera & Panorpidae & 0.013 & 0.138 & 0.009 & 0.110 & 0.005 & 0.051 \\
\hline Insecta & Orthoptera & Acrididae & 0.001 & 0.014 & 0.004 & 0.223 & 0.005 & 0.519 \\
\hline Insecta & Orthoptera & Gryllidae & 0.001 & 0.032 & 0.001 & 0.010 & 0.001 & 0.016 \\
\hline Insecta & Orthoptera & Rhaphidophoridae & 0.040 & 1.613 & 0.023 & 0.600 & 0.019 & 0.693 \\
\hline Insecta & Orthoptera & Tettigoniidae & - & - & 0.007 & 0.094 & 0.032 & 0.385 \\
\hline Insecta & Psocoptera & Psocidae & 0.124 & 0.063 & 0.137 & 0.064 & 0.130 & 0.076 \\
\hline Insecta & Thysanoptera & Phlaeothripidae & 0.015 & 0.006 & 0.016 & 0.006 & 0.024 & 0.010 \\
\hline
\end{tabular}


Chapter 5: The effects of riparian logging and woody debris additions on aquatic invertebrates in forested headwater streams

Jered M. Studinski

\begin{abstract}
Aquatic invertebrates (AI's) in forested headwater streams are strongly influenced by the adjacent riparian area. Logging modifies the products and services of riparian areas, and the effects of riparian logging on AI communities has been the focus of much recent research. However, across regions, consistent responses have not been found. The impacts of riparian logging are most likely region-specific, and depend on factors such as latitude, elevation, and intensity of disturbance. This study quantified the effects of riparian logging and large woody debris (LWD) additions on AI communities in eight streams in central West Virginia. The treatments consisted of $0 \%, 50 \%$, and $90 \%$ basal area removal sections. LWD was added to one treatment section within each stream.

The treatments did not affect AI biomass, abundance, richness, or community composition. The lack of a short-term AI response to the treatments suggests that AI's may be insensitive to locally intense, but spatially limited riparian disturbances. Additionally, natural annual variation and possible top-down trophic effects by predators may have masked significant treatment effects.
\end{abstract}




\section{Introduction}

Aquatic invertebrate (AI) communities in forested headwater streams are strongly influenced by the riparian area. Allochthonous detritus forms the base of forested stream food webs (Vannote et al. 1980; Wallace et al. 1999), while large woody debris (LWD) increases habitat complexity and aids in detrital retention and storage (Bilby 1981; Harmon et al. 1986; Raikow et al. 1995). Riparian canopy shades streams, regulating temperature while also limiting primary productivity (Kiffney et al. 2003; Quinn et al. 1997). The riparian area also acts as a filter and buffer, catching sediment and reducing the effects of watershed disturbance (Keller and Swanson 1979; Naiman and Decamps 1997).

Riparian logging is reported to affect AI communities by altering their energy sources and habitat. The loss of canopy reduces shading, which leads to stream warming and increased primary productivity (Kiffney et al. 2003; Quinn et al. 1997). AI communities respond with a reduction in cold-water taxa (Sweeney et al. 1986), a reduction in shredders (Stone and Wallace 1998), and an increase in grazers (Nislow and Winsor 2006; Stone and Wallace 1998). Riparian logging reduces long-term LWD inputs (Flebbe and Dolloff 1995; Richmond and Fausch 1995; Silsbee and Larson 1983). This can lead AI community shifts due to reduced detrital retention and habitat complexity (Hilderbrand et al. 1997). Roads and log landings associated with logging operations increases sedimentation rates (Jones et al. 1999; Kochenderfer et al. 1997; Swank et al. 2001). Increases in fine sediment can result in losses of Ephemeroptera, Plecoptera, and Trichoptera taxa (Kaller and Hartman 2004).

Best management practices (BMP's) have been developed to minimize the impacts of riparian timber harvest on streams. Within the U.S.A., actual guidelines and requirements vary by region and state (Lee et al. 2004). The main component of these guidelines is the 
establishment of a streamside management zone (SMZ). The SMZ is a riparian buffer within which disturbance is limited. West Virginia Division of Forestry (WVDF) BMP's require a road-free SMZ that is at least $30 \mathrm{~m}$ wide for perennial and intermittent streams (West Virginia Division of Forestry 2005). Within the SMZ there is no harvest limit, but the operation of large equipment in this area is to be avoided. West Virginia BMP's require the removal of any LWD that may enter a stream during logging operations. The WVDF does, however, recognize that LWD is important in stream ecology (West Virginia Division of Forestry 2005). Following logging, proper reclamation techniques are required, including seeding and mulching exposed soil.

The response of AI communities to riparian logging varies greatly but may be consistent within similar latitudes and elevations (Richardson 2008). Research on the effects of riparian logging is needed in areas like central Appalachia where timber harvesting is economically important. This study documented the effects of varying levels of riparian timber harvest on AI communities. Additionally, the effects of LWD additions on AI's were investigated.

\section{Methods}

Study area

For information on study area, see chapter two.

\section{Stream variables}

Canopy, LWD, temperature, and sedimentation data were collected at various times during the study. A full description of the methods involved can be found in chapter two. Periphyton 
sampling was performed in 2008. A full description of the methods involved can be found in chapter three.

\section{Aquatic invertebrates}

AI's were sampled in early April 2006, prior to riparian logging, and in early April 2007 and 2008, both post-harvest. Kittle Creek, a 50\% basal area harvest (BAH) stream, was harvested one week prior to AI sampling in 2007. Due to this, the 2007 Kittle Creek data were removed from analyses.

AI's were collected using a slack sampler (500 $\mu \mathrm{m}$ mesh, $0.25 \mathrm{~m}^{2}$ sample area). Ten samples were collected from riffles throughout each of the three sections of the streams (harvest, harvest+LWD, reference), and preserved in 80\% ethanol. Samples from 2006 and 2007 were fully sorted, while samples from 2008 were each split by volume prior to sorting. All AI's were identified to genus, except Chironomidae, which were identified as either Tanypodinae or nonTanypodinae chironomids (Merritt and Cummins 1996; Merritt et al. 2008; Peckarsky et al. 1990). Body lengths were recorded for each specimen, and length-weight regressions were used to calculate dry weight in mg (Benke et al. 1999; Sample et al. 1993). AI's were assigned to functional feeding groups following Merritt et al. (2008).

Two-way repeated measures ANOVA was used to test for differences in AI abundance, biomass, and richness over time and between treatments and their corresponding reference areas. Crayfish (Cambaridae) biomass was analyzed separately. Repeated measures ANOVA was also used to test for a grazer and shredder response to the treatments. Regression analysis tested for a relationship between periphyton biomass and grazer abundance. 
Community analysis was performed using permutational multivariate analysis of variance (PerMANOVA)(Anderson 2001; Anderson 2005; McArdle and Anderson 2001) which used AI taxa abundances to analyze changes in stream sections between treatments and over time. Since PerMANOVA requires a balanced data set, streams were grouped by BAH intensity. Sections were coded as reference, harvest, and harvest+LWD, and data were analyzed across 2006, 2007, and 2008. To utilize data from Kittle Creek, a third PerMANOVA investigated changes in all four streams which received a 50\% BAH treatment and compared 2006 to 2008. For all PerMANOVA's, sites were fixed factors nested within years. Since there was no replication at the stream level, samples could not be nested within streams. Stream was included as a covariable. Data were $\ln (\mathrm{x}+1)$ transformed, and the analyses were based on Bray-Curtis dissimilarities (Bray and Curtis 1957). Permutation of residuals occurred under the reduced model, with 9,999 permutations for all calculated p-values. Bray-Curtis dissimilarity measure is robust to ecological data (McCune and Grace 2002), while permutation under a reduced model gives the best power (Anderson and ter Braak 2003). To aid the interpretation of the community

analysis, samples were ordinated by taxa abundance using non-metric multidimensional scaling (NMDS) with overlying treatment vectors. Program R (R Development Core Team 2009) was used for all univariate data analyses and NMDS. The program PERMANOVA (Anderson 2005) was used for the PerMANOVA.

\section{Results}

Some habitat variables were significantly affected by riparian timber harvesting. Canopy cover decreased with increasing harvest intensity. In-stream LWD was higher in the LWD treatment sections. Stream temperature and periphyton biomass increased with increasing harvest 
intensity. Sedimentation rates did not respond to the treatments. In-depth results and interpretation of these variables can be found in chapters two and three.

The treatments had no effect on basic AI metrics. Across all streams and years 89,576 individuals from 76 taxa were collected, identified, and measured. Riparian harvest intensity and LWD addition had no significant effect on AI abundance, biomass, or richness (Table 1).

Significant natural variation of basic AI metrics was observed. AI biomass, abundance, and richness were all significantly affected by year (Table 2). Post-hoc analyses indicate that AI biomass and abundance was significantly higher in 2007 and richness was significantly lower in 2008.

Whole-community multivariate analyses indicated that AI communities were affected more by year than by the treatments. Canopy removal and LWD additions had no effect on AI communities (50\% BAH streams $\mathrm{p}=0.999,90 \%$ BAH streams $\mathrm{p}=0.999$ [Table 3]). The PerMANOVA that included Kittle Creek was similar, with no treatment effect detected $(\mathrm{p}=0.987)$. The effect of year on AI communities was more evident (50\% BAH streams $\mathrm{p}=0.281,90 \% \mathrm{BAH}$ streams $\mathrm{p}=0.002$ [Table 3]), with the post-hoc analysis of the $90 \% \mathrm{BAH}$ streams indicating significant community differences between all three years $(\mathrm{p} \leq 0.034)$. Stream was significant as a covariable in some of the models (50\% BAH streams $\mathrm{p}=0.250,90 \% \mathrm{BAH}$ streams $\mathrm{p}=0.045$ [Table 3]). The NMDS ordination of sites by AI abundance supports the PerMANOVA results (Figure 1). Sites were loosely aggregated by year and stream, but not by treatment.

Some functional feeding guild responses were observed. Proportional shredder abundance was not affected by the basal removal treatments $(\mathrm{p}=0.856)$. Proportional grazer abundance was not affected by the basal area removal treatments $(\mathrm{p}=0.417)$. A more-direct 
relationship between proportional grazer abundance and periphyton biomass indicated a weak, but statistically significant relationship $\left(\mathrm{p}=0.048, \mathrm{R}^{2}=0.311\right.$ [Figure 2]).

\section{Discussion}

The lack of a local, short-term AI response to the treatments suggests that AI's may be insensitive to intense but spatially limited riparian disturbances. Unlike most logging operations, in this study the watershed outside the riparian treatments remained undisturbed. Additionally, responses to the treatments may have occurred in the unsampled areas downstream from the experimental sections. Natural variation, small treatment areas, and predation may have masked and dampened treatment responses.

Yearly variation in basic AI metrics is caused by many factors (Vinson and Hawkins 1998). In this project's streams, AI abundances tripled and biomass doubled in 2007, independent of their treatments. Unknown and unmeasured variables were important in determining AI biomass, but mechanisms of natural fluctuations in AI abundance were outside the scope of this study. The AI sampling methodology, in which AI's were sampled from all streams during the first weekend in April, may have attributed to the yearly variation. The comparison of AI communities at the same point in time ignored annual variation in factors like cumulative degree days, possibly magnifying the effect of year on AI communities. Explaining the effect of year on richness is more straightforward, as the significant decrease in richness in 2008 can be attributed to changing the sampling protocol and splitting samples prior to sorting.

AI communities appear to be resistant to intense but spatially limited disturbances. Other researchers have found increased effects of logging on AI communities as logging area and intensity increased (Davies and Nelson 1994; Kiffney et al. 2003; Kreutzweiser et al. 2004; 
Quinn et al. 2004). In this study, clear community shifts were not observed, possibly due in part to the limited extent of the riparian logging (1.5 ha). Through pre- and post-harvest year, withinstream variation in AI communities remained lower than between-stream or between-year variation. Various aspects of this study's design, coupled with robust AI communities, made detecting treatment effects difficult.

The timing of AI collection may have influenced the results. AI's were sampled in early April, a time with consistent flows and high AI abundance and richness (Merritt et al. 2008). However, cool conditions, the short time since leaf-fall, and pre-leaf-out conditions meant the environments of treatments and reference sections were more-similar than at other times of the year. Sampling AI's in late summer, a time with potentially greater between-treatment variation in periphyton biomass, stream temperature, and detrital limitations, may have resulted in observations of a treatment response by AI's. However, low-flow or no-flow conditions, which can occur in these streams from late spring to fall, would have made sampling difficult.

Expecting shredders to respond to the treatments may be unrealistic. The riparian disturbance extended $30 \mathrm{~m}$ from the stream, and AI samples were collected evenly throughout the $250-\mathrm{m}$ section. The nearest source of allochthonous materials was $30 \mathrm{~m}$ laterally or, on average, $125 \mathrm{~m}$ upstream. Additionally, increases of in-stream LWD may have increased retention of allochthonous materials (Dobson and Hildrew 1992; Webster et al. 1994). Data indicate that following logging, in-stream LWD increased in both the harvested and harvested+LWD sections (see chapter 3). This may have increased detrital retention and minimized the impacts of decreased detrital sources.

Relating grazer abundance to the treatments was difficult. Although chapter three reported that periphyton biomass was significantly higher in the $90 \% \mathrm{BAH}$ treatment sections, 
there was no significant relationship between grazer abundance and treatment. The more-direct relationship between grazer abundance and canopy coverage was statistically significant, but weak $\left(p=0.048, R^{2}=0.311\right)$. Weak interactions between periphyton biomass and invertebrate communities has been observed by other researchers (Kishi et al. 2004; Quinn et al. 1997). Further confounding the results, the biomass and behavior of grazers can be affected by predation by salmonids (McIntosh and Townsend 1996; Nakano et al. 1999), which can exhibit an important top-down control and dampen the effects of increased periphyton.

All streams in this study were treated with limestone sand but the AI communities may have remained limited by acidic conditions and structured by their proximity to the sand treatments. McClurg et al. (2007) found that AI communities were dependent upon the proximity to the limestone sand treatment and that full recovery generally did not occur. This limitation may have prevented a response to riparian and LWD treatments.

The short-term effects of riparian logging in small areas (1.5 ha) on AI's seem negligible. This study does not, however, speak to the cumulative effects of basin-wide logging, and extrapolation of these data outside this relatively small area is not recommended. Within Appalachia, further research involving the detection of AI response thresholds to disturbance would be of great utility. Increasing the number of samples (streams), increasing treatment size, and sampling AI's during more-stressful conditions in late summer may reveal clearer AI responses to riparian logging. Additionally, an understanding of the mechanisms affecting natural annual variation in AI populations would be of great utility to stream ecologists. 
Table 1. Comparing each treatment to its corresponding reference section both pre- and postharvest, riparian harvesting intensity had no effect on basic AI metrics in seven Appalachian headwater streams.

\begin{tabular}{lrr}
\hline & $\begin{array}{r}\text { Basal } \\
\text { removal }\end{array}$ & $\begin{array}{r}\text { treatment } \mathrm{x} \\
\text { year effect }\end{array}$ \\
\hline \multirow{3}{*}{ Abundance } & $\begin{array}{r}50 \% \\
\text { Biomass }\end{array}$ & $\mathrm{p}=0.814$ \\
& $90 \%$ & $\mathrm{p}=0.913$ \\
& $50 \%$ & $\mathrm{p}=0.377$ \\
Crayfish & $50 \%$ & $\mathrm{p}=0.888$ \\
biomass & $90 \%$ & $\mathrm{p}=0.181$ \\
& $50 \%$ & $\mathrm{p}=0.079$ \\
Richness & $90 \%$ & $\mathrm{p}=0.783$ \\
&
\end{tabular}


Table 2. Mean AI abundance, biomass (not including crayfish), and richness across all sections for each year. Natural annual variation significantly affected basic AI's metrics. * indicates significantly different values

\begin{tabular}{lrccr}
\cline { 2 - 5 } & 2006 & 2007 & 2008 & year effect \\
\hline abundance (per m2) & 312.4 & $976.8 *$ & 296.0 & $\mathrm{p}<0.001$ \\
biomass (mg/m2) & 398.0 & $846.8 *$ & 432.8 & $\mathrm{p}<0.001$ \\
richness (taxa per section) & 33.8 & 34.2 & $28.8 *$ & $\mathrm{p}<0.001$ \\
\hline
\end{tabular}


Table 3. PerMANOVA results of tests for community differences in 7 Appalachian headwater streams (4 with $90 \% \mathrm{BAH}, 3$ with $50 \% \mathrm{BAH}$ ). Natural annual variation had a much greater affect than the treatments on AI communities. Stream was a significant covariable for the streams with $90 \%$ BAH treatment sections.

\begin{tabular}{lcc}
\cline { 2 - 3 } & 2006-2008 covariable (stream) \\
\hline $50 \%$, treatment effect & $\mathrm{p}=0.999$ & $\mathrm{p}=0.250$ \\
year effect & $\mathrm{p}=0.281$ & \\
\hline $\begin{array}{l}\text { 90\%, treatment effect } \\
\text { year effect }\end{array}$ & $\mathrm{p}=0.999$ & $\mathrm{p}=0.045$ \\
\hline
\end{tabular}




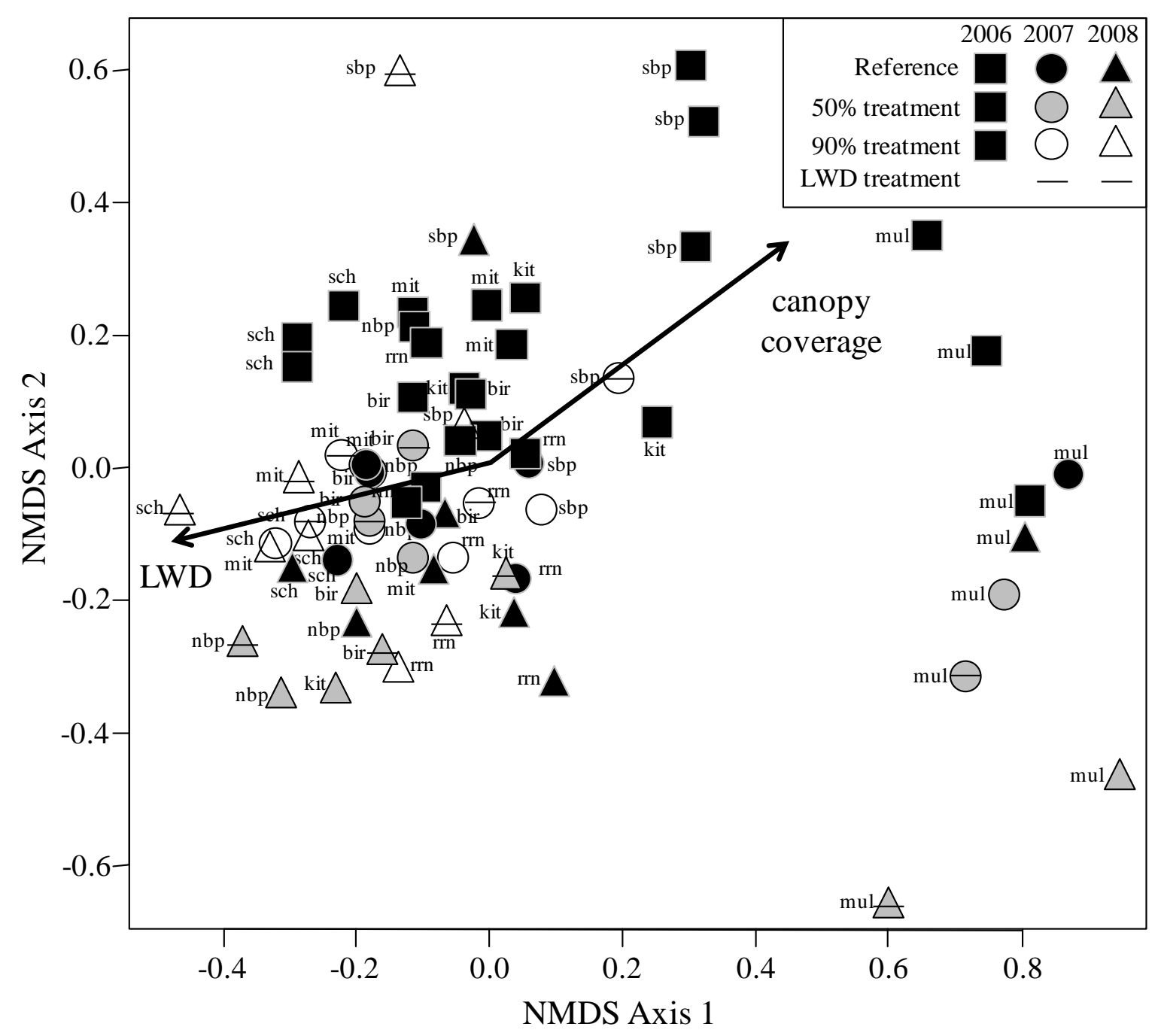

Figure 1. NMDS ordination of sections from eight Appalachian headwater streams by AI abundance. LWD and canopy coverage vectors indicate increasing values. The 2006 data represents pre-treatment conditions. For 2007 and 2008 data, tighter aggregations by shape rather than color indicate a stronger effect of natural yearly variation over the effect of the treatments.

bir $=$ Birch Run, kit $=$ Kittle Creek, mit $=$ Mitchell Creek, mul = Mulberry Run, nbp = North Branch Panther, rrn = Rocky Run, $\mathrm{sch}=$ Schoolcraft Run, sbp $=$ South Branch Panther 


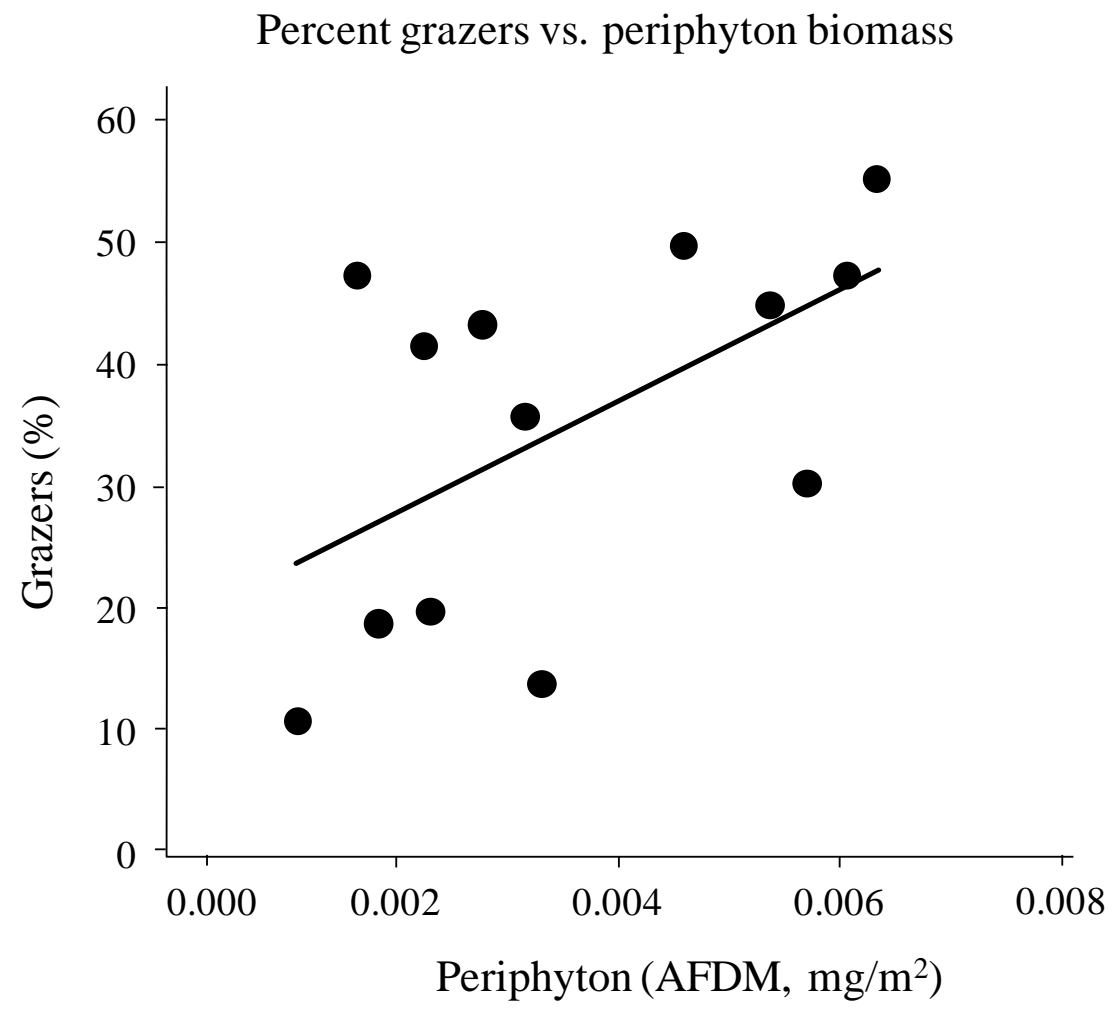

Figure 2. A significant relationship was detected between grazer abundance and periphyton biomass in seven Appalachian headwater streams $\left(\mathrm{p}=0.048, \mathrm{R}^{2}=0.311\right)$. Regression line: $\mathrm{y}=$ $4600.5 x+18.544$ 


\section{References}

Anderson, M. J. 2001. A new method for non-parametric multivariate analysis of variance. Austral Ecology 26:32-46.

Anderson, M. J. 2005. PERMANOVA: a FORTRAN computer program for permutational multivariate analysis of variance. Department of Statistics, University of Auckland, New Zealand.

Anderson, M. J., and C. J. F. ter Braak. 2003. Permutation tests for multi-factorial analysis of variance. Journal of Statistical Computation and Simulation 73:85-113.

Benke, A. C., A. D. Huryn, L. A. Smock, and J. B. Wallace. 1999. Length-mass relationships for freshwater macroinvertebrates in North America with particular reference to the southeastern United States. Journal of the North American Benthological Society 18(3):308-343.

Bilby, R. E. 1981. Role of organic debris dams in regulating the export of dissolved and particulate matter from a forested watershed. Ecology 62:1234-1243.

Bray, J. R., and J. T. Curtis. 1957. An ordination of the upland forest communities of southern Wisconsin. Ecological Monographs 27:325-349.

Davies, P. E., and M. Nelson. 1994. Relationships between riparian buffer widths and the effects of logging on stream habitat, invertebrate community composition and fish abundance. Australian Journal of Marine and Freshwater Research 45(7):1289-1305.

Dobson, M., and A. G. Hildrew. 1992. A test of resource limitation among shredding detritivores in low order streams in southern England. Journal of Animal Ecology 61:69-77.

Flebbe, P. A., and C. A. Dolloff. 1995. Trout use of woody debris and habitat in Appalachian wilderness streams of North Carolina. North American Journal of Fisheries Management 15(3):579-590.

Harmon, M. E., and coauthors. 1986. Ecology of coarse woody debris in temperate ecosystems. Advances in Ecological Research 15:133-302.

Hilderbrand, R. H., A. D. Lemly, C. A. Dolloff, and K. L. Harpster. 1997. Effects of large woody debris placement on stream channels and benthic macroinvertebrates. Canadian Journal of Fisheries and Aquatic Sciences 54(4):931-939.

Jones, E. B. D., III, G. S. Helfman, J. O. Harper, and P. V. Bolstad. 1999. Effects of riparian forest removal on fish assemblages in southern Appalachian streams. Conservation Biology 13(6):1454-1465.

Kaller, M., and K. Hartman. 2004. Evidence of a threshold level of fine sediment accumulation for altering benthic macroinvertebrate communities. Hydrobiologia 518:1-3.

Keller, J. R., and F. J. Swanson. 1979. Effects of large organic material on channel form and fluvial processes. Earth Surface Processes 4:361-380.

Kiffney, P. M., J. S. Richardson, and J. P. Bull. 2003. Responses of periphyton and insects to experimental manipulation of riparian buffer width along forest streams. Journal of Applied Ecology 40(6):1060-1076.

Kishi, D., M. Murakami, S. Nakano, and Y. Taniguchi. 2004. Effects of forestry on the thermal habitat of Dolly Varden (Salvelinus malma). Ecological Research 19:283-290.

Kochenderfer, J. N., P. J. Edwards, and F. Wood. 1997. Hydrologic impacts of logging an Appalachian watershed using West Virginia's best management practices. Northern Journal of Applied Forestry 14:207-218. 
Kreutzweiser, D. P., S. S. Capell, and F. D. Beall. 2004. Effects of selective forest harvesting on organic matter inputs and accumulation in headwater streams. Northern Journal of Applied Forestry 21(1):19-30.

Lee, P., C. Smyth, and S. Boutin. 2004. Quantitative review of riparian buffer width guidelines from Canada to the United States. Journal of Environmental Management 70:165-180.

McArdle, B. H., and M. J. Anderson. 2001. Fitting multivariate models to community data: a comment on distance-based redundancy analysis. Ecology 82:290-297.

McClurg, S. E., J. T. Petty, P. M. Mazik, and J. C. Clayton. 2007. Stream ecosystem response to limestone treatment in acid impacted watersheds of the Allegheny Plateau. Ecological Applications 17(4):1087-1104.

McCune, B., and J. B. Grace. 2002. Analysis of Ecological Communities. mjm Software Design, Gleneden Beach, Oregon.

McIntosh, A. R., and C. R. Townsend. 1996. Interactions between fish, grazing invertebrates and algae in a New Zealand stream: a trophic cascade mediated by fish-induced changes to grazer behaviour? Oecologia 108(1):174-181.

Merritt, R. W., and K. W. Cummins. 1996. An introduction to the aquatic insects of North America, 3rd edition edition. Kendall/Hunt, Dubuque, Iowa.

Merritt, R. W., K. W. Cummins, and M. B. Berg. 2008. An Introduction to the Aquatic Insects of North America, 4 edition. Kendall Hunt, Dubuque, Iowa.

Naiman, R. J., and H. Decamps. 1997. The ecology of interfaces: riparian zones. Annual Review of Ecology and Systematics 28:621-658.

Nakano, S., H. Miyasaka, and N. Kuhara. 1999. Terrestrial-aquatic linkages: riparian arthropod inputs alter trophic cascades in a stream food web. Ecology 80(7):2435-2441.

Nislow, K. H., and H. L. Winsor. 2006. Influences of logging history and riparian forest characteristics on macroinvertebrates and brook trout (Salvelinus fontinalis) in headwater streams (New Hampshire, U.S.A.). Freshwater Biology 51(2):388-397.

Peckarsky, B. L., P. R. Fraissinet, M. A. Penton, and D. J. Conklin. 1990. Freshwater Macroinvertebrates of Northeastern North America. Cornell University Press, Ithaca, NY.

Quinn, J. M., I. K. J. Boothroyd, and B. J. Smith. 2004. Riparian buffers mitigate effects of pine plantation logging on New Zealand streams 2. Invertebrate communities. Forest Ecology and Management 191(1-3):129-146.

Quinn, J. M., A. B. Cooper, M. J. Stroud, and G. P. Burrell. 1997. Shade effects on stream periphyton and invertebrates: An experiment in streamside channels. New Zealand Journal of Marine and Freshwater Research 31(5):665-683.

Raikow, D. F., S. A. Grubbs, and K. W. Cummins. 1995. Debris dam dynamics and coarse particulate organic matter retention in an Appalachian mountain stream. Journal of the North American Benthological Society 14(4):535-546.

Richardson, J. S. 2008. Aquatic arthropods and forestry: effects of large-scale land use on aquatic systems in Nearctic temperate regions. The Canadian Entomologist 104(4):495509.

Richmond, A. D., and K. D. Fausch. 1995. Characteristics and function of large woody debris in subalpine Rocky Mountain streams in northern Colorado. Canadian Journal of Fisheries and Aquatic Sciences 52(8):1789-1802.

Sample, B. E., R. J. Cooper, R. D. Greer, and R. C. Whitmore. 1993. Estimation of insect biomass by length and width. American Midland Naturalist 129(2):234-240. 
Silsbee, D. G., and G. L. Larson. 1983. A comparison of streams in logged and unlogged areas of Great Smoky Mountains National Park. Hydrobiologia 102(2):99-111.

Stone, M. K., and J. B. Wallace. 1998. Long-term recovery of a mountain stream from clear-cut logging: The effects of forest succession on benthic invertebrate community structure. Freshwater Biology 39(1):151-169.

Swank, W. T., J. M. Vose, and K. J. Elliott. 2001. Long-term hydrologic and water quality responses following commercial clearcutting of mixed hardwoods on a southern Appalachian catchment. Forest Ecology and Management 143:1-3.

Sweeney, B. W., R. L. Vannote, and P. J. Dodds. 1986. The relative importance of temperature and diet to larval development and adult size of the winter stonefly, Soyedina carolinensis (Plectoptera: Nemouridae). Freshwater Biology 16:39-48.

Team, R. D. C. 2009. R: A language and environment for statistical computing, reference index version 2.9.1. R Foundation for Statistical Computing, Vienna.

Vannote, R. L., G. W. Minshall, K. W. Cummins, J. R. Sedell, and C. E. Cushing. 1980. The river continuum concept. Canadian Journal of Fisheries and Aquatic Sciences 37(1):130137.

Vinson, M. R., and C. P. Hawkins. 1998. Biodiversity of stream insects: variation at local, basin, and regional scales. Annual Review of Entomology 43:271-293.

Wallace, J. B., S. L. Eggert, and J. R. Webster. 1999. Effects of resource limitation on a detritalbased ecosystem. Ecological Monographs 69(4):409-442.

Webster, J. R., A. P. Covich, J. L. Tank, and T. V. Crockett. 1994. Retention of coarse organic particles in streams in the Appalachian Mountains. Journal of the North American Benthological Society 13(2):140-150.

West Virginia Division of Foresty, 2005. West Virginia silvicultural best management practices for controlling soil erosion and sedimentation from logging operations. WVDOF-TR-053. 


\section{Jered Studinski}

(304) 685-9100

101 East Hillview Drive

jeredstudinski@yahoo.com

Morgantown, WV 26508

Education Ph.D. in Forestry and Natural Resources (in progress), West Virginia University, Morgantown, WV. Expected graduation date: May 2010

Dissertation: The effect of riparian tree harvest intensity on biotic and abiotic stream characteristics.

M.S. in Biology, Western Kentucky University, Bowling Green, KY. August 2005.

Thesis: Environmental factors affecting the distribution of aquatic invertebrates in temporary ponds in Mammoth Cave National Park, Kentucky.

B.S. in Wildlife Management, B.S. in Biology, University of Wisconsin, Stevens Point, Stevens Point, WI. May 2002. Wetlands emphasis.

Experience West Virginia University, Division of Forestry and Natural Resources

Graduate Research Assistant, August 2005-present: I am quantifying the effects of riparian tree harvesting and woody debris additions on aquatic invertebrate communities, terrestrial invertebrate inputs, steam morphology, sedimentation and turbidity, primary productivity, stream temperature, and in-stream salamander abundance. I supervised field crews and lab technicians, and interacted with other graduate students, land managers, and foresters. Advisor: Dr. Kyle Hartman

Instructor, August 2007-present: I volunteered my time to develop and teach Applied Aquatic Entomology (course numbers: 493D, 693H), a 3-credit course open to graduate and undergraduate students during fall. Supervisor: Dr. Kyle Hartman

Teaching Assistant, August 2005-May 2007: I assisted with labs and lectures of courses within the Department of Fisheries and Wildlife. Supervisor: Dr. Kyle Hartman

Western Kentucky University, Department of Biology, Center for Biodiversity Studies

Graduate Research Assistant, August 2003-August 2005: I investigated the factors affecting between-pond and within-pond distribution and abundance of aquatic macroinvertebrates in 10 autumnal pools in Mammoth Cave National Park. Advisor: Dr. Scott Grubbs

Teaching Assistant, August 2003-May 2005: I taught 3-4 sections of labs for Biology 113 and 121 (biology non-majors and majors) and had freedom to develop some course material and all exams. Supervisor: Dr. Cheryl Davis

Field Biologist, May-August 2004: I performed maintenance and restoration duties at the newlyformed Upper Green River Biological Preserve. Most of my activities aided a grassland restoration project. Supervisor: Scott Grubbs

Idaho Fish and Game, Salmon, ID

Crew Leader, Field Biologist, June-August 2003: I conducted snorkel surveys in rivers and streams, tagged steelhead and salmon, and assisted with a bull trout telemetry project. I also operated and maintained a screw trap. Supervisor: Arnie Brimmer 
Experience Wyoming Game and Fish, Casper, WY

(continued) Field Biologist, May-October 2002: I surveyed stream and reservoir fish populations using electroshockers, gill nets, and seines. I also assisted with trout spawning and cutthroat restoration projects throughout the state. Supervisors: Paul Mavrakis and Paul Bailey

USGS Wildlife Research Center, Jamestown, ND

Biological Technician, January 2002: I volunteered during my four-week winter break to sort and identify aquatic invertebrates, weigh specimens, and record data. Supervisor: Bruce Hanson

Public Works Department, Cities of Elkhart and South Bend, IN

Field Biologist, May-August 2001: I was employed to continue a fish index and investigation project within the watersheds surrounding Elkhart and South Bend. Supervisor: Joe Foy

Publications Environmental factors affecting the distribution of aquatic invertebrates in temporary ponds in Mammoth Cave National Park, Kentucky, USA. Studinski, J.M. and S.A. Grubbs. Hydrobiologia (2007) 575:211-220

Awards Dissertation fellowship (WVU) 2009

West Virginia University Distinguished Doctoral Fellowship (WVU) 2008

Kevin Kinsley Outstanding Graduate Student in the Division of Forestry (WVU) 2007

Outstanding Graduate Teaching Assistant (WKU) 2005

Memberships American Fisheries Society (AFS)

West Virginia University chapter of AFS, elected webmaster (www.wvu.edu/ wvuafs)

Presentations AFS Annual Meeting, 2009, Nashville, TN: Influence of riparian forest manipulations on habitat and food sources of brook trout. Oral.

AFS Annual Meeting, 2008, Ottawa, ON: Influence of riparian forest cover manipulation on terrestrial invertebrate inputs into headwater streams. Oral.

Southern Division of the AFS Spring Meeting, 2008, Wheeling, WV: Influence of riparian forest cover manipulations on terrestrial invertebrate inputs into headwater streams. Oral.

Southern Division of the AFS Student Colloquium, 2007, Charleston, WV: The effects of logging and large woody debris addition on stream morphology. Oral.

Southeastern Association of Fish and Wildlife Agencies (SEAFWA), 2007, Charleston, WV: The effects of logging and large woody debris addition on stream morphology. Oral.

North American Benthological Society (NABS), 2005, New Orleans, LA: Factors affecting macroinvertebrate assemblages in autumnal wetlands at Mammoth Cave National Park, Kentucky. Poster.

Kentucky Academy of Science, 2004, Murray, KY: Factors affecting aquatic macroinvertebrate abundance and richness in forested temporary wetlands. Oral. 